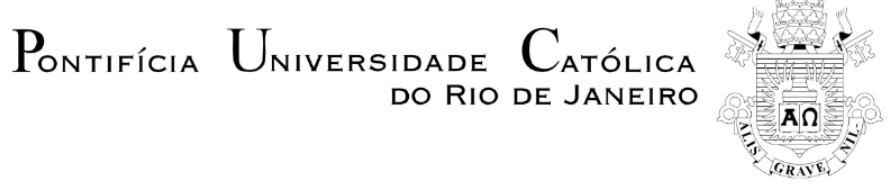

Renato Sabbagh Bahia

\title{
Genocide and its Political use: a Conceptual History
}

\section{Dissertação de Mestrado}

Dissertation presented to the Programa de Pós-graduação em Relações Internacionais do Instituto de Relações Internacionais of PUCRio in partial fulfillment of the requirements for the degree of Mestre em Relações Internacionais

Advisor: Prof. Paulo Luiz Moreaux Lavigne Esteves 


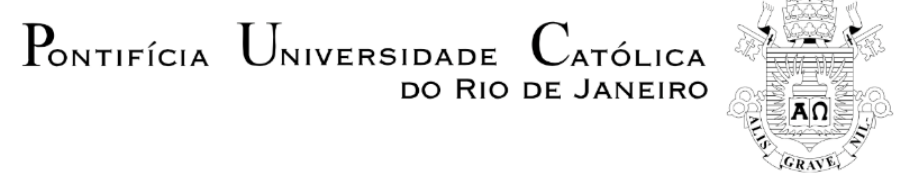

Renato Sabbagh Bahia

\title{
Genocide and its Political use:
}

a Conceptual History

Dissertation presented to the Programa de Pós-graduação em Relações Internacionais do Instituto de Relações Internacionais of PUCRio in partial fulfillment of the requirements for the degree of Mestre em Relações Internacionais. Approved by the undersigned Examination Committee

\author{
Prof. Paulo Luiz Moreaux L. Esteves \\ Advisor \\ Instituto de Relações Internacionais - PUC-Rio \\ Prof. Mônica Herz \\ Instituto de Relações Internacionais - PUC-Rio \\ Prof. Maurício Barreto Alvarez Parada \\ Departamento de História - PUC-Rio \\ Prof. Mônica Herz \\ Vice Dean of Graduate Studies \\ Centro de Ciências Sociais - PUC-Rio
}


All rights reserved.

\section{Renato Sabbagh Bahia}

The author graduated in International Relations from Pontifícia

Universidade Católica do Rio de Janeiro (PUC-Rio) in 2014.

Bibliographic Data

Bahia, Renato Sabbagh

Genocide and its political use : a conceptual history / Renato Sabbagh Bahia ; advisor: Paulo Luiz Moreaux Lavigne Esteves. -2017. 132 f. ; $30 \mathrm{~cm}$

Dissertação (mestrado)-Pontifícia Universidade Católica do Rio de Janeiro, Instituto de Relações Internacionais, 2017.

Inclui bibliografia

1. Relações Internacionais - Teses. 2. Genocídio. 3. História dos conceitos. 4. Raphael Lemkin. 5. Direito Internacional. 6. Tribunal Internacional Militar de Nuremberg. I. Esteves, Paulo Luiz Moreaux Lavigne. II. Pontifícia Universidade Católica do Rio de Janeiro. Instituto de Relações Internacionais. III. Título.

CDD: 327 


\section{Acknowledgements}

To my parents, Ismail and Christina, who have been the basis of possibility for not only this work, but mostly all my professional and personal projects. To my brother, Marcelo, who inspires me with all his discipline and dedication. Without these three my paths in life might not have been the same. All your patience and understanding throughout these last few months of dissertation-writing were invaluable.

My advisor, professor Paulo Esteves, I thank for his eternal patience and careful Reading, and whose suggestions were critical for the completion of this work in the best way possible. To my professors who, to a lesser or higher degree, contributed in a positive manner to this dissertation, be it through debates in class, through commenting chapter drafts or the articulation of certain arguments and ideas - in class or otherwise -, being worth citing, in no particular order, professor Roberto Yamato, Maurício Parada, Mônica Herz, Jimmy Casas Klausen, Isabel de Siqueira, Bruno Magalhães, Raslan Ibrahim and Victor Coutinho.

To Geisa and Lia who bore with me with endless patience and care.

To my professor and friend, Danilo Marcondes de Souza Neto, whose presence in my academic life since 2011 has been invaluable to my professional growth. Also professors Paula Drumond and Fernanda Alves, my eternal gratitude for being the two from whom I took to love my research field. To professor Fernando Maia, whose critical talk in 2014 was the igniting spark to this work.

To Inez, who helped me to drastically change - for the better - my life in almost every way. Marina and Thais, who suddenly and inexplicably joined my life in early 2010 and have been, since then, my own guardian angels.

To my Master's degree class, who constantly and positively surprised me throughout the past two years, be it through our mutual support in class, on a personal level or even through the writing processes of our dissertations. Lucas, the tireless discussant, who made the commute not only easier, but academically productive through his insights. You are one whose friendship I hope to maintain not only through the halls of academia, but through life itself. Amanda, Natasha and Mayra, I surely did not deserve the dedication and care that I received from you. Luisa and Beatriz, my partners in crime in PUC's Library, those long hours were made incredibly lighter with your presence.

To my friends from a certain neighborhood that kept me sane during Brazil's recent political turbulences.

Last, but not least, to CAPES whose financial support made this work possible. 


\section{Abstract}

Bahia, Renato Sabbagh; Esteves, Paulo Luiz Moreaux Lavigne (Advisor). Genocide and its Political use: a Conceptual History. Rio de Janeiro, 2017. 132p. Dissertação de Mestrado - Instituto de Relações Internacionais, Pontifícia Universidade Católica do Rio de Janeiro

This work seeks to investigate a few of the conditions of possibility for a concept of Genocide. By establishing an analysis that tries to reconcile the basis under which the creation of the concept in 1944, as well as its reception, take and dispute of what the concept must (have) mean(t) between 1944 and December 1948, when the Convention on the Prevention and Punishment of the Crime of Genocide was approved by the United Nations General Assembly, this work aims for an understanding of a few of the political and social limits on the employment of the term "Genocide". More than just considering the politicisation ("Politisierung"), it is argued that a certain understanding of what "Genocide" "is" or "ought to be", be it through the proposed temporal frame or through the debates that follow in the Field of Genocide Studies, requires an approach that reflects on the multiple temporalities that each claim for a certain meaning that is brought within the Concept.

\section{Keywords}

Genocide; Conceptual History; Raphael Lemkin; International Law; Nuremberg Trials 


\section{Resumo}

Bahia, Renato Sabbagh; Esteves, Paulo Luiz Moreaux Lavigne. Genocídio e seu uso político: uma história conceitual. Rio de Janeiro, 2017. 132p. Dissertação de Mestrado - Instituto de Relações Internacionais, Pontifícia Universidade Católica do Rio de Janeiro

O presente trabalho propõe uma investigação de algumas das condições de possibilidade quanto ao conceito de Genocídio. Buscando entender alguns dos limites políticos e sociais na utilização do termo "Genocídio" - no Internacional ou não -, estabelece-se uma análise que tenta conciliar as bases que tornam possível a invenção do conceito em 1944 pelo jurista polonês Raphael Lemkin, bem como sua recepção, abordagem, e disputas quanto ao que o conceito deve(ria) significar entre 1944 e dezembro de 1948, quando a Convenção para a Prevenção e a Repressão do Crime de Genocídio foi aprovada pela Assembleia Geral das Nações Unidas. Mais do que apenas determinar a politização ("Politisierung") do Conceito, argumenta-se que um entendimento sobre o que "Genocídio" “é” ou "deveria ser", seja no recorte temporal proposto, seja nos debates que se seguem no Campo de Estudos sobre Genocídio, requer uma abordagem que reflita as múltiplas temporalidades que cada reinvindicação de significado do Conceito traz em si.

\section{Palavras-Chave}

Genocídio; História dos Conceitos; Raphael Lemkin; Direito Internacional; Tribunal Internacional Militar de Nuremberg 


\section{Table of Contents}

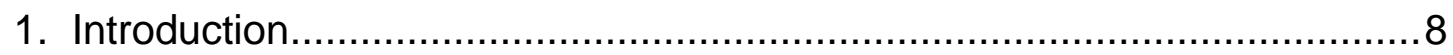

2. On the Problem of Genocide and Conceptual History ...........................14

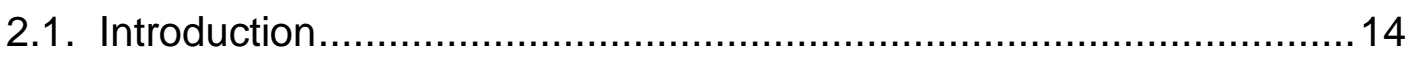

2.2. Contextualising the Field of Genocide Studies ............................... 16

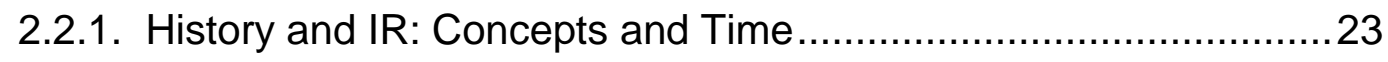

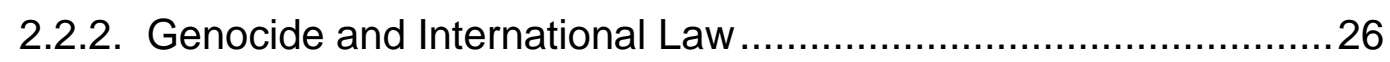

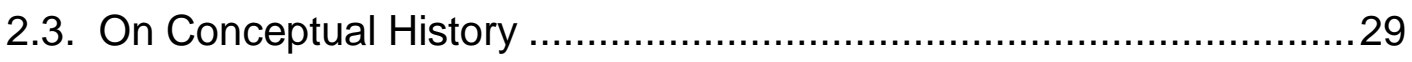

3. Genocide before Genocide: Raphael Lemkin, Barbarism and

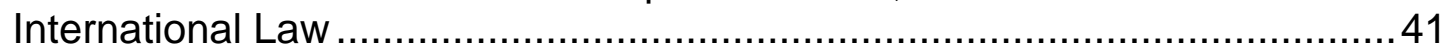

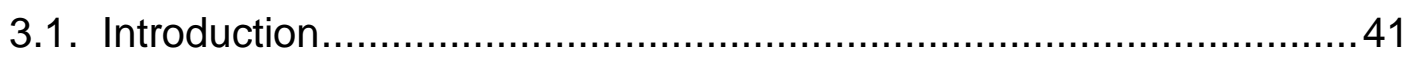

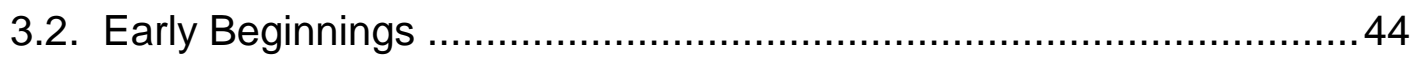

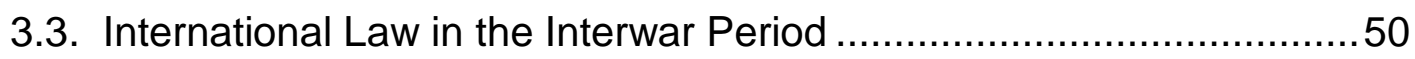

3.4. From "Barbarism" and "Vandalism" to the United States ...................58

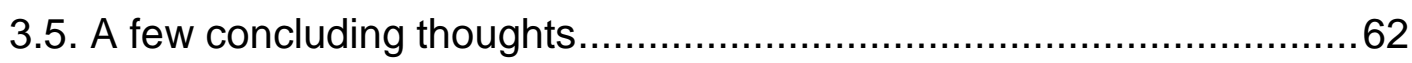

4. Genocide from Axis Rule in Occupied Europe to the Convention ............64

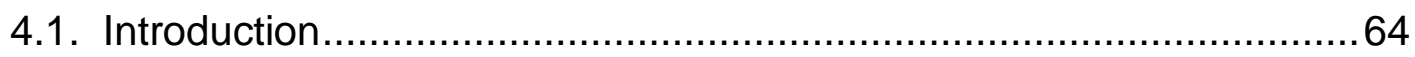

4.2. On the perceptions of the Holocaust viz a viz Genocide ...................65

4.3. On the reception of Axis Rule and the London Charter .....................75

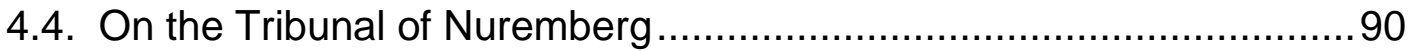

4.5. Genocide at the UN: The road to the Convention............................97

4.6. The Three Drafts and the Convention .........................................100

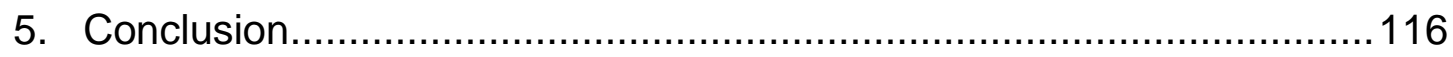

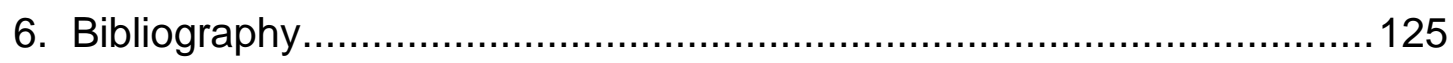




\section{1. Introduction}

This research main goal is to build up a Conceptual History of "Genocide". It seeks to come to terms with not only the idea of what "Genocide" is supposed to be, but how the concept itself was - and in a certain way has since then been - disputed between several actors within International Politics between 1944 and 1948. As such, it is possible to identify two main axis around which the present research revolves around. Two axis with different weights, that is true, but two nevertheless: the historiographical and hermeneutical debate surrounding not only the possibility of 'doing' a conceptual history and, perhaps more importantly, an attempt to cope with a few of the difficulties surrounding the Field of Genocide Studies. I'm referring, here, to the perceived opposition within the academic approach towards 'Genocide' and an 'applied Genocide prevention' approach (Bauman, 1989, p.15; Hinton, 2012, p.5).

In other words, I seek to deploy Conceptual History (Begriffsgeschichte) as a framework upon which I'll try to understand the political dispute surrounding the concept of "Genocide", particularly in terms of its perceived origins between 1944 and 1948. That is, between Raphael Lemkin's famous formulation of "Genocide" within the publication of "Axis Rule in Occupied Europe" (Lemkin, 2008) and the various instances upon which different shades of meaning had been added - or removed - from the (many possibilities of a) concept of Genocide by certain actors within the International Arena until its institutionalisation: within the Nuremberg Trials, the United Nations General Assembly (UNGA), the Economic and Social Council of the United Nations (ECOSOC) and the many sub-committees until the approval of the Convention on the Prevention and Punishment of the Crime of Genocide of 1948. My proposal, then, can be seen as an attempt to come to terms with the early discussions towards what the idea of "Genocide" was supposed to represent. Not necessarily to put a closure on the debate of Genocide - for I do not believe that to be neither useful nor possible anyway - but to understand the limits and possibilities of what "Genocide", as a concept, can, or cannot, should or should not, represent. That is, the very borders and boundaries of what the idea of Genocide may or may not 
cover, what kind of possible histories may be understood, can be made sense from a certain idea of "Genocide".

In essence, I'm pondering around questions such as "What 'Genocide', as a concept, is supposed to mean?'. That is, considering the relationship between hermeneutics and phenomena, between language and events (Koselleck, 1989), what is usually meant, what do we make reference to, when we invoke the concepts(s) of 'Genocide'?. Or, better yet, what is possible for us to mean when one makes reference to something as "Genocide" or as something else entirely? This question begs more seriousness than it might appear. After all, there seems to be a cleavage in terms of how the concept is dealt with between the diplomatic practice and scholarship in general. This can be shown by a brief comparison between Scott Straus (2001, p.349), who identifies about 21 different ways to define and conceptualise "Genocide" and Schabas (2008, p.47) who argues that the concept of Genocide, in diplomatic usage and terminology, has not altered significantly since the 1948 convention.

Both Schabas (2008) and Straus (2001) make a very compelling point. While the former argues that "The legal certainty that this codification [The Genocide Convention] accomplished no doubt contributed to the stability of the definition [of 'Genocide'] over the ensuing six decades" (Schabas, 2008, p.46), the latter states that "despite an abundance of excellent scholarship on definitions, genocide remains a deeply contested concept" (Straus, 2001, p.349).

To explore a few of the limits of this relationship between possibilities for contesting and/or stabilising a certain understanding of what 'Genocide' must be and what it cannot, possibly, become can be seen as the main point of this work. Just as any attempt to make sense of what a perceived reality - or a reading of what one might understand to be a sort of 'reality', to be fair -, to name an event, or to read an event, as 'Genocide' carries within itself deep, polemical, political consequences: for victims, perpetrators, would-be intervenor's, to name a few of the common actors of a genocidal instance.

Finally, with this context in mind, my objective here is to attempt to bring into light the conceptual dispute surrounding the possibilities of interpretation, of narrative, of memory even of, what "Genocide" was supposed to mean between 1944 and 
1948 as a way to consider the conflictive, controversial, nature of the concept of "Genocide" despite many attempts of not only to linguistically stabilise a series of events that may be inherently shocking to modern society ${ }^{1}$ but also as an attempt to project further into the future what "Genocide", as an event to-come - and to be prevented - should "look like".

"Genocide", thus, is a word, a concept, that carries tremendous social weight. To claim something, 'some event, some series of events, a cataract of events' (Koselleck, 1989 , p.652) as Genocide is to claim, politically, what a few might understand to be the ultimate form of violence, of inequality, of injustice, of destruction, that a State $^{2}$, an institution already violent, unequal and unjust - however one may take these concepts to represent - which calls, demands, some sort of action be it by the International Community or specific domestic actors. We need not to go far to keep examples in mind: consider, for instance, the 2005 World Summit Report ${ }^{3}$ which considers protection against Genocide - along with war crimes, ethnic cleansing and crimes against humanity - as one of the main duties of the International Community. Or, to strike an argument closer to home - quite literally, in this case - the claims and denouncements of ongoing Genocide in Brazil against its own black population, which even if it is a claim that has been circulating since at least the 1970 's ${ }^{4}$, it started to get traction in larger audiences most recently through a Comissão Parlamentar de Inquérito ${ }^{5}$ (CPI) in the Brazilian Senate, in 2015, set to investigate a heavy bias - if not outright genocide, as part of the argument goes - against black, poor, youngsters in the rate of murders - conducted by the police or not - in the past decades.

The debates concerning both situations - interventions in International Politics, political struggles for redress against, to say the least, inequality and abuse, or Genocide, to say the most - one way or another ends up taking part on the larger framework, on the larger conditions of possibility to what it means to state something as a Genocide or as something else entirely. It represents the stakes within the category,

\footnotetext{
${ }^{1}$ Despite, as has been argued before by a plethora of scholars and will be reinforced in this work, the intrinsic relationship between Modernity itself and Genocide

${ }^{2}$ Though, admittedly, there is room for the argument that a State per se is not a required condition for a Genocide to happen.

${ }^{3} \mathrm{~A} / \mathrm{RES} / 60 / 1$

${ }^{4}$ Cf. Nascimento, 1978

${ }^{5}$ Roughly translated as 'Congressional Commission of Inquiry'
} 
true, but it also reflects too familiar questions that, one way or another, may constitute certain traces of what one might associate with Genocide, that is, with a proper semantical field that revolves around the concept. Thus, we might be facing questions of intent, of what kind of destruction is needed - of people? Of goods? Religious and cultural customs? Political affiliation? And so on - and in what quantity - that is, the dreadfully cynical question of 'how many bodies constitute a Genocide?'. In short, both scenarios are part of the very linguistic possibilities, with its novelties and recurrences, that partakes what it means to state something as Genocide.

Thus, this research aims to re-evaluate the current field of Genocide Studies, especially how it has been dealing with a certain concept of Genocide, through an analysis of the temporality within certain manifestations of the concept. If each enunciation contains in itself certain claims to what has already passed, that is, as forms of reading past events, instances, circumstances, through "Genocide", it also contains certain claims towards what "Genocide" can, or should, be, that is, what kind of patterns of events, signals, actions can - or ought to - be seen through the prism of Genocide so as to allow certain forms of prevention and, ultimately if needed, punishment.

If we have claimed to undertake a conceptual history of Genocide, this means, mostly, a take on the concept that considers its own temporalities, its own space of experiences and horizon of expectations that allow us to frame certain conditions of possibility of what the concept can, or cannot, represent. We are facing, thus, certain possible boundaries in terms of the debate of what Genocide "is" within the field of Genocide Studies. Such boundaries, so our argument here goes, can be appreciated through a revisit of the 'origins' of the debates, the political disputes towards "Genocide" at its roots: through Lemkin's Axis Rule in Occupied Europe (Lemkin, 2008), published in 1944, its reception in the general media and scholarly community in 1944 and 1945, its use and, arguably, misuse in the Nuremberg Trials, and finally the struggles for a Genocide Convention within the United Nations, between 1946 and 1948. Each enunciation of the concept in each circumstance, so our argument goes, denotes certain boundaries of what the Concept can or cannot cover or, perhaps, consider; that is, what kind of events 'best' represents what the Concept is supposed to give meaning to, or, even, what kind of future events might be allowed to be consid- 
ered under the wings of the Genocide Convention, and what might represent something else entirely.

The first chapter is an effort of presenting my take on "Begriffsgeschichte" conceptual history - as not only a Theory of History per se, but also a proper Theory of Time that takes into consideration multiple temporalities. The claim, here, in part would be that a certain space of experiences/horizon of expectations may help us to understand what "Genocide" "is" each time it is announced. It is also in this chapter that we may better appreciate the possibilities for using these as historical categories that helps make sense of certain political disputes towards not only "Genocide", but modern, political concepts in general. More than that, the chapter will also present a few of the current debates within the Field of Genocide Studies so as to make it conceptually clear what I mean when considering the problem of politicisation of the concept of Genocide.

The second chapter will deal with a certain space of experience/horizon of expectations that might have laid down the basis upon which to consider "Genocide" as a linguistic innovation of sorts with the goal of understanding, describing, certain kinds of events that might not have had a proper concept to make sense of them. That is, if the concept appeared for the first time in Raphael Lemkin's Axis Rule in Occupied Europe, there still remains questions that relates to the why, the when, and the how so: that is, it is necessary to assume that the concept did not magically appeared as if divine inspiration had inflicted Lemkin. "Genocide" was not a fiat ${ }^{6}$. Thus, this chapter will direct itself towards the conditions that might have made "Genocide" possible in 1944: it will accompany Lemkin's journey from an infancy troubled with antisemitism in Imperial Russia, a somewhat difficult carer in also anti-Semitic pre-world war II Poland, his flight from Nazism and his somewhat contentious relationship with a certain spirit that permeated what International Law might have thought of itself in the 1920's and 1930's.

Chapter 3 will direct towards the Concept of Genocide per se, that is, how it was employed and perceived within Axis Rule in Occupied Europe, within the general press, especially considering editorial articles from the American media, within the

${ }^{6}$ A reference towards the Latin translation of the early passages of the Genesis (1:3) "dixitque Deus fiat lux et facta est lux" or, roughly, "and said God let there be light, and light was made" 
academy in general, taking into consideration the plentiful reviews under which the book was targeted, and, finally, the framing of the concept within the Nuremberg Trials. It will also consider not only Lemkin's action throughout the UN debate on the topic, and how it was conducted separately by the various committees under which the many drafts, and the final version, of the Genocide Convention circulated, that is, from the UN General Assembly, the UNGA Sixth Legal Committee, the ECOSOC and its various ad hoc committees.

Our conclusion, thus, will direct us to consider not only how, in general terms, each utterance of "Genocide" might have related to what kind of future and past events, but also how, following a layered, multi-temporal consideration of Concepts, each past and future use represents some sorts of limits and possibilities in terms of what the "Genocide" might be: what, in short, might be considered valid under the Genocide label and what may not, that is, what might be the very conditions of possibility that might allow us to consider what might be the central matter of a good part, if not entirely, of the Field of Genocide Studies. 


\section{2. On the Problem of Genocide and Conceptual History 2.1. Introduction}

The general goal of this chapter will be to establish a few intricacies of Begriffsgeschichte (Conceptual History) in relation to the more specific objectives of this work in general. If we seek to deploy Conceptual History as a framework upon which we can understand the political dispute surrounding the concept of "Genocide" in its perceived origins between 1944 and 1948, then there is a need for us to establish, first, what we mean by "Conceptual History" and how it may be, indeed, useful for us.

The argument here will unfold in a few directions. The first goal relates to a few of the current conundrums of the theoretical framework that guides a good deal of the Field of Genocide Studies. As Shaw (2015, p.5) rightly suggests, to ask 'what Genocide is' is tantamount to ask 'what Genocide should mean', which, for its part, requires a question that relates both towards who is asking and who is attempting to give an answer. To claim, in this instance, that it is an inherently political problem with difficult consequences (Shaw, 2015, p.22) is a good starting point. What, however, does it mean to name 'Genocide' an inherently political problem? If one asks a sociologist, like Shaw, it means stating that it relates to attempts and claims to define what the label 'Genocide' stands for, and as such, what - and when - some kind of action is deemed necessary or irrelevant. Ask a historian, a lawyer, a politician, victims and perhaps even perpetrators and we might have different answers.

Examples are certainly abundant. One might make reference, here, to the most common - 'canonical', even - instances of Genocide citing the Armenians, the Holocaust, Cambodia, Rwanda and Bosnia (Hinton, 2012, p.13), or, perhaps, one might consider Shaw's (2013, p.86-97) analysis which puts in perspective the then ongoing genocidal processes in the late 1940's - the USSR 'reorganisation' of Eastern Europe and its own internal dissidents; the Chinese Civil War, the brutal border clashes between the emerging States of India and Pakistan, each with the direct or indirect participation/complicity of a major power involved in the discussion of what 'Genocide', 
as a category, ought to represent. In short, our first section will be an attempt to frame what one might mean by a politicisation of the concept of Genocide. That is, how different forms, possibilities, definitions of what Genocide might mean, or at least, what it ought to mean, not only relates - accepting, refuting, ignoring - to each other, but also how claims for a definition of Genocide relates to certain perceptions of a reality of sorts, a specific sort of events, and, more importantly, the very temporality of each enunciation. By presenting a few of the main contentiousness of the field of Genocide Studies we will be able to better appreciate the kind of puzzle we are facing - and proposing - when considering the possibilities of what "Genocide" might mean between 1944 and 1948. Then, we will explore the issue of Genocide in two other angles: first in light of International Relations as a discipline, that is, on how our questions relating to history, temporality, events, structures and, in a certain way, possibilities for conceptualization may insert themselves in disciplinary International Relations. The cue would be that a few of the present puzzles are not at all far away from common dilemmas that the typical IR researcher has to face. The second explores the contentious relationship between International Relations and International Law. Or, in other words, we will briefly explore the intersection between events and their readings, and their codification through Law. While the case of Genocide and International Law, especially when "Genocide" was "not yet Genocide", is more deeply considered in our second chapter, this is might represent a good starting point on the matter.

Then, the chapter will briefly present what one might understand "Conceptual History" to be, that is, more than just portraying it as a method per se but as a Theory of multiple (layered) temporalities (Jordheim, 2012). Thus the basis for a claim to temporalizing the very politicisation ("politisierung") of the concept of "Genocide" through framing it in multiple temporal layers, which might be another way of arguing for an understanding of what the limits of each - unique - utterance of "Genocide" might be, that is, how each claim towards "Genocide" can be temporally understood as a certain reading of a past event and a specific possibility for prediction - prevention, punishment - of how, when, where one might identify something as "Genocide". 
Following this discussion we'll attempt to clarify the role of "Concepts" in a "Conceptual History", i.e. how the relationship between - some sort of - reality is dealt with language per se. How words, concepts, and language relates, enabling and constraining, to not only the historians metier but, as might be safely argued, the different enterprises in social sciences in general. Having in mind Ifversen (2011), we might as well pose the problem in terms of how concepts are situated in Language and, ultimately, in time. The point of this discussion might be indicated as few suggestions on common difficulties inherent to the process of a 'conceptual history'. More specifically I hope to lay the bases upon which one might start to question and ponder upon the possibility for a 'conceptual history of Genocide'

\section{2.}

\section{Contextualising the Field of Genocide Studies}

The field of Genocide Studies began to take shape - or so the story is told - in the 1980's, with the publication of many works that are deemed classical within the field. To name a few, we can cite Irving Horowitz's Taking Lives: Genocide and State Power (Horowitz, 1980), Leo Kuper's Genocide: its political use in the Twentieth Century (Kuper, 1981), Israel Charny's How can we commit the unthinkable: Genocide, the human cancer (Charny, 1982) (Totten \& Jacobs, 2002, p.xi). As any academic field that acquires a certain age, the last few years have seen the appearance of what is usually understood as "Critical Genocide Studies" which can be roughly understood as efforts to 'take a step back' and revaluate what the field has done in the past three to four decades, where it's main issues lay and how to address them (Hinton, 2012; Moses, 2004). In this light for the next few pages we'll turn towards an evaluation of the field of Genocide Studies. It would be impossible, otherwise, for us to justify our methodological and analytical choices within this work.

Alexander Hinton (2012), through his attempt to what he calls 'decentring the field', establishes a cut within the discipline, between what he calls "Genocide Prevention" and "Critical Genocide Studies" (Hinton, 2012, p.5). This is a division, as the argument goes, that reflects not only the moral imperatives that guides the field, but what is usually taken to be how the founding father of the concept of Genocide, Raphael Lemkin, used to operate. That is, within the tension between an academically 
informed scholar that is also a politically committed activist. This spirit, for instance, is strongly captured by the current International Association of Genocide Scholars (IAGS), created in 1995 under the name of "Association of Genocide Scholars" (Hinton, 2012, p.5-6).

Through these we can start pinpointing a few of the issues that permeates the field, issues that could be argued to be congenitally born within the field. If the field established itself in the 1980's and the following decades, it was a relatively direct offspring of the "Holocaust Studies" discipline, which was born in the late 60's and 70’s (Bloxham \& Moses, 2010, p.3).

There is an important temporal gap here that we must address. Our temporal frame relates to the initial disputes towards a definition of Genocide between 1944 and 1948. At the same time, it is also claimed that the Field of Genocide Studies emerged in the 1980's from a certain split of the Holocaust Studies field that was born in the 1960's. The "why so long?" question is a relatively common one, and a crucial question at that (Hinton, 2012, p.6; Totten \& Jacobs, 2002, p.xi).

This raises a series of questions towards the role of the Holocaust within Genocide Studies, and at least as many answers. Hinton (2012, p.6) suggests that there are certainly key events and contexts that offer possible answers to this issue. First of all, the Holocaust itself as an event with enough power to force the hand of most politicians and diplomats in its aftermath. Mostly, true, through the $\mathrm{UNCG}^{7}$, which may lead a few authors to prefer it to the Holocaust as the pivotal event towards the creation of the Field of Genocide Studies, a proposition Hinton disagrees (Hinton, 2012, p.7). If, as the author seems to prefer, we adopt the Holocaust as a landmark, then we have to deal with a whole range of other issues.

This context makes it necessary for us to take seriously the contention between Holocaust Studies and the Field of Genocide Studies. The former was formed mostly from a few events in the 1960's, such as the Eichmann Trial in Jerusalem in 1961, the Auschwitz trials in Germany between 1963 and 1965 and Hannah Arendt's publication of "Eichmann in Jerusalem" in 1963 (Hinton, 2012, p.7). It is possible to argue, in this light, that the Field of Genocide Studies came to be from scholarly dis-

\footnotetext{
${ }^{7}$ United Nations Convention on the Prevention and Punishment of the Crime of Genocide
} 
satisfaction towards a few positions of Holocaust Studies: the reference, here, is towards the debate on the uniqueness or the possibility of establishing comparative studies of Genocide (Bloxham \& Moses, 2010, p.4).

What seems to be at stake here is a crucial matter for our objectives: it relates directly to the contentious relationship between a certain event and the possibility of building a certain narrative of it through the articulation of concepts: that is, through the deployment of the "genocide label" within a certain number of cases of mass violence (Shaw, 2013, p.21). The labelling of Genocide has everything to do with the idea of Politicisation ("Politisierung") of Modern Concepts as indicated by Koselleck \& Richter (2011, p.15), while also relates to Kelly’s (2008, p.148) argument that labelling something as "Genocide" has strong political consequences, a move that is made possible through, mostly but not exclusively, the imperative behind the label itself: the necessity of prevention and punishment.

In other words:

Indeed the politics of every subsequent genocidal crisis, from Rwanda to Darfur, have revolved considerably around the tension between demands for and refusals of the 'genocide' label, understood largely as the acceptance or denial of Holocaust bridging. (Shaw, 2013, p.21)

As Shaw (2013, p.22) indicates, this is an inherently political problem with difficult consequences, for there is always the possibility that one group's victimization experience may be traded against another's in a competitive political struggle, which could lead either to contentious searches for the right historical analogy or to even denial of certain Genocides.

It might be possible to suggest that this is what is behind most of the presentdebate on the uniqueness or the possibility of establishing comparisons of the Holocaust with other cases. One could present, for instance, the Holocaust political appropriation both by a few Israeli advocates and Palestinian claims towards their own treatment by the Israeli Government (Shaw, 2013, p.22). If we have indicated the process of instrumentalization of concepts - and thus of certain narratives behind certain categories of events -, this as good as any indicator of what's at stake within these processes. 
Another way of considering the issue would be within the "functionalists versus intentionalists" debate, as Donald Bloxham (2009, p.314) puts it. If we are looking for general - and perhaps more interesting - questions behind this debate it would be the structural-agency debate that so dominated social and political sciences in the 60's and 70's. We might as well, however, consider these issues within History and Historiography, that is, in terms of events, as singular entities, and the structures that may or may not condition them.

The 'intentionalists' approach is more broadly conceived within the assumption of "consistent Hitlerian desire for genocide well before the killing began" (Bloxham, 2009, p.305), while the 'functionalists' may be identified as those with the desire for "compiling deep empirical accounts of it [the Third Reich], its institutions, and its policies" (Bloxham, 2009, p.307). The point here, nevertheless, is to consider - at least partially - how the Holocaust-Genocide relationship has been dealt with, alongside its implications for the field of Genocide Studies, something that we can start to glimpse within this context.

These debates led, within the historiography, a more important - at least for our purposes - exchange in terms of the 'uniqueness' of the Holocaust versus the possibility of its comparison with other cases of Genocide. It was an easy evolution from the intentionalist approach to a certain reluctance to examine the Holocaust in light of other genocides. It is an understandable and relatively fair point: it follows from not only the identitarian politics within Jewish traditions, but also from the need for memory and trauma redress. It could be fairly indicated, too, that the point was also akin to an understanding that a structuralist interpretation did not do justice to the magnitude or even to the shades of meaning that an event such as the Shoah could have had/has been having within not only the survivors but also to their communities (Bloxham, 2009, p.315).

This is not only a very contentious issue, but one that directly relates to what we're trying to do here. Is the disentanglement between "Holocaust" and "Genocide" possible, or even desirable? "Possible", here, in the sense that the very wording of 'Genocide' has been articulated through the Holocaust process thanks to Lemkin's (Lemkin, 2008) work. It is a reference to that event, it tries to capture it, and, most of 
all, it expands and sweeps it into both future and past. As a modern concept, it has a certain degree of Temporalization ("Verzeitlichung"): that is, it indicates the possibility of acquiring new experiences through a certain temporal dimension within the categories of meaning of a certain concept (Koselleck \& Richter, 2011, p.9). The Genocide definition within Lemkin (2008) is nothing but one chapter of roughly thirty pages on a more than seven hundred pages book. The rest of it is dedicated to describe the methods through which the Nazi administrated, ruled and conducted its process of Genocide, of extermination of certain undesirable groups. It seeks to empirically show how $a$ process of Genocide might occur, and possibly could be understood as way of trying to push towards the punishment of perpetrators. We may, in this light, be able to re-read the Holocaust - as the continuing studies of the Holocaust has been doing since the 60's.

Genocide is the Holocaust; the Holocaust is Genocide and they are both much more than each other. To argue for the 'conceptual purity of Genocide' is a very contentious claim. Or, at least, as contentious as simply instrumentalising the concept for one's own purposes. This first process of essentialisation can be understood through Hinton's (2012, p.10) “dilution metaphor”, which can be roughly understood as a gate-keeper mechanism that works to affirm the primacy of certain cases, of certain groups, of certain victims towards another.

We can pinpoint a few strands of criticism towards this context. We might follow Bauman's (1989) steps when considering the role of the Holocaust within the Genocide Studies/Holocaust studies debate. That is, we ought to consider the inherent problems of essentialising the uniqueness role of the Holocaust in a sociological/analytical perspective. The Holocaust could be understood as unique and relating to Jewish history in particular, which would render the topic "sociologically inconsequential" (Bauman, 1989, p.1), that is, a one-off episode. Or, perhaps, it could be understood as an extreme case of a wide and yet relatively familiar case of social phenomena, one that relates closely to a certain idea of a natural predisposition of the human species and the case for civilisation being the possibility of holding this nature back (Bauman, 1989, p.2). Or outright a uniquely horrifying, yet "fully logical" consequence of ethnic and religious hatred (Bauman, 1989, p.2). 
In any case, as the argument goes, "the bomb is defused". A 'solution' to the problem can only be presented in terms of a search for a better technology for practises of social engineering - that is, of controlling society's individuals in a manner of bringing forth 'the good'(Bauman, 1989, p.3). Simply put the message is clear: the Holocaust would be seen as a failure of modernity and not its own product (Bauman, 1989, p.4). The author's point is relatively direct: The Holocaust should be understood as not only a product of modernity, but a possibility within it - which is different to say that it is 'the truth' of modernity, or that it is all there is to it. Civilisation and Genocide ought to be taken as two sides of the same coin called 'Modernity' (Bauman, 1989, p.5).

We may take this cue to bring about an extremely important point within Bloxham's (2009) book: the origins of (one possible among others) narratives towards the uniqueness of Genocide that Bauman's work did not pursue despite his argument towards linking Genocide and Modernity. The Holocaust might be argued to be unique to its victims for very obvious reasons, but it certainly was not the first stance of mass murder that can be linked with the idea of Genocide in western history, perpetrated by westerns or not, in the last 200 years. In other words, the question would be in the lines of "why the Holocaust might be considered unique within Western audiences that were not their victims?".

Bauman (1989) partially answers it when associating with western modernity, true. Weitz (2003) presents another important step by linking it with a certain dose of utopianism ${ }^{8}$ and revolutionism, albeit a very restrict - if not outright misleading reading at that. The point is driven home, however, by Bloxham (2009) with the argument that other genocides have been of insufficient interest to Western intellectuals precisely because, as an event that occurred in the heart of western modern civilisation, it carries within it a certain dose of 'surprise', of shock, that western intellectuals and society could not sidestep from - cynical or not - interpretations or narratives as they have been doing in justifying their own colonial policies, to name one example ${ }^{9}$.

\footnotetext{
${ }^{8}$ This notion of Utopianism should not be confused, strictly, with what most proponents of the uniqueness of Nazi Holocaust mean when they also summon "utopia" as a reason for the Holocaust

${ }^{9}$ At this point it might be inevitable to make reference to Césaire's (1972) important argument towards the relationship between colonialism and Nazi atrocities.
} 
This is a dimension that can - and will - be explored into further details once we get a grip of the historical categories of experience/expectation within Koselleck's (2004) framework.

On this note, we might as well start to consider another dimension within the Field of Genocide Studies: the focus on comparative studies. There are important methodological and political issues to be addressed here. Politically, we may follow on Hinton's suggestion of (resistance towards a) canonisation of the field case studies, citing 'the triad - Rwanda, the Holocaust and Armenian Genocides -, The 20/21th Century Core - all of the already cited plus Bosnia, Cambodia, Darfur -, a 'Second Circle', which adds East Pakistan, the Kurds, Guatemala, Herero/Namibian, Kosovo, Ukrainian/Soviet genocides, a "Periphery" of even more contested cases and then the so called 'Forgotten Genocides', that is, cases which are typically not even brought up for discussion (Hinton, 2012, p.13).

As much as Hinton (2012) is very vocal - and perhaps rightly so - towards his criticism of having a core of cases which typically leads to a somewhat more restrict/bounded notion of what Genocide might entail. It is also representative of the force behind the 'Comparative Case Studies' ethos within the Field of Genocide Studies. Politically the stakes are what Martin Shaw (2013) and many others have already been claiming: defining Genocide is a political business. In terms of Methodology, however, it means a search for general attributes which might permit us to recognise when and where a Genocide - as a certain category of Event - is occurring, or at least has occurred, or, ideally, when it will occur - so as to allow the possibility of prevention. Perhaps this is more about the, alas somewhat cynical, claim of 'Never Again!', that is: the need for prevention and punishment that are invoked within the Genocide Convention itself. The issue of separating categories of Genocide, that is, of naming certain 'core', 'second circle', 'periphery', 'forgotten cases' also cuts straight to the matter at hand in this work: they might be just as inevitable in the sense that a Concept, for as long as it maintains certain layered temporal conditions that not only avoids grounding, but also refuses extreme cases of historicism, can only be made sense through the drawing of borders between what it must be, what it can be, what it should not be, what it could not possibly conceive itself to be. 
Thus, between the difficulties of extricating the Holocaust from "Genocide", at least as categorical concepts, between the possibilities and needs for comparative studies between 'typical genocide cases', we have claims for what "Genocide" is supposed to be. Claims that attempts to close off the possibilities of meanings of what, when, where a genocide might occur/have occurred/ will have occurred ${ }^{10}$, albeit attempts that must inevitably "fail" - in so far as one has some designs on a "scientific understanding' of the concept in terms much similar of the Soviet Delegation to the UN during the Genocide Convention, as we'll see later -, as the almost eternal debates of meanings of "Genocide" might have shown. This is where an exercise in understanding the political nature of the process of signification of the concept of Genocide, in its roots, might be useful within the Field of Genocide Studies - and in a lesser sense, within International Law.

\subsection{1. History and IR: Concepts and Time}

This research touches upon a series of puzzles and issues that can be found on the borders of interdisciplinarity between International Relations and History, alongside subjects such as International Law and, unsurprisingly, the field of Genocide Studies. In many ways, it is possible to argue that the field of International Relations has always had a somewhat troubled relationship with either History, historiography or the employment of concepts. As these two instances are partially related, my recourse to Conceptual History (Begriffsgeschichte) can be seen as an attempt to come to terms with such issues - if not 'limitations' - within IR.

By "troubled relationship with History and Historiography", I mean most of the issues raised by the so called Historiographical Turn within IR - if we follow Bell's (2001) terminology - or the "Historical Return", if we follow Hobden \& Hobson's (2002). By the issue of "employment of concepts" I mean, mostly, what Guzzini (2013, p.535-536) indicates when, considering certain meanings and significances towards what 'theorizing' entails, to the most common tendencies within social sciences in general in terms of conceptual instrumentalism and essentialism.

\footnotetext{
10 "Will have been", the future anterior, employed here as a grammatical tense that attempts to locate (and perhaps re-view) the past in the future (Shapiro, 2015, p.3)
} 
It is possible to argue that both issues are related in the sense that they require a serious appraisal of time and temporality in International Relations, both as a set of practises and as possibilities of analysis within our field - and, in a certain way, of determining or at least considering our own political imagination. Before discussing these issues with more detail and care, it is important to point out that my attempt to work with Conceptual History (Begriffsgeschichte) is, mostly, an attempt to come to terms with both problems. That is, to consciously weave around the problems and limits of certain modes of thinking historically IR- as discipline and as practises - and the articulation of concepts as the attribution of meaning towards certain categories of events, actions and decisions. Perhaps more than that, how certain concepts may be employed historically - politically - with a certain temporality that relates to a certain space of experience/horizon of expectations that has a lot to say in terms of our possibilities for understanding, employing, arguing for or against, certain conceptual enunciations.

Since the so called Historiographical Turn, through the 90's and 00's, there has been some serious attempts to grip the contentious relationship of disciplinary IR and disciplinary History. This debate can be linked to questions related to what IR, as a discipline, is supposed to study and, perhaps more importantly, how it does so. The "Historical Return" can be seen as a push towards a more, say, conscious employ of "History" (Hobden \& Hobson, 2002), either as narratives, as events or as certain aspects of disciplinary History itself, within IR.

This was/has been a concern that directly relates to the inherent problems of employing - and measuring - the validity of "Empirics" within the many schools that co-habit the IR field. If we follow the context of the so called fourth debate (Waever, 1996), it seems that IR has been dealing with questions that concern mostly towards the limits of commensurability and verifiability of truth-claims about the past and what the role of History within IR is taken to be. This tension indicated - in part but not exclusively - by the Historiographical Turn was, at first, a very common argument against what was perceived as the "ahistorical structuralism" of neorealism and other schools usually identified as 'mainstream', in favour of more contextualism, 
interpretativism and a focus on the event so that possibilities of change could be more seriously considered (Lawson, 2012, p.206).

It was certainly not, however, the first time that History was "taken seriously" in IR, albeit what is meant by that is certainly contentious. Usually, at this point, one can convincingly argue that structural ahistoricism was a small gap between bigger traditions of the historical traditions within IR, citing Carr as an historian himself, reflecting on the traditionalist approach of the early English School with not only historians such as Herbert Butterfield, but also with the long project of analysing what would be the "International Society" and "International System" - either as concepts in themselves or as basis for historical comparison between different contexts and frameworks - taken on, mostly but not exclusively, by Hedley Bull (Bull, 2002), Bull \& Watson (Bull \& Watson, 1984) and continued later by Watson (Watson, 1992), being also worth of note the point of what the "traditions" to International Thought, within Martin Wight's (Wight, 1960) work (R.B.J. Walker, 1989, p.167).

This is another way of stating what Hobson \& Lawson (2012) and Lawson (2012) have argued: it is insufficient, if one's to consider what "History" is in relation to IR, to charge structuralists of being ahistorical and then moving on. After all, it is not because said schools work with a specific kind of History that it does not have certain assumptions and claims on time and the past itself with support from certain schools and movements within disciplinary History.

As there isn't a single approach within IR, there surely isn't a single one within disciplinary History ${ }^{11}$. In other words: time and temporality is an ever present concern, directly or not, of forms of inquiry associated with International Relations, no matter if said, in a lack of a better term, "form of inquiry" looms towards more scientifically based claims to truth or to a more interpretativist - if not outright 'deconstructionist', if we consider Vaughan-Williams (2005) - approach.

This concern relates directly to the way concepts are usually dealt with in International Relations. As much as temporal questions are always, in a way or another,

\footnotetext{
${ }^{11}$ This point is further illustrated if we consider Elman \& Elman (2001), whose book represents an interesting way of establishing possibilities of dialogues between IR and disciplinary History, even if restricted to what they roughly label "methodologically traditionalist diplomatic and military historians" and "International Relations theorists who do qualitative case studies" (Elman \& Elman, 2001, p.1)
} 
inherent to processes of theorising, whenever we, as scholars within not only IR but also within Social Sciences in general, engage with the attempt to approach - or at least deal with - 'reality' through either our own or 'borrowed' frameworks and analysis, we end up, one way or another, dealing with Concepts, or at the very least with hermeneutic and linguistic issues.

On that note, there are certainly many ways of dealing with Concepts, and at least as many possible pitfalls. Guzzini (2013, p.535-536) presents at least two that are symptomatic within Social Sciences: the problem of instrumentalising and of essentializing the employment of concepts. The former is understood to "instrumentally define our terms as we feel best for coding, with no concern for their historical and wider purpose". The latter, also problematically, does the opposite:

It is not because we dig into the history of meanings and functions of a concept that we find their 'essence'. Concepts cannot be really thought independently of their semantic context and their pragmatic use. They are part of semantic relations. Their analysis is inevitably part of an interpretation within that semantic web (Guzzini, 2013, p.536)

We are presented here with two of the most typical pitfalls when theorising, or at least when employing concepts: while there must be a caution in terms of anachronism within our analysis, we must also be aware that, no matter how contextual we get, no matter how many sources nor the degree of confidence that we can place on them, there is always a gap between our own present and our interpretations and readings of the past. In short, looming within an analysis there is always (1) the danger of instrumentalising a concept, that is, of employing acritically a certain idea connected to our present into what we consider the past to have been in order, mostly, to win an argument and (2) the possibility of doing the exact opposite, that is, to suppose that we can have a direct and clear access to what a past concept (or even past reality) "really was", that is, of essentialising certain reading of the past and taking it to be necessarily - or perhaps 'scientifically' as it is usually claimed by a few - true.

\subsection{2.}

\section{Genocide and International Law}


We have, so far, tried to pose and map a few of the problems and issues that are related to the broad field of genocide studies and its relationship with IR. As much as there has been a somewhat inevitable conceptual dispute in terms of what Genocide is supposed to mean, most of the analysis uses as staging point the UN 1948 Convention. This might be a good starting point, at least as good as any other that attempts to interpret certain categories and forms of political violence that can be - loosely or not - related to what the idea of a Genocide is supposed to give meaning to, that is, what kind of narrative of certain forms of events the concept of "Genocide" is supposed to do. In this sense, if our goal here is to critically consider the implications of attributing certain shades of meaning surrounding "Genocide", and to mostly to show how said shades are always controversial, disputed and limited, then we might find the justification and need for a Conceptual History of 'Genocide'.

At the same time, if we are attempting to take seriously the relationship between language and events in order to understand the implications of a concept of Genocide, we cannot help but to direct at least part of our analysis towards International Law and its tumultuous relationship with International Relations. There is, after all, political consequences for the adoption of a certain conceptualization of "Genocide", that is, of what kind of event the concept attempts to give meaning to.

The argument here is relatively straightforward: as there is a certain temporality within certain events and their linguistic articulations - narratives, if one will -, it influences, if not outright affects, the establishment of certain juridical norms, such as the crime of Genocide, and how said norms are put into practice - or at least how that practice is cynically avoided. As Johns et al (2011,p.3) suggests, events have a disruptive potential from the normalization that International Law tries to impose, and re-impose, through efforts of contention and eruption.

These movements can be understood, linguistically, through the articulation of norms, treaties and conventions. In other words, the point here would be that there is a need to not only to understand the category of the event through its potentiality for interrupting, shocking, certain traditional forms of understanding a reality, but also to see language, through International Law in our case, as an attempt to normalise the effect of surprise. This is the key for us to understand at least a few of the 
shades of meaning of the Holocaust and possible consequences for (the possibility of) different articulations of the Concept of Genocide - through the Genocide Convention or not.

A good deal of the difficulties of identifying, if not conceptualizing Genocide despite the 1948 Convention, can be located within this relationship between International Law and, in a certain way, International Relations. There is a lot at stake between the Convention and the more than twenty-one concepts identified by Straus (2001): after all, to presuppose a more restricted or a wider concept (norm, convention, law) is to presuppose a certain relationship of normativity within International Law that not only cannot be taken as a given but also cannot be closed in itself. In other words, "widening" or "restricting" presupposes, in themselves, one kind of answer towards the legal dispute between concreteness and normativity within International Law (Koskenniemi, 2011, p.39).

This is what is partially meant when argued that there is a reference towards the limits to International Law - towards the category of the Event and towards its capability of solving International disputes per se. In the end, even if we attempt to interpret the relationship between events and language - as we'll try to do - through the analysis of documents, treaties, norms and their own process of negotiation, all that can be is an attempt to depoliticise the politics that are intrinsic to International Law, in part through a certain dichotomy between "Idealism x Realism", between apologia and utopia - if one will - on thinking International Law itself (Koskenniemi, 2011, p.43).

This impossibility of closing off certain shades of meanings in detriment of others is what opens up the possibility of an analysis of the Event as a category with all its possibilities for irruption and linguistic contention. If we are unable to make up a truthful claim towards International Law as a transcendental - or simply "technical" "apolitical" - reading or as a mere reflex on the pragmatic interests of States, it becomes in a sense inevitable that we attempt to avoid the issue by pressing our analysis towards case studies, towards different events that can be potentially read as Genocide. This is partially what explains the general tendency of the field of Geno- 
cide Studies towards comparative case studies ${ }^{12}$. The point here is to keep in mind both the uniqueness and the potentiality for generalization of certain readings of Events as a category. Each event represents a tension between the possibility of resisting totalizing readings of history (Marchart, 2007, p.21) but must contain in themselves - or, better yet, in our own readings of them - a certain claim to universality; The possibility of - at least a certain type of - Social Sciences is dependent on that.

In more specific terms, we ought to consider that as much as there is room for arguments towards the resistance to change of meaning of "Genocide" in diplomatic practice (Schabas, 2008, p.47), it is still necessary to keep in mind the contentious relationship between the Genocide Convention and the possible readings of the Holocaust as an event, between language and events, between, finally, certain notions of Time and of Space, of representation and action. This, in part, is what justifies the deployment of Conceptual History as a method and as an epistemological claim.

\section{3. On Conceptual History}

There is a need, now, for us to consider briefly what is meant by the employment of 'Conceptual History' as a framework upon which to consider the contentious relationship between claims for the Concept of Genocide and its relationship with the events it is supposed to make reference to. This next section will focus on discussing on a few of the objectives of Begriffsgeschichte and, perhaps more importantly, how to proceed, methodologically, on such a proposal.

Conceptual History is claimed to have a relatively close relationship with Social History. One possible reasoning behind such a claim would be the conditions upon which they both work with texts: the latter as a way to deduce extra textual circumstances and movements, the former limiting itself to texts and words (Koselleck, 2004, p.75).

This gap, however, does not necessarily hold up - especially if we engage with both approaches within their own historiographical methods. Without common concepts Society would be unthinkable while the same could be said about concepts which are based upon extremely complex socio-political systems, something that

${ }^{12}$ Cf. Jones (2011) 
could go beyond the mere relationship between 'concepts' and their linguistic communities. There is, after all, an uneasy tension between 'Society' and 'Concepts' (Koselleck, 2004, p.76).

This could make more sense if we keep in mind what Koselleck would call elements that are extra-linguistic and pre-linguistic. The latter being a direct influence from the phenomenological existentialism within Heidegger and Gadamer, while "extra-linguistic" is meant, roughly, as the physical, "real" world (Ifversen, 2011, p.77). Even if Koselleck has not worked thoroughly what he means by "reality", there is, between what the historian means with the relationship between "language" and "the world" a clear interest in being clear on the importance of the space of experience/horizon of expectations upon which concepts are brought to bear, as well as the complex process on how the usage of such concepts may end up changing "reality" itself (Ifversen, 2011, p.77-78).

It follows, form this, Koselleck's claim that social and political conflicts must be read and decoded within their own conceptual boundaries and self-understanding of past speakers and writers who were, then applying, invoking, disputing their possible meanings (Koselleck, 2004, p.80-81). "Conceptual boundaries" should be understood as related to the idea of a "space of experience" and "horizon of expectation", that is, as that which orients and limits the possibilities and forms of communication(Ifversen, 2011, p.79).

One still need to be aware, however, that there are certain limits to this kind of analysis: the process of reading historical sources - specially, one might argue, nontextual sources - cannot be done in the same time-present under which such sources were produced. In other words, each and every reading of certain past conceptualizations by future generations will alter the possible spectrum of possible transmitted meanings (Koselleck, 1996, p.62). In other words, conceptual histories do not, ever, end: not only because the future cannot be entirely fixed or determined ${ }^{13}$, but also

\footnotetext{
${ }^{13}$ While prognosis is possible, they will never be entirely related nor foresee "what's to come". Not only because of the limits between language and the events they are supposed to narrate, to describe, but also because of the inherent potential surprise that certain events may carry within them, overcoming existing spaces of experience
} 
because the past, while accessed through narratives, can also never be entirely fixed or closed (Farr, 1989, p.39-40).

This is also the circumstances under which Koselleck (1994, p.8) argues that concepts themselves do not "have a history", but their readings certainly do: they are altered based upon the experiences and expectations of future interpreters (Koselleck, 1994, p.10). This is not to say, however, that there is no linguistic continuity in the usage of concepts. Quite the opposite: even with - slight or large - changes of meaning on the usage of concepts in relation to their prior use, there is a presumption of some form of relationship with the former use of a certain Concept ${ }^{14}$. The point, here, would be for us to have in mind that the diachronic deployment of concepts, of its change or continuity in terms of its possible meanings, must be based upon the careful exegesis of texts and analysis of discourses within certain political disputes: the conscious or not - usage of concepts must be identifiable within the available vocabulary at the time ${ }^{15}$ (Koselleck, 1996, p.63).

Similarly, this argument implies that concepts have many temporal layers: that is, their meanings and interpretations have different temporalities. The idea, then, relates to the identification and temporalisation, within their social and linguistic contexts, different concepts - potentially represented with the same word. Melvin Richter (1994, p.124-125), for instance, summarises thus the four identified dimensions of modern concepts within the Geschichtliche Grundbegriffe: "Temporalization" (Verzeitlichung), "Democratization" (Demokratisierung), "Ideologization” (Ideologiesierbarkeit), and "Politicization" (Politisierung).

For our purposes it is worth to highlight the first and the last: "Temporalization" would indicate the possibility of acquiring new experiences through a certain temporal dimension within the categories of meaning of a certain concept (Koselleck

\footnotetext{
${ }^{14}$ This can be made clearer if we consider the different uses and meanings of "Koinonia Politiké" in Aristotle, "Societas Civilis" in Cicero, "Civil Society in the early modern British Society or "Societé Civile" in Revolutionary France, as shown by Koselleck (1994, p.10)

${ }^{15}$ If we consider our present goal of understanding, perhaps building, a conceptual history of "Genocide", this argument relates closely to the semantical field that revolves around the idea of 'Genocide', either before the concept was coined - that is, in the 20's and 30's - or or afterwards, in the later half ot the 1940's. In other words, we might be asking: how one would describe "Genocide" in 1944? 1946? 1948 ? What sorts of metaphors, of parallels, of discursive elements one would have to suggest so as to make sense of the specific event(s) that one would have in mind?
} 
\& Richter, 2011, p.9). In other words, "Genocide", as a concept, might be an indication of a series of events and experiences that are either in the past or that are 'yet to come': even if a neologism was coined only in 1944, it does make reference towards a series of events before the Holocaust itself, while Lemkin's efforts to push for International acceptance and the creation of an apparatus with the goal of prevention and punishment of future instances of Genocide should be read as a conceptual push towards what the future is supposed to be.

"Politicisation" may be a reference towards the deployment of concepts as weapons within a socio-political dispute, that is, as a conflict between politicallyminded agents towards the attribution of meaning within a certain concept. In the context of Genocide there is hardly a better example than the ("Supposedly", as a certain government would say) Armenian Genocide during and after World War I. The deployment of the concept of Genocide, thus, represents a political thrust that cannot be ignored by the agents who make use of it. To put it bluntly, "Genocide" can be considered, within the International, a sort of trigger: once one accepted and determined that a Genocide is in progress - or was in progress - there is the understanding that there can be no alternative but intervention aimed to stop the atrocities - or the attempt to punish those understood to be the perpetrators. This is partially why, for instance, the political dispute to what 'Genocide', as a concept, might mean is necessarily prior and under a 'case by case' basis. The moment of resisting the (un)willingness to intervene must be, then, before there is (some sort of) consensus towards possible readings of certain kinds of Events that can be read through the lenses of Genocide ${ }^{16}$.

It is possible to argue that the history(ies) of a concept is(are) formed through the traces that it either leaves behind or projects towards the future through the implicit novelty inherent to a new attribution of meaning within a certain concept (Koselleck, 1994, p.10). In this sense, even if a word remains the same, its contents, its meanings and interpretations may change substantially (Koselleck, 1992, p.138). The Contemporaneity of the noncontemporaneous of a concept relates, partially, to this temporal relationship between the singular and the recurrence inherent to this

\footnotetext{
${ }^{16}$ Consider, here, for instance, Kelly (2008)
} 
notion of traces between a context and another. This is a relationship that may be indicated either through language or through non-textual means. In other words, the premise of the function - or, at least, one of the functions - of Conceptual History would be to allow for the possibility of working with what is new and what is recurrent within History.

Thus, one can argue that the contemporaneity of the noncontemporaneous, alongside in a broader sense Conceptual History itself, could be seen as an attempt to give answer to a deep historiographical issue that has usually been plaguing most historians at least since a good part of the 19th century. This relationship between novelty relates to a specific critique of German historicism, especially on Meinecke (Olsen, 2012, p.29), on the 'stuff of history', or, at least, on the possibilities of differentiating natural sciences from the humanities in general and how such claims deals with a question of Time, of possibilities of repetition and change (Iggers, 1983, p.45). We are dealing, here, with the many ways that a scholar deals with time. Traditionally, within Western thought, "Time" can be seen through two extremes: within a linear, progressive, framework which establishes a direct and chronological relationship between past-present-future, and a circular framework, as indefinitely repeatable possibilities of action and consequences - of phenomena even, in a sense - within a limited universe. In a general manner, the latter is usually associated to the Greeks and romans, while the former is usually thought within a certain modern notion of progress (Koselleck, 2014, p.19).

It could be argued that this demarcation between linearity and circularity is already a narrative inherent to the modern notion of progress from the 18th century onwards. In a sense this is representative of an appropriation of historical time as an object of study - and action - of the modern historical agent (Koselleck, 2014, p.300). Novelty, in this context, is direct referent to "Modern Time" ("Neuzeit") that brings forth a certain movement, a certain stance towards an open future that presupposes, in itself, not only some sort of planning but also of protagonism and action within the historical agent. It is also in this context that a "History" closer to the modern concept of "History" is brought forth: the possibility of a "historical view" is inherently linked towards the possibility (if not 'necessity') of progress. There is, within this notion, a 
clear demarcation between past and future without which historical singularity would be simply impossible (Koselleck, 2014, p.301).

However, this is not enough. "Neuzeit" and "progress" may restrict - if not outright hide - certain structural conditions, certain layers of repetition and recurrence that are intrinsically linked towards the possibility of theorizing within the modern discipline of History. If one of Koselleck's goals is to draw a few points of contact between Social History and Conceptual History, it is essential to keep in mind that one of the main characteristics - in a sense - of both would be an analysis within multiple planes of historicity (Koselleck, 2014, p.303-304).

In other words, if Begriffsgeschichte is a method and a Theory of History that seeks to understand and reveal the contemporaneity of the noncontemporaneous inherent in concepts and their relationship within a certain notion of 'historical reality' (Villas Bôas, 2014, p.102), then both traditional western notions of time are insufficient. After all, every historical sequence has within itself linear and recurrent elements (Koselleck, 2014, p.19-20). This relationship would be represented through the metaphor of Layers of Time ("Zeitschichten"), a relationship that must be linked towards the possibility of accessing certain traces of experience.

We are dealing, here, with a certain relationship between events and structures (Koselleck, 2014, p.304). "Events" as originating from historical narrative, presupposes in itself a certain chronology, a certain "before and after" whose relationship might entail what could be understood as "diachronic structures": that is, as a necessary sequence associated to the organisation and order of a certain event, constituting some form of unity (Koselleck, 2014, p.304-305). In essence, this "before and after" end up becoming, within this framework, a prerequisite of History, even if socially limited within a certain reading, certain interpretation (Koselleck, 2002, p.105).

Structurally, however, there exists conditions prior to the event that are different to this chronological "before", which has within it a notion of return or, better yet, a notion of recurrence. This is one of the most important assumptions within Koselleck's framework: that is, the possibility - or the attempt at least - to consider the relationship between the chronological diachrony of events and their structural pre-conditions which are representatives of the accumulated experience of those in- 
volved in the specific historical process (Koselleck, 2002, p.306). Between "Event" and "Structure" one can never be explained in its entirety through the other: there is always an aporetic tension between both. They are, in other words, related but cannot entirely merge in themselves. This is one of the main points if one's to understand the procedural character of modern history: to understand events through structures, and structures through events (Koselleck, 2004, p.110). To put it in another way: "There always occurs in history more or less than that is contained in the given conditions" (Koselleck, 2004, p.204). From this, two important considerations must follow.

The first is related to the very relationship between Social History and Conceptual History, which connection could be located within the possibility of identifying, linguistically, these movements and temporalities which would allow us, in terms of events and long-term structures, to build a historical analysis. "Novelty" and "Recurrence" are always present within language through the relationship between pragmatics and semantics: the first is understood mostly from the unique usage of language in a specific moment, the second is the condition of possibility of conferring meaning (and understanding) of what is said or written (Koselleck, 1992, p.141). And yet, Language and History, through the relationship between pragmatics and semantics, and through the event-structure dichotomy, are mutually related and dependent, but cannot be merged in its entirety (Koselleck, 1989, p.649-650). One can argue, based on this context, that a Conceptual History represents more than a philological work that keeps track of the (political) disputes for the brandings, naming, and categorizing of certain realities (Koselleck, 2004, p.80), but also an analysis that keeps in mind actions themselves which, in any circumstances, run over expectations and the limits of language: surprising and disturbing those who are trying to make sense of what the witnesses themselves might be living, seeing, hearing, doing or even feeling (Koselleck, 1989, p.652).

This is a key argument for a multitemporal, layered, analysis of what Genocide "is". While it is possible to argue that the concept of "Genocide", per se, does not have a longevity which typical "key concepts", or "basic concepts" have - after all ,Begriffsgeschichte typically deals with centuries, not years or decades -, to look for the synchronic disputes - the short term, if one will - of a concept requires, too, the 
framing of the diachronic either through considering what kind of space of experience have allowed for that discussions to be made in the first place, or through considerations as to what horizon of expectation might be projected within a certain articulation of the concept. Thus, even if we limit ourselves between 1944 and 1948, it seems inevitable that we need to consider the ripples beyond and the readings before, that is, not only the very layers upon which specific experiences might form the basis upon which "Genocide" might be possible but also what kind of sediments one is expecting to leave in the future ground.

The second consideration that emerges has its origins within the relationship between "Space of Experience" and "Horizon of Expectations" and, in a certain way, is a continuation of the first. It is possible for us to argue that this is where what we may call "traces of conceptual elements" or "remnants of experiences" enters into contact. The former refers to the Layers of Time (Zeitschichten), that is, to the accumulation (and extrapolation) of past experiences into different temporalities (Koselleck, 2014, p.19-20). The Latter refers to the possibility of understanding and interpreting concepts, that is, to the very possibility of establishing the history(ies) of a concept (Koselleck, 1994, p.10).

When Koselleck attempts to establish different temporalities that are contained within certain traces of experience that accumulate, the argument ends up making a certain anthropological thrust ${ }^{17}$. In this context, at least three temporal layers, which can be understood roughly as short, medium and long term ${ }^{18}$ can be stressed. The 'first' layer is directly related to the event as a source of singular experience. In this instance, certain action is experienced as something irreversible and in a sense shocking. It could be argued that it is something similar to a few of the assumptions

\footnotetext{
${ }^{17}$ Olsen (2012) seems to suggest that this movement is about finding a certain ground under which to stand as an answer and critique towards German late 19th century, early 20th century historicism. The point is further elaborated when shown how Koselleck brought certain normative categories - which he'll later call 'key concepts' - from Schmitt, Hobbes, Arendt and Heidegger in order to rework the idea of Being in the possibilities of human existence, or at least as the possibility for "history to happen" (Koselleck, 2014, p.93-102).

${ }^{18}$ The words used might not be these, but the description of each layer sprouts a meaning very similar to those. It is also interesting to note a certain reference, if not similarity, towards Braudel (1995) in the very choosing of these three layers that divide, tension, and forms conditions of possibility of structures and agency in history. Koselleck was well aware of that, especially considering that he makes a direct reference to Braudel as one of the first historians to suggest multiple - and in a sense simultaneous - temporality in historical analysis (Koselleck, 2014, p.303)
} 
that are usually seen within political history; it also forms the conditions of possibility for a certain notion of progress: or, better, the idea that there are and can be events that are so singular that they help release forces that helps to unleash (social) forces that were otherwise repressed somehow (Koselleck, 2014, p.21).

The 'second' temporal layer represents a few conditions of structural recurrence within events. Koselleck argues that this second layer is, roughly, something similar to a medium-term and, thus allows for some form of recurrence and some sort of singularity. A good illustration of what is meant by that can be seen through certain social institutions like marriage. Each is unique in itself - specially for the couple to be married - but even this unique event is based on larger organisational rituals and practises that are institutionalised within a certain society (Koselleck, 2014, p.13).

Linguistically this could be represented through the relationship between semantics and pragmatics (Koselleck, 1992,p. 141). That is, "even he who wishes to say something new must express himself in an existing language" (Koselleck, 2014, p.22, my translation). In other words, even the creation of neologisms and the coinage of concepts must, essentially, have - direct or indirectly - links within an established language (Koselleck, 2014, p.22).

There is more to that, however: one must consider that even the singularity of an event is not contained, solely through its occurrence, but also through its possibility of achieving a certain degree of surprise. There is potential, here, for a rupture in the continuum between experience and expectation which could generate new experiences through the development of such novel circumstances. These must be captured - contained - even if it inevitably will not contain the whole of "what has happened" linguistically, post-facto. It is through this process that we may understand the possibility of the 'creation' and adoption of new concepts, as well as the stabilising and normalising function of language - and international law, perhaps, towards events "which are beyond the pale of language, and to which all words, all sentences, all speech can only react" (Koselleck, 1989, p.652).

The third temporal layer, roughly the 'long term', has biological, anthropological and social characteristics. By "biological" - or perhaps "anthropological" Koselleck is referring to what he calls meta-historical conditions that turns History 
itself possible: they are transcendental individual and generational experiences (Koselleck, 2014, p.24). The span of time between birth and death, the difference between inner and outer, above and below, of generativity - that is, between adults and children - as organisational principles within human communities: these, the argument goes, are all conditions which humanity shares with other animals and, thus, conditions every sort of effects, behaviours and, essentially, histories. Natural, perhaps, but socially conditioned and differentiated between peoples and societies (Koselleck, 1989, p.650-651; 2014, p.95-101). If recurrence in the medium-term is what conditions the singularity of events, no history, so goes the argument, would be possible without long-term structures; thus, meta-historical conditions (Koselleck, 2014, p.25). This can also be seen as his point of contact with his former professor in Heidelberg, Gadamer, even if ultimately the multiplicity - and simultaneity - of layers promotes a point of departure from a fusion of horizons of experience - 'prejudice', perhaps - to the layered temporalities that overlaps one another through experience and expectation (Koselleck, 2014, p.107-109).

What we have done so far can be seen as an attempt to delineate a few links between the metaphor of Layers of Time (Zeitschichten) and "Space of Experience". That, however, is not enough: "Experience", as an historical category, is inseparable from "Expectations". This duality would be representative of long-term structures without which no history would be possible (Koselleck, 2004, p.257). These, as historical categories, are crucial if we are to understand certain historical processes either through the occasion of certain 'events' or their multiple and contested readings. These are categories, then, that incorporates in themselves certain notions of past and future (Koselleck, 2004, p.258).

Both categories, then, must be seen together, even if they might possess a distinct general direction. "Experience" presupposes a present past: that is, events that are already past and are, in a certain way, incorporated, remembered and influent within present decisions and behaviour. "Expectations", on the other hand, is "the future made present; it directs itself to the not-yet, to the nonexperienced, to that which is to be revealed" (Koselleck, 2004, p.260). The former, then, can be seen as a spatial articulation that could be a unifying factor within several temporal layers, 
while the latter is intimately linked with a notion of the "horizon" which could be understood as a line behind which a new space of experience will unfold, but one that cannot, safely, be bet upon. In other words, "expectation" is usually defined based upon a certain accumulation of "experiences": they may be fulfilled, or they may not, for there is always this indeterminacy based upon the possibility of surprising events that will require, in a sense, to be 'stabilized', be it through language or otherwise (Koselleck, 2004, p.260-262).

This is not to say, however, that between experience and expectation there is an exact, correct, chronology in the more usual sense. Experiences are not fixed or eternal: since they are closely linked to memory, they can be transformed by fulfilled - or unfulfilled - expectations, by events and their sometimes surprising element(s) that may disturb, transform, or even reinforce the memory(ies) of certain past events. Even if they represent "that which has already happened", they can be altered, for experiences are intrinsically linked to an idea of narratives. To illustrate this point we might work, as Koselleck does, with a metaphor used by Christian Meier who describes experiences as "a glass front of a washing machine, behind which various bits of the wash appear now and then, but are all contained within the drum" (Koselleck, 2004, p.260).

What we have done so far should be seen as an attempt to understand Conceptual History as a set of claims that presupposes in itself much more than 'a method': it ought to be seen as a Theory of History that seeks to understand novelty and recurrence, repetition and change, structure and agency through historical times: through the tension between experience and expectation that represents the limits and possibilities for understanding through time, for invoking claims of knowledge in a way that articulates notions of futures and pasts (Koselleck, 2004, p.262-263). This might be the whole point of doing $a$ conceptual history of "Genocide": to allow for the muddying of waters of what it means to suggest that some sort of events could be associated with a certain idea of Genocide. If, as we will see later, each claim to what Genocide "is" reflects specific conditions to how one can read, perhaps predict an event - or an event that could have been. It is a claim that is contained, necessarily, within a specific space of experience/horizon of expectations but that, ultimately, as a 
scientific claim of sorts portraits itself in a somewhat timeless manner: Genocide is. Genocide is not. To appreciate the possibility for $a$ - and not 'the' - conceptual history - of Genocide or not - is also keeping in mind Koselleck's main claim of the aporia between language and reality through time, on how the former represents more or less what the latter is supposed to be, that is, while each history ['reality'] might represent more - or less- than the representation it might assume through History ['language']. More than an overarching claim for a correct, timeless form of knowledge, the following chapters ought to be seen as a few possibilities for framing, for understanding, the conditions of possibility for Genocide as historical claims for specific events -yet-to-happen - and to be prevented - and for events-to-be-read. 


\section{3. Genocide before Genocide: Raphael Lemkin, Barbarism and International Law}

\section{1.}

Introduction

The previous chapter was dedicated, mostly, to consider a few of the limits and stakes, a few of the problems perhaps, that the Field of Genocide Studies have been facing for the past decades - especially in conceptual terms. The relationship between certain enunciations of what Genocide might be, and the events that one is supposed to give sense to, to explain, to, finally, give meaning with the employment of that concept is not only a tremendously contentious issue, but an issue that, I would argue, can be appreciated through Conceptual History - either as a method or, more importantly, as a Theory of Historical Times. Thus the second movement of the previous chapter.

No less important was a consideration of how a 'space of experience', as a historical category, is also dependent, inevitably, on the language and its contentious, aporetic, relationship with reality, whatever that may be. It is in this light that we'll briefly take point on, in the next few pages, what it might mean to consider a "space of experience" with the idea of "Genocide". It relates, thus, to considerations on the semantic field that might surround the concept of Genocide and, also, the space of experience/horizon of expectations that permeates the field.

The concept of "Genocide" was first enunciated in Lemkin's Axis Rule in Occupied Europe (Lemkin, 2008). As many have indicated (Chalk \& Jonassohn, 1990; Hinton, 2012; King Jr. et al, 2008; Kuper, 1981; Lippman, 2002; Schabas, 2009; Shaw, 2015), the concept, as intended, does not make only reference to what had, then, recently happened in Europe but claimed a broader - and perhaps somewhat narrower - category of certain types of events that ought to be identified as "Genocide". Or, to put it simply, “The word is new, the crime ancient" (Kuper, 1981, p.11). This emphasises not only the conflictive nature of the concept, but also highlights the necessity for establishing said 'semantic field' in the sense that it allows us to consider seriously what would be at stake within its annunciation as such. 
The importance of a semantic field, to put in such a way, can be indicated in a more mundane manner if we take into consideration a report from the New York Times dated from October 20th 1946. It reads:

Genocide is a word coined by Prof. Raphael Lemkin of Duke University, adviser on foreign affairs to the War Department, to designate the criminal purpose of the Hitler regime. 'Mass murder' is inadequate, because no motive is implied. 'Denationalization' is no better because it does not cover racial extermination and because it means to most of us loss of citizenship or country. (KAEMPFFERT, 1945)

Thus, we have, alongside "Genocide", concepts such as "Mass murder" and "Denationalization". If we move a bit further back, we can also see the notions of "Barbarism" and "Vandalism" as stated by Lemkin himself in $1933^{19}$. It is possible to dwell in deeper if we consider, too, the humanitarian regime pre-world war II, i.e. the debate concerning crimes against humanity and crimes of war $^{20}$. Particularly this last point was not only heavily debated in terms of Nuremberg, but served as a justification for the continuance of discussions on what 'Genocide' ought to mean within the $\mathrm{UN}$ a few months later. We will address each of these issues separately in high hopes for a narrative of the semantic field that encircles the idea of 'Genocide'.

This chapter, then, can be seen as an attempt to make good on the notion that, despite a focus on the 1944-1948 time-frame, the concept of genocide was not a Fiat. We'll direct ourselves for a brief narrative that establishes a certain relationship between International Law and Genocide keeping in sight the weaving that ultimately led to a certain idea of not only what "International Law" in its humanitarian variant is supposed to be about but also the Zeitgeist - the spirit of the time - that allowed for a concept of "Genocide" to emerge when and the way it did. This is certainly not the first time this narrative is told, a narrative that typically has two intensely connected starting points: one can either begin with humanitarian law and the Hague Conventions at the dawn of the Twentieth Century while gradually paving the way until the 1948 Convention (Schabas, 2009), or one might as well focus strongly on Raphael

\footnotetext{
${ }^{19}$ Cf Lemkin, 1947; Power, 2002; Schabas, 2009; Shaw, 2015
}

${ }^{20}$ Cf Schabas, 2009 
Lemkin's life and career, from his origins in countryside Poland at the turn of the century to his academic career as an international jurist built upon the struggle against the oppression of minorities, to his narrow escape from Nazi Germany at the beginning of World War II to, finally, his work not only as an organiser of the Genocide Convention but as its flagbearer on its aftermath (Cooper, 2008; Power, 2002). This is a tale that certainly does not need to be bifurcated. In the very least, if we are to take seriously the relationship between the social and the philological, between social history and conceptual history, between phenomena and language, then this is a tale that we need to explore.

In many ways, it seems that the career in International Law by Lemkin was a product, if not an outright consequence if we are to consider what it did or did not achieve, of the Zeitgeist of the interwar period. From the strong impression of the word "prohibition" in his early infancy in a rural area in Eastern Poland in the preWorld War One Europe to his struggle against minority persecution in the 1920's and 30's follows a sort of pattern of action that was so pervasive, so common, and yet somewhat inefficient, of the ways of the League of Nations. If we are to consider this milieu in terms of International Relations, for instance, Lemkin faced relatively similar dilemmas that "idealists" and "realists" - as the story usually goes - supposedly have faced in the similar period. Consider, for instance, Lemkin's position in terms of the crimes of barbarism and vandalism: while it asks for a prohibition, it also can't do much but hope that, as a rule, it is truly adopted. Interestingly enough, one has a fair point when considering that if such law passed one would have a precedence to trial nazi crimes in Nuremberg in ways broader then as 'crimes related to the leading and the conduct of war between 1933-1945 in Nazi Germany and the occupied territories" (Lemkin, 1947).

Yet, if we are once again considering a few of the different spaces of experiences/horizon of expectations, one can only wonder how much of a stretch this argument might be, i.e. how far would the victors be willing to go considering the kind of precedence they would be establishing for themselves? This might be one of the points that we ought to be looking within the transcripts of the Genocide Convention. It would, also, be well worth it to consider the way under which Lemkin pressured for 
the realisation of the convention itself: from a somewhat idealist International Jurist in the 1920's and 30's to a, even if still somewhat idealist to the typical realist mind, a more down-to-earth intellectual who attempts to weave through the system in order to bypass its limits and difficulties. Just as social history intertwine itself with conceptual history, the concept of Genocide intertwines itself with Lemkin. Through this we can start to pinpoint the need for a perhaps broader re-evaluation of a conceptual history of Genocide as linked to Lemkin's work.

Through these lenses that we can argue in favour of the path chosen by this following chapter. If we have to consider what "Genocide" might have been before "Genocide", that is, what sort of experience and expectation might have set the conditions of possibility for a certain linguistic novelty in the form of a 'new concept' even if, once again, 'the crime was not new', as Kuper (1981) once stated. The proposal here is to achieve such a claim by intertwining Lemkin's autobiography, ${ }^{21}$ that is, his own perceptions, understandings, in terms of his own struggle against Genocide, with some of the dilemmas that the book presents us are strongly related to the problems and difficulties that International Law was going through in the same period: a space of experience/horizon of expectations of what "Genocide" is, was, could be, cannot avoid such debates.

\section{2. \\ Early Beginnings}

He received no thrill from supernatural terrors, nor did he seek to delude himself, but it was not his nature to believe either in life or in death, in an absolute way; for him, life and death were the reverse and the obverse of the same phenomenon; past, present, and future were one for him, and all the proofs that our appearance as living creatures is inseparable from the presence of the departed were precious to him, and all the proofs that our appearance as living creatures is inseparable from the presence of the departed were precious to him (Raval, 1952 ,p.51)

\footnotetext{
${ }^{21}$ Raphael Lemkin died in August, 1959, with his autobiography still incomplete. It had reviewed drafts of most chapters, with only the last one actually missing. The written chapters and the outline of the last one were published in 2013 in good measure to the effort of Prof. Donna-Lee Frieze, who has formally edited and digitalized the manuscript, and has written the book's introduction.
} 
The opening passage was taken from Raval's description of Rainer Maria Rilke in a book that not only Lemkin had read, but had carefully done so. This passage, in particular, within Lemkin's copy was heavily marked in red ink (Lemkin \& Frieze, 2013). While stating a lot in terms of Rilke's, one of the major german-speaking poets of the early 20th century, - and in a certain way Europe's -, romanticism, spirituality and cosmology at the time, it is also a relatively good indicator on Lemkin's 'metaphysical life' (Cooper, 2008, p.270-271 ; Lemkin \& Frieze, 2013). There is a melancholy in this passage that reveals not only Rilke's capacity to relate to the sublime within European life, but also the ways it might relate to Lemkin's own views on life and its presencings/absences, its own limited temporality in the encounter between the living and the departed: between those who are - brutally - gone and those who remained, that somehow survived the holocaust. The point here would be to suggest that there is more, so much more, to Lemkin and the struggle for a Convention on Genocide than a sociological definition of what "Genocide" ought to be, even if ultimately this is a position that cannot be, should not be, excluded.

Lemkin had a relatively happy childhood in a rural tenancy in the region of Ruthenia, close to the city of Wolkowysk, formerly belonging to the Russian Empire, then to the Second Polish Republic and finally, nowdays, to Belarus. Historically, thus, the region was a zone of dispute between ethnic Poles and Russians, with a large Jewish population in the middle. In the words of Lemkin:

When three persons [sic] are in one bed under a common blanket, and when the man to the right pulls the blanket to himself, while the man to the left does likewise, the man in the middle is sure of being covered by the blanked (Lemkin \& Frieze, 2013, p.3).

The nature of this relationship is important for two main reasons. The first being the obvious and almost everlasting presence of antisemitism in Europe in general at the time. The second, however, might be a bit more interesting. The tensions between Jews and Russians, for instance, can be felt and seen in the very possibility for existence, or "the right to live", as Lemkin once put it, for himself and his family (Lemkin \& Frieze, 2013, p.12). 
Being part of the Pale of Settlement of the Russian Empire, Ruthenia was one of the many regions under which it was, by royal decree, prohibited for Jews to own agricultural land. Such a decree, however, was mostly circumvented by constant bribes to local police which in essence made Lemkin state that his "personal life and the life of the two families around this farm was illegal." (Lemkin \& Frieze, 2013, p.12). Through both the analogy of the blanket and this relationship with the authorities we might start to glimpse upon a sort of distrust, to say the least, with the figure of the State by members of a minority. When describing the police officer who constantly received the necessary bribes, it was stated that

There was something ominous and oppressive in his waiting, for we learned later why he was coming and we were aware that most of the time our parents had no money. (...) We learned very early in our childhood to dislike this man and to fear him as a symbol of our bondage (Lemkin \& Frieze, 2013, p.13).

While one has to admit that the first few chapters, at least the chapters that covers his infancy until his escape from war-torn Poland, seems to be a little more than a strong narrative, even if a narrative that seems carefully crafted with the power of hindsight in the 50's, we can still see, from this perspective, the kind of thinking that in the very least conducted the 'father of the Genocide Convention', i.e. even if the autobiography might not be much more than a crafted narrative to highlight a sense of destiny in the struggle against Genocide, it still says a lot about the sociological thinking, the train of thought even, of Lemkin when considering the process of defining and criminalising Genocide. The narrative, here, highlights a few important episodes.

The first would be the Bialystok pogrom ${ }^{22}$, occurred in June 1906 when Lemkin was six. It roughly coincided with the authors' read of Quo Vadis? ${ }^{23}$, which lead to the thought that "A line, red from blood, led from the Roman through the gallows of France to the pogrom of Bialystok" (Lemkin \& Frieze, 2013, p.17), and the begin-

\footnotetext{
${ }^{22}$ Occurred in June of 1906, the pogrom caused the death of more than 80 Jews who lived in the city of Bialystok. In the words of Lemkin "the mobs had opened the stomachs of their victims and stuffed them with the feathers from the pillows and feather comforters" (Lemkin \& Frieze, 2013, p.17)

${ }^{23}$ A historical romance written in the late 19th century by polish author Henryk Sienkiewicz. It depicts the persecution suffered by the early Catholics in the hands of Nero
} 
ning of his biblical studies. Even if we might need to take the temporality of the narrative with a pinch of salt, being more likely that the line red from blood ought to be read as starting in Bialystok and 'going back' until the Roman Arenas, that is, that the Bialystok pogrom itself might have ignited the theme of ethnic mass murder in the young Lemkin (Cooper, 2008, p.10).

From the deep impression left by Bialystok the reader is presented with the Beilis Trial in 1913: a Jew, Menahem Mendel Beilis, was accused of ritually murdering a Christian child in Kiev. The case had strong repercussions in the Empire, reinforcing an ominous atmosphere of the general population against the Jews. In short, a child was murdered, in 1911, with several stabs to the stomach. Even with the investigation indicating as suspects a local gang, an anti-Semitic newspaper accused Mendel Beilis of ritual murder ${ }^{24}$. Despite many attempts to impinge false and flimsy proofs against Beilis, he was eventually found innocent by the jury (Cooper, 2008, p.10). Although the results helped to relieve the tensions in a situation where a guilty verdict might have led to massive pogroms, the closeness to which tragedy was avoided did not escape the Jewish population at the time for "The axes, hammers, and guns were already prepared while the jury deliberated" (Lemkin \& Frieze, 2013, p.19).

The novel, the massacre and the trial, thus, could be associated with the beginning of the author's thought on what would later be labelled as Genocide, i.e. the intentional murder in total or in part - to paraphrase the later Convention - of members of a specific group. As a member of a persecuted minority by the general population which enjoyed if not always outright support but a convenient leniency from the authorities to persecute ${ }^{25}$, we can start to glimpse on the experiences that might have led to the concern and struggle for the outlawing of Genocide. And yet, from there to International Law there were still ways to go.

\footnotetext{
${ }^{24}$ In the case it was argued that the murder was for a 'blood libel', which most people then associated with the myth that the celebration of Passover would require the blood of young children. It was a somewhat common anti-Semite accusation.

${ }^{25}$ One can point towards, here, the many pogroms that happened in the early formative years of the polish republic in both the tumultuous retreat of the German armies in 1918 and the wars between the soviets and the polish in the early 20's. Battles were used, in many instances, as opportunities for pogroms to happen (Cooper, 2008, p.13)
} 
While these episodes gave Lemkin a sort of sensibility towards the plight of minorities with the State - alongside a somewhat lack of trust in State authorities -, it was the trials of Tehlirian and, years later, of Samuel Schwartzbard that droved and confirmed his interest in Law, particularly International Penal Law. Lemkin was a student of philology in Lwów ${ }^{26}$ when Soghomon Tehlirian, a survivor of the Armenian genocide, murdered Talaat Pasha in Berlin, one of its main perpetrators. The trial court found itself in a paradox: while it could not morally condemn the act of Tehlirian, it could not also openly condone justice taken by one's own private hands. The defendant was found temporally insane and acquitted (Cooper, 2008, p.15).

The trial was significant towards the drive that led Lemkin to more concretely consider the problem of mass ethnic murder. He described Tehlirian as he "who upheld the moral order of mankind" and that he "had acted as the self-appointed legal officer for the conscience of mankind" (Lemkin \& Frieze, 2013, p.20). This line of thought not only made Lemkin change courses towards Law, but also led to an interesting argument against his professors. In his words:

They [the professors] invoked the argument about sovereignty of states. 'But sovereignty of states', I answered, 'implies conducting and independent foreign and internal policy, building of schools, construction of roads, in brief, all types of activity directed towards the welfare of people'. Sovereignty, I argued, 'cannot be conceived as the right to kill millions of innocent people (Lemkin \& Frieze, 2013, p.20)

This dilemma was revived about five years later, when Samuel Schwartzbard was under trial in Paris for the murder of Symon Petliura, an ex-minister of war of Ukraine who played a large part in brutal pogroms during the Russian civil war. Once again, in front of overwhelming evidence of the avenge of ethnic mass murder, the court acquitted Schwartzbard on the grounds of temporary insanity. It could be argued, in this sense, that both trials helped shape, helped to form, the very idea of the kind of crime that Lemkin sought to typify years later:

After the Schwarzbard trial, I wrote an article in which I called Schwarzbard's act a 'beautiful crime'. I deplored the absence of

\footnotetext{
${ }^{26}$ Currently called Lviv, in Ukraine
} 
any law for the unification of moral standards in relation to the destruction of national, racial and religious groups (Lemkin \& Frieze, 2013, p.21).

While these trails gave motion to his, say, desire for the struggle to formulate a law of sorts against the sort of crimes practised either by Talaat Pasha or Petliura within International Law, Lemkin was conscious enough to realise the need for a forum upon which to advance these interests, which is partially why the young academic set forth on writing a series of books in the following years which, alongside his contacts in the Law School, led him to the position of deputy public prosecutor of Warsaw, in 1929, - not a small feat for a Jew in Poland in the 1920's -, secretary of the penal section of the Polish Committee on Codification of Laws, representative at the International Bureau for Unification of Penal Law, and Secretary General of the Polish Group for the Association of Penal Law. Especially the last two were crucial for they allowed him International Contacts in the International Law milieu that greatly facilitated not only his survival against Nazi persecution ${ }^{27}$, but also helped attempts - that ultimately failed - to push for legislation against the crimes of Barbarism and Vandalism in 1933 at the International Conference for the unification of penal law, in Madrid (Lemkin \& Frieze, 2013, p.21).

While his participation in the conference was barred due to pressure from a polish anti-Semitic newspaper - Gazeta Warszawska - Lemkin was able to send forth his article in the defence for the creation of the crimes of Barbarism and Vandalism the former being defined as the crime of destroying a national or religious collectivity and the latter being defined as the destruction of the works of culture which represented the spirit of a certain national and/or religious collectivity -, a defence, in Lemkin's own words, based on a worldly, perhaps international even, conscience whose expression could also be found in the elimination of evils such as slavery, trade in women and children, drug trafficking and piracy (Lemkin \& Frieze, 2013, p.23). While he was not allowed to travel to the conference, he was able nevertheless, through his own contacts in the press of the League of Nations, to publish his papers and to guarantee that they would be tabled, i.e. that they would be read out loud in a

\footnotetext{
${ }^{27}$ His process of admittance to neutral Sweden and later to the US with an academic job lined up in Duke University came from two contacts Lemkin made back in the late 1920's, early 1930's.
} 
panel but could not be neither shot down nor approved per se (Cooper, 2008, p.21; Lemkin \& Frieze, 2013, p.23).

The narrative, here, can be bifurcated at least in two paths. While the wish to prevent and punish future cases of mass ethnic murder, based on his own experiences as a Jew living in the Russian Empire and subsequently Poland, and as someone who accompanied the development and the conclusions of the tragedy that befell the Armenians during and after World War I helps us to understand what drove Lemkin to the path of International Law as a solution to what would later be called 'Genocide', he was by no means the sole jurist dedicated to the matter, especially if we consider, for instance, that the concept of 'Barbarism' as attempted to be defined by Lemkin was credited, originally, to Romanian jurist Vespasien Pella (Cooper, 2008, p.19; Schabas, 2009, p.26).

The second path is related to the terminology employed here: to embed both concepts of Barbarism and Vandalism to a "international conscience" is a kind of grammar immersed in a very common patter of the struggles of modern International Law since its beginnings in the late 19th century (Koskenniemi, 2002). These struggles, we would like to partially content, not only makes reference to certain promises towards what the League of Nations, what "International Law" pretended itself to achieve in the, not exclusively but most intensely, post-Great War world. A struggle and set of promises and intentions that is usually deeply immersed within the almost mythological origins of International Relations as a discipline. If we have the intention to make sense of what was at stake within the dispute of what "Genocide" might have meant in 1944-1948, this is a debate that we cannot forsworn to engage. This is the point of our next section.

\section{3.}

\section{International Law in the Interwar Period}

This section will direct itself to discuss, briefly, the conundrums that pervaded International Law in the Interwar Period. This is unavoidable if we are to consider what might be a possible 'semantic field' of Genocide both in its linguistic and in its phenomenological sense. It will also help us to understand not only, say, 'what was lacking' for the concept of Genocide to emerge, but also what was at stake for its 
'predecessors', Barbarism and Vandalism, not only not to be taken seriously but how they both reflected a certain mood that was so prevalent in the Interwar period in terms of what International Law was supposed to 'be able to do' on its own. It is, in essence, the age-old debate of power against law of the early years of International Relations as a discipline.

In many ways, it seems, the argument of Lemkin against his own professors after the Tehlirian trail captured the mood of the roles of International Law at the time, especially in terms of what Sovereignty was supposed to mean and in terms of the role of International Law in the face of State power politics. While Koskenniemi (2002, p.13-15) suggests that modern International Law was a product of Victorian mid-late 19th century Europe that simultaneously had to deal with the emerging "National Spirit" that was waking up all over Europe and the "esprit d'Internationalite" that defended "nations and races to follow certain common principles not only in their mutual relations but also in their domestic legislation" (Koskenniemi, 2002, p.13).

For our purposes, it is also important to highlight the differences in interpretation of the Law in those early International Jurists and, for instance, Lemkin's take on the purpose of International Law against minorities. For Gustave Rolin-Jaequemyns ${ }^{28}$ (1835-1902), for one, this purpose can be seen as both the, then, 'increasing influence of humanitarian ideas in the limitation of warfare and in the conduct of hostilities' (Rolin-Jaequemyns apud Koskenniemi, 2002, p.15) as set in the 1864 Geneva Convention, but, most importantly, that:

although it had become common to treat unilateral acts by and treaties between States as the sources of international law, their force was not due to their form - after all, 'on les viole aussie souvent qu'on les invoque'29. Their force arose from public opinion (Koskenniemi, 2002, p.15)

This, of course, does not mean the participation of the masses but a very specific 'educated public opinion', one that is 'based on the application of certain principles of public justice' (Koskenniemi, 2002, p.15).

\footnotetext{
28 'An avocat from Ghent' and one of the founders of the "Revue de Droit International et de législation Comparée", the first international law journal at the end of 1868 (Koskenniemi, 2002, p.14)

29 "We violate them just as frequently as we invoke them", my translation
} 
This kind of reading of what a 'public opinion' ought to have been, in short, can be read as the very own reading of the figure of the International Jurist, in a sort of amalgamation between the conscience - of 'mankind' as in 'international mankind' - and science, i.e. an idealised sort of science that gave, in the very least, a degree of self-legitimacy towards 'the man of [legal] science' as, once again, in the figure of the International Jurist (Koskenniemi, 2002, p.16). In many ways this can be understood as the legitimising basis upon which much of the early 20th century, especially the interwar period, thought about the conduction of International Law and International Relations. Lemkin was no exception.

Such process, as we would argue here, can be seen as deeply drenched, strongly intertwined with the IR discipline, or at least a few of the myths that gave (a sort of) life to what International Relations - supposedly - was/is about. While I am making reference here to a certain reading of what came to be understood 'the first great debate' between a sort of idealist and a sort of realist, the point is not to reinforce such mythological readings - as De Carvalho et al (2011) once put it - but to consider what kind of milieu, what kind of, to be more precise, space of experience Lemkin was immersed and influenced by. Not to argue, however, that he was particularly aware of any kind of 'debate' in terms of 'International Relations', the discipline, but to suggest that whatever contacts he made in the 20's and 30's, whatever forums he sought after in his attempts to advance the crimes of Barbarism and Vandalism in 1933, they were all deeply entrenched in the context of the League of Nations and claims to what International Law was supposed to do in light of the goal for the advancement of Peace - and perhaps security towards minorities within the State.

While we certainly do not wish for a reification of sorts of the old myths in IR in terms of who were the utopians/idealists/Liberals and what they were supposedly doing/thinking/writing, as it seems to be the common practice within International Relations (de Carvalho et al., 2011), we ought to notice the point that most jurists, when adventuring forth towards 'the International', tends to do a little more than expanding most of the enlightenment corollary - 'the Rule of Law' - from Domestic Politics to International Politics - or perhaps Society, if one will (Koskenniemi, 2011, p.36). This, surely, is not a move that is exclusive to them, one needs only to be re- 
minded of the inherent difficulty in terms of dealing of what is proper of the International, whatever that may mean, and what would be proper of the domestic sphere: or, to put it succinctly, one might ask "Why is there no International Theory", as Martin Wight (1960) have done so many decades ago.

Perhaps a better way to frame (one of) the issue(s) within International Law, especially but certainly not exclusively, during the interwar period would be from the notion of International Laws' "flight from Politics" (Koskenniemi, 2011, p.36), i.e. the unwavering faith in the 'Force of the Law' brought forth since at least the enlightenment. Such faith can be traced at least since the abandonment of the principles of natural law in favour of liberal principles such as freedom, equality and rule of law (Koskenniemi, 2011, p.36). Thus we have to face simultaneously the inherent problems of demarcation in terms of what the International is (not) and what is possible to be done, analysed, considered, when attempting to deal with such a demarcation in terms of what the Law is supposed to do. This last instance can be seen as that which one may call a fight - of International Rule - against politics, i.e. the subsuming of certain practises - diplomatic practises, for instance - under a certain idea of (International) Law: as the possibility of seeing, building, following, a certain System whose behaviour ought to be understood as, explained as, analysed as, conditioned as certain bodies of public law (Koskenniemi, 2011, p.36-37).

If, on the one hand, we - as International Relations Scholars - have been facing with certain narratives that portrays our field not only as nascent from the bloody trenches of the Great War but also as a supposedly debate between Idealists, Utopians perhaps or Liberals in some cases, who wanted to avoid a next war no matter the $\operatorname{cost}^{30}$, and (certain forms of) realists who were attempting to see 'things how they really were' (Carr, 1940; de Carvalho et al., 2011), on the other hand there is a need to reconsider - as many who have turned to the historiography of the time have been doing for the past twenty, thirty years - what those said utopians, said idealists, said utopians have been working on, i.e. how they closely related themselves to those jurists who conducted the affairs of the League and, thus, had a lot to say in terms of what the (International) Law was supposed to do, at least if one were to attempt make

\footnotetext{
${ }^{30}$ In the sense that the will to achieve a goal might, at first, surpass a supposedly reading of what 'the reality really is' as suggested originally by Carr (1940).
} 
good on the promise of the 'war to end all wars'. This, in other terms, helps us to ponder on what would be the point of considering the complex relationship between not only 'Law' and 'Politics', but also the very 'Politics of the Law' and, thus, what one might hope to achieve - in the proper forum or not, as Lemkin attempted to do in 1933 and later in 1944-1948 - in terms of struggling for a Law, a Convention, that allows for the punishment and prevention of what later came to be understood as Genocide.

Thus, if De Carvalho et al (2011) seems to suggest that this typical reading of the 'Great Debates' is more about a certain whiggish reading of what history must have been - in order to legitimise certain practises in the then present -, they - those who put forth such reading - might not have been that much off the mark if we consider the also whiggish nature of those Liberals back in the end of the Great War, of those Liberals who were proposing, then, forms to avoid another war and to build the 'framework for a lasting peace', if we are allowed to follow Leonard Woolf's (1917) book name and structure. Surely those authors - Henry Noel Brailsford, Leonard Woolf, Woodrow Wilson himself, Albert Frederick Pollard, Alfred Zimmern, to name a few - probably did not fit the image of innocent deluded idealists as a few might have painted them in IR years later, but they certainly followed certain traditions of what the International Law must have been and what it must do, not in the sense of will trumps nature that Carr (1940) probably imputed them, but more likely closer to the sense that a framework of a lasting peace must transcend the debased world of politics, i.e. the Rule of Law must transcend the struggle against concreteness - distancing the Law from certain theories of the natural justice - and against what is taken to be typical behaviour of men and state, that is, enforcing its normativity (Koskenniemi, 2011, p.38).

To put it simply, the problem that these jurists, historians and the like were facing can be summarised under the principles that, first, the Law must be applied regardless of the preferences and behaviours of the legal actors - citizens, States, take your pick - but also cannot be considered beyond or above the social circumstances that created them, i.e. they are not a natural, but an artificial creation (Koskenniemi, 2011, p.39). This point is made relatively clear when we consider, for instance that: 
War will never be slain by reasons or political institutions and organs alone, by arbitration or arbitration courts, by conciliation or counsels of conciliation, by Holy Alliances or Leagues to Enforce Peace. But the crowds who throng the other side-track, who, because they see this, leap to the opposite conclusion that reason and political institutions can do nothing to prevent war, are equally wrong. It may be true that war will exist so long as the will to war exists, and that there can be no peace without the will to peace, but the absence or presence of international organization, such as councils and tribunals, is part cause of the existence of the will to war or the will to peace (Woolf, 1917, p.10 emphasis in the original)

Swap "War" for "Genocide" and we might be getting closer of the whole point of this discussion. More particularly in terms of what Woolf (1917) was arguing, the main idea would be that International Relations - any kind of Relations, for the matter - can only be regulated either by means of force or means agreement, which, roughly, presents us with the dichotomy of power and law. His argument is not necessarily that one will always prevail over the other, for it depends on 'the will' of the legal subjects, in a manner of speaking, but it affirms that a sort of impartial tribunal to solve differences is historically possible and should be the basis upon which the (then) future courts of the League of Nations should be all about: the process of (impartial) arbitration and the acceptance of its decisions based upon the "will to peace' of the nations which have - supposedly - freely formed the League: force is not ultimately excluded, but we have, here, the somewhat patronising, if not Imperialist/Racists - arguments that the civilised nations are the ones to be proved as such through the acceptance of such a tribunal, that is to have a will-for-peace (Woolf, 1917, p.19-21). The elaborate part of the argument, however, can be said to be the distinction between the civilised and uncivilised as another form of separating who is able to sit at the table and who is the enemy of democracy, the West, the International System, International Society, whatever name we may choose to pick. It is, in other words, clearly part of the movement "away from politics", from moves and attempts to depoliticise the rule of Law, however much political it inevitably, at the bottom, it still is. 
It is, also, a relatively covert way of suggesting that Albert Frederick Pollard was right when announcing that the Great War was actually a sort of Civil War - Bellum Intestinum -, not for a 'world state', certainly, but for which tide - democracy or aristocracy, civilisation or barbarians - ought to cover the world: as in a dialectical movement that serves to help the guiding principle of the destiny for unity of the International, the "growing pains of unity" (Pollard, 1918, p.7), ultimately suggesting not only that there is room for force in the world - to speed up the process of peace through an elevation of certain ideas in detriment of others - but also leaving implicitly clear that the (future) Rule of Law - the future League of Nations - is valid to those of the civilised nations.

This somewhat dialectic movement, with its dreadfully enlightened terms, was a relatively common discourse in terms of what the then future League ought to be. The intricacies of the issue for the future peace were interestingly exposed in 1919 by Brailsford when comparing the possibilities for 'one league or two leagues', using, here, the term 'league' loosely as the sort of pre-Great War alliances, i.e. a sort of almost blind commitment to the 'stemmed ally' that most likely helped push things into the warpath in 1914 (Brailsford, 1919, p.9). This set of claims partially helps to demolish the simplistic view of the then liberals that the - global - economy would have made war obsolete - a view long explored, and criticised, by Carr (1940) and many of the builders of the myth of the first great debate (de Carvalho et al., 2011) when it was probably quite the opposite in the sense that economic needs both fuelled and were fuelled by political needs, at least between blocs of alliances (Brailsford, 1919, p.11). Essentially:

if the aim of a League of Nations be to restrain lawless forces and to prevent the recurrence of such a conflict as rages to-day, it must furnish an international organization which can ensure that timely changes shall be effected in the world before any people is driven by an intolerable grievance or even by a reasonable ambition, to force change by arms. (Brailsford, 1919, p.15).

Or, to be succinct, the role of International Law ought, one might insist, to be above and beyond Politics, i.e. it must placate the conservatism need for the already powerful - like Britain - but also placate the 'have-nots', the many nations vying for a place 
under the sun, to summon a back then common terminology. And yet, even the author has to admit, however, that politics in a certain sense always strikes back: the (then) future League might commission a court for controversies, might turn war unlawful, might even go to war to defend its own members and tenets, but - and this is especially the case for our last statement - it cannot ultimately avoid, if a malcontent nation so chooses, to avoid a future war in the same mould and dreadfulness of the last one between 1914-1918 (Brailsford, 1919, p.16-17). Thus we have, here, an example of what was meant by the inherent difficulty of dealing with the concreteness and the normativity of International Law (Koskenniemi, 2011, p.38).

The grand issue here, however, would be the question of pitting what the League 'should have been' and what it 'apparently was', i.e. a contrast between the high goals of International law and the inherent difficulties raised by politics. Between claims for a common purpose, common alliance (Brailsford, 1919) or sheer unity of a democratic world (Pollard, 1918) and the baser needs and developments of International Politics that ultimately crashed down in September $1939^{31}$. In this sense one could argue that the League - and this perhaps can in a relatively safe way be broadened towards International Law itself - might have been built considering the possibility - or at least supposedly aiming - for arbitration, consent and peace with the emergence of a certain International Consciousness, what the world was presented was that:

the overwhelming majority of the states of the world have become members of the League of Nations. Yet, in spite of their regular meetings, they have not been able to work out a common policy. There is no such thing as a League of Nations policy (Zimmern, 1936, p.295 emphasis in the original).

This difference between "what should have been" and "what one supposes that it is" is what Koskenniemi (2005, p.16-17) would suggest as a problem that ranges from utopia to apology (to politics). Roughly, the argument would be that Modern Law cannot hold itself to a higher claim of morality from nature, god, whatever: it

\footnotetext{
${ }^{31}$ Which, of course, is not to say such developments were already well under way beforehand. Consider, for instance, Morgenthau's (1939) analysis of the failure of collective security against the (then) too late return to neutrality
} 
must be based on 'the real', on the historical, temporal, political, spatial conditions, but it must also somewhat be independent, in case of International Law, of interests of the States least it becomes little more than a form of apology to power (politics).

Thus, I would suggest, we can start to grasp on at least one of the issues faced by Lemkin not only in 1933, when he tried to advance the concepts of Barbarism and Vandalism as crimes under International Law, but also the challenges faced by him when trying to weave the Genocide Convention through the new-born United Nations, or, if we want to go there, the problem of seeing Genocide as mostly a sociological question, as Shaw (2015) seems to suggest. Perhaps, after this short detour, it is time we head back to our narrative of sorts by where we somewhat stopped, that is, by the struggle to pass the Vandalism/Barbarism concepts.

\section{4.}

\section{From "Barbarism" and "Vandalism" to the United States}

When recalling an encounter, back in Latvia in 1939 as a war refugee waiting for an approval to move to Sweden, Lemkin affirms having a conversation with Bronislaw Wroblewiski, a friend and a criminologist, with whom he supposedly declared that:

In all periods of transition moral standards break down. This does not mean that we should accept it passively - we must try to set the standards up again. We must even raise them more forcibly. We cannot disregard the changes; we must take them into consideration (Lemkin \& Frieze, 2013, p.64).

Whether this conversation happened at all, or even if it did but not in these words might be irrelevant for our purposes. All in all perhaps few sentences could reflect better what we have been trying to achieve in the previous section. Even a dreadfully cynic person who takes such claims to have been made back in 1939 with a pinch of salt ought not to help but admit that it has value even if as a reflection on the mood of International Law milieu even if in the late 40's/early 50's when this autobiography was being written.

In short, within this quote, we end up facing personally and directly what was meant by the almost perennial problem of concreteness and normativity within International Law. While to state that to be in a 'period of transition' might not be much 
more than a symptom of relatively common conditions of modernity as a process of accelerated change, transformation and promises of the new and better future through the enlightenment (Koselleck, 1988; 2004), it also means that, at least somewhere along the way, Lemkin was perhaps keenly aware of the fraught difficulties inherent to what International Law was supposed to accomplish, even if ultimately he held it on a high, hopeful, note. Just as the modern revolutionaire that had his hopes in a better world through revolution eventually met disappointment with the 'real world', or the medieval prophet who adjourned his predictions when prophecies continuously failed to materialise (Koselleck, 2004). The International Jurist, in the face of politics per se, in the face of an apology to power, could not help but appeal, and keep appealing, to utopia, to the normativity of the Law as something that must, because it has to, because the alternative would be perhaps far too dreadful, because the rule of the Law was supposed to be always better, be insisted upon, be raised again, even if ultimately forcibly.

The movement in Poland, back in 1933, to block of Lemkin's attempt to present his paper on Barbarism and Vandalism to the fifth Conference for the Unification of Penal Law in Madrid could be seen as a good example of what we meant by setbacks, by the disappointments faced by such a struggle between the 'real' and the 'ought to have been', between politics and the law, between, perhaps, the forces behind apologia - power politics, perhaps - and the prophets of utopia through the Law. Among other, less relevant for our purposes, points, the paper - that was read out loud even if Lemkin himself was vetoed by the Polish delegation - argued for the inclusion of Crimes of Barbarity and Crimes of Vandalism within the mark of International Penal Law, alongside other heinous crimes such as piracy, slavery and trafficking of women and children.

Barbarism being defined as acts of extermination directed against the ethnic, religious or social collectivises, whatever the motive, such as massacres and pogroms, while acts of Vandalism were, in the definition, associated to the destruction of the cultural heritage of certain collectivities (Shaw, 2015, p.14), i.e. the destruction of its own identity as such. If the former were justified - that is, justified to be put under the label of an International Crime - under the guise of the claim that it would represent a 
threat to world peace and security - in a, truth be told, awfully similar patter under which certain forms of justification towards intervention and war were built upon decades later -, the latter were identified as a sort of crime against the "whole wealth of humanity', that is, it provoked a loss of culture to the whole of humanity in itself and not just to the directly affected group.

While its refusal could be seen as a chilling failure in terms of 'utopia', towards the normativity of International Law against a certain set of behaviours of States, with the images of the recent pogroms still fresh in Lemkin's memory, it was a harsh lesson. The topic would only return on his mind years later, when the Second World War would have already started. While fleeing from Poland to the United States, passing through Latvia, Sweden, a long trip through Russia, Japan, Vancouver and finally admittance to the United States through the East Coast in 1941, the modern prophet seemed to be ready to attempt again to input the notion of what later became 'Genocide' within the Allied statesmen mindset.

From this long way from war-torn Poland to the United States perhaps, for our purposes at least, the most remarkable would be Lemkin's stay in Sweden. His contacts with the Swedes not only allowed for more generous accommodations than in the Baltic States, but also allowed, with the publication of a book in fiscal law with his publisher in Paris, for him to give lectures in Stockholm university on the subject and, finally, to progress on his work against the persecution of certain collectivities. Out of worry of what was happening in occupied Poland, with both his family, acquaintances and his, of course, own people, and recognising the importance of documentation, official memorandum, decrees, newspaper and the like for understanding intentions and, possibly, acquiring useful future information if one were, as he claimed to have been, considering what would it take to spring the allies into more decisive action against what would later be called genocide, Lemkin started to search for, read and collect such official material from both Nazi Germany and the occupied territory in Europe(Lemkin \& Frieze, 2013, p.76). From such material evidence for the intentions for what would later be labelled 'Genocide' were gathered and, eventually, turned into his most famous book, Axis Rule in Occupied Europe published originally in 1944. 
The voyage from Sweden to the United States, in Lemkin's biography, can be argued to have a dual purpose: it not only continues with the narrative in itself, but also serves as an argument of sorts towards the intention of universality within what would later be called "Genocide". For each place that Lemkin narrates his stay, Moscow, the Trans-Siberian railway along its various stops which included the autonomous Jewish oblast of Birobidzhan (Lemkin \& Frieze, 2013, p.87), Vladivostok, Tsuruga, Kyoto, Yokohama, Vancouver, Seattle and, finally, Duke University in North Carolina, the author spends pages describing specific events that he identifies as genocide, most prominently being the slaughter promoted by Mongols of the Golden Horde in Russia roughly in the 13th century or massacres suffered by Christians in the hands of the Japanese in the 17th century onwards. It is interesting to note, however, that in each example given Lemkin is careful enough to demonstrate how each of the cases should be seen not only as massacres per se, i.e as the killing pure and simple of people of a certain group, but as a policy - conscious or not - against certain forms of life and culture, as if to snuff out the existence of said groups, such as Christians in Japan (Lemkin \& Frieze, 2013, p.92-93), in an attempt to defend/promote the cohesion of the favoured, self, group that one identifies with.

This is a tendency that is present in most of the biography, which says a lot in terms of how Lemkin saw his own life. In Duke University, each and every opportunity was taken to advance the cause against Genocide and, then with more fervour, against the persecution and killing of Jews in Nazi Germany and in occupied Europe. While, in the first years in Duke, Lemkin efforts concentrated on trying to convince 'the right people': the people in the network of power of American politics so as to direct the allies to more specific efforts against the ongoing Holocaust: thus Lemkin not only addressed the theme whenever and with whoever it was possible within the academic circles, be it in the discourse he had to give the night of his arrival in Duke during a formal alumni dinner - which he decided to give a narrative of the recent events in Europe and a few characteristics of the atrocities being committed there by the Nazis - be it in the many talks he gave the following months to the North Carolina Chamber of Commerce, women's groups, young people (Lemkin \& Frieze, 2013, p.105), to the US War Department and, finally, to the Board of Economic Warfare, in 
Washington, where he not only got a job but got to meet Henry Wallace, then VicePresident of the United States, on the subject of Genocide (Lemkin \& Frieze, 2013, p.113).

A few weeks later Lemkin had the opportunity to send a one-page memorandum on the topic of Genocide committed by the Axis to President Roosevelt, who responded in a very lacklustre manner, urging for "patience". This disappointment, Lemkin later recalled, was the turning point that made him change strategies to advance the struggle against Genocide: if the politicians usually made promises, if that much, they would far too easily fall back on them and not follow through, especially in topics that did not directly interested them, then the solution, he contended, would pass through informing the general population who could, eventually, pressure politicians. From this point on, and by the perceived need to demonstrate without a shadow of a doubt that not only atrocities, but a very specific crime - Genocide -was happening that the works on "Axis Rule in Occupied Europe" began to take formal shape

\section{5. \\ A few concluding thoughts}

In this chapter, we have attempted to weave together a certain narrative of what was Genocide before Genocide. In other words, as much as "Genocide", as a concept, is the central point of this work in general, we cannot assume it was a fiat, that it came out of nowhere from the vacuum or from the magical inspiration of destiny, of the muses of history or of whatever divinity, secular or not, one may follow.

By considering a certain perceptible mood, a few of the dilemmas faced by International Jurists in terms of what they might have perceived their role to be - in the form of a certain debate of 'power against the Law' that was so common when discussing the League of Nations and its applications -, while also seeing how this debate influenced, shaped and perhaps was shaped by Lemkin with his own possibilities of perception between what the world 'was' and what the world 'ought to be', we hope to have been successful in arguing for a possibility of what might have been a certain space of experience and a certain horizon of expectation of the minds in- 
volved - aware of it or not - in the process of formulation of what later would be understood as 'the concept of Genocide'.

In short, our central disposition here should be seen as an attempt to intertwine what 'Language' was allowed to speak and what kind of reading it made possible to certain kinds of action that disturbed and/or shocked, the interested minds of a few jurists, journalists, and thinkers in the interwar period. The path was not one, directed towards Genocide, but the conditions of possibility, finally, might have been there. With this in mind, perhaps it is time that we consider what Genocide came to be, was supposed to be, or potentially could have been between 1944 and 1948, which is our topic in the next chapter. 


\section{4. Genocide from Axis Rule in Occupied Europe to the Conven- tion}

\section{1.} Introduction

The last chapter can be seen as an attempt to consider what Genocide might have been before it could be associated with "Genocide". In other terms, we have taken into consideration a sort of narrative that may have drawn into what kind of space of experience and horizon of expectation might have existed within the semantic field that permeates a possible definition of "Genocide". As much as there are many possible narratives to what such a space and its projection into the future might have been ${ }^{32}$, the steps under which we proceeded in the previous chapter were directed towards an analysis that not only took into brief consideration what International Law per se took itself to be, ie how certain jurists, journalists, thinkers thought of themselves doing or being capable of doing in terms of International Law and crimes against minorities in the International Milieu, but also how said issues influenced and perhaps, later on, where influenced by Raphael Lemkin's path towards the typifying of Genocide within the International.

This chapter, then, ought to be seen as both a continuation of sorts of the narrative we have started to build based on Lemkin's life and its claimed links towards not only the conceptualization of Genocide but also how he might have actually lived, felt, fought against what it entailed through most of his life, and, on a smaller scale, to consider the place, role and weight of Axis Rule in Occupied Europe (Lemkin, 2008), the military tribunal of Nuremberg and, finally, the process of negotiation and struggle to assume a concept of Genocide within the Convention in 1948.

As previously stated within Lemkin's autobiography, the writing of Axis Rule in Occupied Europe began, perhaps more unconsciously than consciously, in

\footnotetext{
${ }^{32}$ Worth of note, here, would be Schabas (Schabas, 2009) narrative of what came to be known as Genocide in International Law through an analysis a few of the perhaps most important treaties that dealt either with International Humanitarian Law and/or treaties that might have set precedence towards a possible persecution of those involved in Genocide such as the treaties of Sévres, which was never ratified, and later the treaty of Lausanne that substituted it with a controversial amnesty towards the perpetrators of the Armenian Genocide (Schabas, 2009, p.26-27)
} 
Sweden when the author was a refugee in the beginning of the war. That is, the accumulation of evidence towards the general plan of extermination of the Jews by the Germans, through mostly the reading of official decrees in Germany and occupied Europe, began already back in at least 1940. Many of the sources were openly and easily accessed in public libraries in Stockholm, while others were obtained through contacts within the diplomatic corps and friends of the author, while the book itself was written also in Duke University in Durham and in Washington, DC(Lemkin, 2008, p.xiv ; Lemkin \& Frieze, 2013). The book summarises and analyses the rule imposed upon the occupied countries of Europe by the Axis not only in terms of the organisation of these societies within the totalitarian character of their regimes, but, most importantly, how the decrees that govern life and death within such a large area may be seen as good indication towards the Genocidal policy of the Nazi regime (Lemkin \& Frieze, 2013, p.ix).

Due appreciation - and perhaps far too much focus within the Genocide Scholarship, is given to chapter IX, where Lemkin puts forth his definition of Genocide while englobing both previous concepts of Vandalism and Barbarism - is usually seen as the starting point to most studies of what genocide is supposed to be. Yet, I would like to contend in this chapter that not only this initial definition effort is important, but also that it suggests more than a direct, sociological concept of Genocide: it aims to serve as a basis of what Genocide must become - in the conference, years later, surely, but also as an attempt to collect, systematise perhaps, evidences of the intention of nazi policy towards Jews in occupied Europe and, perhaps, to serve as the jumpstart towards a possibility for future trial of war criminals and genocidaires before and during World War Two.

\section{2.}

\section{On the perceptions of the Holocaust viz a viz Genocide}

"Axis Rule in Occupied Europe" became a famous book mostly because of its chapter IX: "Genocide". It is widely accepted as the first instance under which the concept of 'Genocide' was announced, claimed, typified, named, bounded. Most authors would start off by citing the book's definition of Genocide (" By 'genocide' we mean the destruction of a nation or of an ethnic group" (Lemkin, 2008, p.79)) in order 
to either criticise it for not considering factor ' $x$ ' or ' $y$ ' and then suggesting that said factors be included or to praise its broadness or narrowness that allows the inclusion of ' $a$ ' and ' $b$ '. This almost formulaic approach, I would contend, has an outstanding hard time dealing with the politics of (the concept of) Genocide - even if, in itself, it is an exercise on the politics of Genocide. A politics that is brimming, shimmering ever strong, ever present, within the book. In this sense that chapter IX should not be taken in consideration without, at least in part, either the other twenty five chapters or the annexation of the many statutes, decrees and other documents that correspond to more than half of a seven hundred page book.

This is also another way of framing at least a few of the main issues that partakes the Field of Genocide Studies. For a study, such as this one, that takes into consideration the strong ties between the Holocaust and the concept of Genocide might be mistaken as an apology of sorts to the argument for the uniqueness of the Holocaust in terms of what future Genocides might be read as. That could not be further from the truth, or at least from my intentions. The present point when taking into consideration the relationship between Nazi policy, the Holocaust and Genocide within Axis Rule, however, is more akin to the inherent difficulties of dealing with a concept without its roots and origins in terms of meaning and intention. That is, that not necessarily opening up the cannon cases towards other possible cases means weakening the power or the importance of the concept: perhaps more importantly, it means that a concept requires an inquiry in terms of its representation of what might have happened and what it can be possible to expect to happen.

This, however, requires at least a few steps back. If concepts works as joints, or so follows Koselleck's (2004) metaphor, between the possibilities for naming a certain reality and the perception of what that reality 'is', then such movement ought to be noted within Axis Rule. A second step, helplessly intertwined within the first, would be to consider both elements of the book, that is, a definition of what Genocide might have been, and the reading of the events in occupied Europe during World War II. To put it in another way, it might be concomitant to ask how a certain reality might relate to a certain description of that reality through the book - even if ultimately what I call here "reality" is helplessly intertwined in a specific reading of what 
such "reality" might have been. Perhaps, better yet, the - even if slight - changes in terms of intention might have guided and pushed towards the organisation of Axis rule in Occupied Europe in a way and not another. In short, what we will be trying to argue in the next few pages would be that the book, its intentions and argument, changed the way 'Genocide' might have been read as: a compile of documents that seeks to understand whatever was happening in Europe, in order to lend - and certainly receive - strength of argument from a general idea of what genocide could potentially be understood. To accomplish this we might need to continue the narrative from where we stopped.

The gathering of materials for the book began as early as 1940 when Lemkin was a refugee in neutral Sweden. The point of what would later become the book, originally, had a lot to do with the author's own believes in what the Law ought to represent, but it also relates to his own worry over what was happening and would probably happen, in not only occupied Europe but, perhaps more specifically towards Lemkin's background, to Poland itself, his family and the Jewish community that helped him through his escape. There were, mostly, two main sources: Hitler's own idiosyncrasies as summarised as early as the 1920's in Mein Kampf and, perhaps more importantly for our purposes, how such thoughts took shape in the form of laws, decrees, edicts in occupied Europe (Lemkin \& Frieze, 2013, p.76-77). While, according to Lemkin, Genocide has two phases - the destruction of a national pattern of the oppressed group and the imposition of a new pattern, that of the oppressor (Lemkin, 2008, p.79) - they both can be safely indicated, proven even, under the analysis of said documents.

Another way to put the point here would be to understand how deeply intertwined the concept of Genocide in Axis Rule was - is - tied not only to the holocaust itself but also to the whole Nazi intentions and purposes in terms of a post-War scenario. No wonder, in this context, that the concept became almost instantly associated with the Holocaust, being this, perhaps, the origins of the problems and issues that recently evoked calls for "decentring Genocide Studies" (Hinton, 2012, p.5-6).

While the prevailing mood in the International in the aftermath of the War was more than willing to intrinsically link "Genocide" with either "crimes committed 
in the context of the War", as the Nuremberg trials did, or with a certain classification of events that can be almost perfectly matched to the holocaust itself, the scope of the book is certainly broader than that even if it still retains the inherent difficulties that have always been pervading, one way or another, the way under which the Law, and certainly International Law, was thought to be about. In the following pages we'll deal with the problem piecemeal. First, a brief analysis of chapter IX itself, where "Genocide" is conceptualized. Then we'll move on to consider the analysis of the Laws of occupation of the Reich as presented in a few other chapters. The point would be to build a more general argument towards a certain understanding of what "Genocide" might have been at that point.

The drive that turned Lemkin back to his old German documents, stored but partially ignored since his journey from Sweden, was understood to be Roosevelt's and the US government in general, for sure - lacklustre reaction, if not outright apathy towards his narrative of Hitler's regime actions especially, but not exclusively, in Poland. In many was this was a strong disappointment for he who considered - back in 1940 - that "Although the United States was formally neutral, its expression of human concern were warming Europe like the Gulf Stream" (Lemkin \& Frieze, 2013, p.78)

This image - at least within his vision of the government of the United States slowly faded away in a process that began with his work in the Board of Economic Warfare in Washington until his own memorandum to President Roosevelt. The main reason, Lemkin would suggest, for the disbelief on his peers parts would be a remembrance of the exaggeration of the atrocities that the Entente accused the Central Powers of committing especially in Belgium during World War I, as a way of stating that "genocide is so easy to commit because people don't want to believe in it until after it happens" (Lemkin \& Frieze, 2013, p.113).

While it is possible to claim that in part this was a somewhat understandable caution on the allied government, on the other the issue was, perhaps, best summarised by Laqueur (1981) when describing a talk between Justice Frankfurter, of the US Supreme Court, and Jan Karski, a just arrived polish legate. When the latter described what he had recently witnessed in occupied Poland, the first claimed he could 
not believe in Karski. Under protest, he further explained that he was not claiming Karski to be a liar, but that he could not conceive to believe such atrocities to be committed, which he supposed was different than accusing the other as a liar (Laqueur, 1981, p.9).

This reaction reflects on a very common stance on what was happening in $\mathrm{Eu}-$ rope, be either in terms of the German population in general, the citizens of neutral countries such as Sweden and Switzerland, or the people within the Allies and their own government. There is evidence, within the Reich, that the Final Solution was a sort of 'open secret': while never publicly acknowledged by the Nazi Regime it was a constant topic within the government's bureaucratic routine, being spoken to in different codes and metaphors between members of the military and public servants (Laqueur, 1981, p.21-22). It was also, in the very least, incredibly tough - if not outright impossible - to keep the information, or even gossip perhaps, from circulating between the people that lived somewhat close to the extermination camps: not only because the people who worked there had to commute between work and home, but also because the smell and the fumes were, in the very least, impossible to hide (Laqueur, 1981, p.26-27).

In the neutral countries, especially but not exclusively Switzerland and Sweden, both government and population might not have known with certitude about everything but they both certainly 'knew enough' by the summer of 1942 (Laqueur, 1981, p.44). 'Rumors', to say the very least, were spread either through chance - as in the case of a swiss citizen that witnessed the Einsatzgruppen in action in Hamburg (Laqueur, 1981, p.44) - or through newspaper reports, diplomatic courier or the allied information agencies that operated within these countries, through refugees that managed to cross the Alps, and the Committee of the Red Cross (Laqueur, 1981, p.49)

Lemkin was certainly not a lone voice, within the allied countries, against what was happening in Europe. Not only did different branches of government had access to privileged information through either their secret services or, even, through diplomatic service - especially considering the US embassies in Berlin, Budapest and Vichy, which remained open until 1941, early 1942 and late 1942 respectively - but also the press had access to various reports prepared either by the polish resistance 
that did actually go forward to London and Washington - for instance, the Zygielbojm reports and papers (Laqueur, 1981, p.73). From this, follows two considerations that are important for our purposes.

The first reflects the environment against which Lemkin was struggling, that is, the inherent difficulties of not only labelling Genocide as such, but of convincing certain politicians - and, later, the general population - of what was happening in Europe. The second, meanwhile, has to do with the limits of the vocabulary available. At first, as evidenced by the talk between Lemkin and a Jewish baker that gave him shelter for a few days during his escape from Poland, reveals a tendency at first to understand 'what was to come' as a sort of pogrom (Lemkin \& Frieze, 2013, p.52). Or, better yet, we can start to understand the, say, structural element of language through the recurrence of a common, well known, vocabulary as a first effort to understand - and to expect, to predict - certain kinds of events (Koselleck, 1989). The press and the governments agencies, however, once accepted that 'Pogrom' might not simply cut it, adopted general labels such as mass killings, annihilation, mass executions, mass murders, amongst others (Laqueur, 1981, p.75). While certainly not wrong per se, the insufficiency of such terms was well captured and might be considered the whole point of Lemkin's Axis Rule (2008) and, later, the efforts within the 1948 conference.

The cue, in large part, to the importance and need for a 'new term', for the neologism 'Genocide' to appear, Lemkin have argued, would lie in the fact that Genocide not only had 'two phases', i.e. the destruction of a national pattern and then the imposition of a new pattern - when not simply outright elimination of those who have the suppressed pattern -, but it was "the antithesis of the Rousseau-Portalis Doctrine" 33 (Lemkin, 2008, p.80) which is another way of saying that "Genocide", at its core, is independent of the common "war time/peace time" dichotomy in the sense that it is beyond the modern, State-centric conception of War as an institution of sorts, as a few proponents in IR and International Law would argue ${ }^{34}$.

\footnotetext{
${ }^{33}$ Lemkin states the "Rousseau-Portalis Doctrine" refers to the limitation of War against sovereigns and official, regulated and identifiable armies, i.e. war is an activity that must be conducted against sates, not individuals (Lemkin, 2008, p.80)

${ }^{34}$ Cf. Bull, 2002
} 
From this idea of what "Genocide" might be that we can start to understand Lemkin's claims towards the meaning of the war-process in Europe. Or, more specifically, how Nazi Germany seemed to be playing around, linguistically, towards different conceptions and perceptions of what 'war'- 'genocide', in Lemkin's terminology' - really was supposed to be about. This is an argument that can be best appreciated when considering how the author claims to have explained Nazi persecutory policy to Colonel Archibald King of the US War Department that:

it [the Nazi Genocide, or perhaps 'Genocide'] is not a problem of preventing isolated and wanton atrocities even on a large scale, as occurred in Belgium or France in 1914. Hitler intends to change the whole population structure of Europe for a thousand years - which means virtually forever. Certain nations and races will disappear completely or be crippled indefinitely" (Lemkin \& Frieze, 2013, p.109).

If this was a far too dark and terrible machination for the typical civilised ${ }^{35}$ person, as Lemkin claimed when considering the results of his talks with the then vice-president of the United States, Henry Wallace (Lemkin \& Frieze, 2013, p.114), then we might start to understand the thoroughness of Axis Rule in Occupied Europe when considering not only the decrees and rules of occupation but the meaning, objectives and perhaps even 'nature' of a series of German Institutions such as the Police - then almost irreversibly linked with the $S S$-, notions of German Law, of the different forms of administration - that certainly, in many ways, reflected pseudo biological notions of blood and race -, of the different possibilities of Courts and how justice was perceived to be done through them, notions of property, finances, labour and, certainly, the own legal status of the Jews within each of these territories and zones of occupation. Or, in Lemkin's words:

I will publish the decrees spreading death over Europe as an annex to this book. They [the ordinary American] will have no choice but to believe. The recognition of truth will cease to be a personal favor

\footnotetext{
${ }^{35}$ At least as far as Lemkin would understand 'civilisation' to be, and one ought to be very cautious on the reading of such dangerous terminology while keeping in mind the period when said ideas were circulated.
} 
to me and become a global necessity (Lemkin \& Frieze, 2013, p.116).

An affirmation that might be read as not only a statement of what one hopes to accomplish in terms of confronting what would later be labelled as the Holocaust but in terms of bringing to the front and centre the meaning and reality of Genocide in a very specific, and thorough, definition, concept, to the minds and imaginations of people that, at least in Lemkin's perception, might not even consider the possibility of such heinous acts.

There seems to be here, however, an interesting and complex tension between a certain structural idea of what Genocide might be that ought to be important to be pointed out, even if perhaps its proper development might be beyond our own scope, a tension that lies to the very core of the effort to 'decentring genocide' as Hinton called for in a relatively recent paper (Hinton, 2012). In short, we might ask how Genocide, as a series, chains, as a cascade of, as a sort of event(s) cannot fathom to be conceived by 'civilised peoples' and yet, not only to have the crime historically present since antiquity, from the Old Testament and Carthage to, then, the Holocaust ${ }^{36}$ passing through, for instance, the extermination of the native population in the Americas. More than that, it is also to be considered a crime that is inherent to the whole population in general, even if one might, usually but not necessarily, point towards a certain leadership. In other words, the point that we might be raising here can be related to the very possibility and difficulty of closing off, determining, labelling, circumscribing, walling up, a certain notion of what 'Genocide', as such, might be and, finally, the possibilities of its prevention and punishment: in the end, it seems, we are presented with the typical issue of the politics of not only labelling Genocide but also as to who is able, capable or perhaps responsible for it, as it could not otherwise be.

Thus we have the important structure of the argument of Axis Rule: before reading what Genocide is or is not, one is confronted to an analysis that states, for instance, that within the forms of administration employed by the Reich within the occupied territory, one might be facing with situations of what Lemkin called "usur-

\footnotetext{
${ }^{36}$ At least this is rather the point within most of Lemkin's thought, and the very essence of the notion that genocide was "an old crime without a name", as Churchill would later put it, even if this so commonly invoked quote did not refer to the Holocaust, but to the butchering of Russians in the eastern front (Power, 2002, p.30, p.523)
} 
pation of Sovereignty" which might be detected through, for instance, the incorporation flagrante bello ${ }^{37}$ of territory that, de jure, belongs to the invaded nation, by imposing terms such as "the former State of" when, in official decrees and occupant laws, or the imposition of a German pattern of administration in the occupied zone ${ }^{38}$, the introduction of German Law and the changing of other originally local laws (Lemkin, 2008, p.13), which clearly incorporates, throughout the process, both faces of what Genocide ought to have been within Axis Rule: the destruction of specific patterns of life within the occupied group and territory and the imposition of patterns of life of the occupant - while also, once again, being easily referable to more familiar terms to his own audiences, namely, violations of the Hague regulations. ${ }^{39}$.

One might point out at this moment that I employed the term "pattern of life within the occupied group" which could be pointed out as a blatant misreading of Lemkin's definition of Genocide as the "coordinated plan of different actions aiming at the destruction of essential foundations of the life of national groups, with the aim of annihilating the groups themselves" (Lemkin, 2008, p.79, my emphasis). This is partially the point of Schabas (2009, p.30), for instance, when indicating that Lemkin's 1944 definition would be both narrow and broad: narrow in the sense that it was limited to "national groups", broad in that it considered more than just mass killings as potential genocidal acts.

This line of argument, in large measure, could be pointed out as one of the reasons for the path that we have been trodding upon, i.e. to attempt to consider Lemkin's web of thought based on a reading of what might be understood as a certain space of experience that might have either influenced him or that, in the very least, he signalled that it might have influenced him. The point being that if we are to take the broader argument within Axis Rule in Occupied Europe, that is, how Nazi atrocities

\footnotetext{
${ }^{37}$ Latin for "during hostilities"

${ }^{38}$ Consider here, for instance, the Administration by 'Gauleiters", which ruled in areas 'officially' incorporated into the Reich (such as the Sudeten, Malmédy and Moresnet, Austria, Carinthia and a few others), administration by Reich Commissioners and Governors, in nonincorporated but less vital areas such as Denmark and Central Poland and, last but not least, administration by Military Commanders, who answered directly to Hitler, in strategically important areas such as France, Yugoslavia and Greece (Lemkin, 2008, p.10)

${ }^{39}$ Admittedly Lemkin employs the term 'national pattern', but considering his own argument that the German Reich operated not in terms of nations, states, per se but of pseudoscientific notions of race and blood, to state it as 'patterns of life' might not be at all unfair.
} 
operated mostly in terms of certain notions, pseudoscientific ones at that, of blood and race, then we might as well understand the deployment of the term "national groups" in the so often quoted line of chapter IX as more related towards an immense difficulty in naming, labelling what might comprise a group than an overarching argument limiting the possibilities for reading what 'Genocide' might be, or at the least who could be recognised as victims of Genocide. As Shaw (2015) interestingly notes "Genocide, like barbarity, was a comprehensive concept of the social destruction of national groups, and Lemkin believed that it had a very wide applicability" (p.18) which is another way of affirming the 'broad' side of the concept beyond the "more than just mass killings" part of the definition, that is, that the broadness of the concept lies beyond certain patterns of behaviour that might be labelled under 'Genocide': it shows the difficulty in talking in terms of what constitutes a group.

Alongside the choice of deploying "patterns of life within the occupied group and territory" as a sort of terminology lies, too, an important point about the very word itself, "Genocide", as employed by Lemkin that Shaw (2015, p.19) raises: the problem with biology and Genos, that is, within the difficulty in enlisting, admitting, closing off, labelling what a 'group' might be. The problem, as indicated by Levene (2005, p.78-79) lies in the very root of the possible range of meanings within the prefix of "Genocide", "Genos", which could be roughly understood as a group defined through certain notions of race and biology. While any scholar that wants to be taken seriously cannot consider anymore such pseudoscientific notions - and at that Levene(2005, p.79) powerfully argues that not only groups are social but also are socially defined mostly by the perpetrators of Genocide -, I tend to concur with Shaw (2015, p.21) when he suggests that this very ambiguity within Lemkin's employment of race and national groups lies in his main 'study case', that is, in his analysis of what would years later be called the holocaust.

Once more suggesting the blurred and complex relationship between Language and History, between events and the possibilities of narratives that partake ranges of different readings of said events, one cannot be entirely sure, ever, on how much weight the experience of the Holocaust ended up influencing the attempt to give a general name to the crime that later became known as 'Genocide'. Anyhow, 
there might be room for argument that Lemkin did, in Axis Rule, make a mistake of

linking "the general concept of genocide to this secondary feature of the Nazi case" (Shaw, 2015, p.22). After all Lemkin did take great pains to suggest historical instances where Genocide was perpetrated in the widest range possible of situations from Mongolian massacres at the 12th century in Eastern Europe (Lemkin \& Frieze, 2013, p.80), for example, or the butchering of Christians in Japan in the 17th century (Lemkin \& Frieze, 2013, p.92), while also taking in consideration the way the Nazis organised, classified their victims in terms of blood and race.

While Shaw (2015, p.22) summons this whole debate in order to suggest that there is a need, after all, to acknowledge the meaning of 'group' in 'Genos' in the broadest sense possible, the point that I would raise is more related to the intermittent link - and dichotomy - between the limits of language and that which it tries to circumscribe. Or, to be more precise, the general point that I would like to suggest is more a reflection, and in a certain sense a claim, that concepts, after all, cannot help but be based on particular spaces of experience, on certain contingencies that turn a quest for what Genocide "is" - or any polemical concept, to employ Koselleck's terminology - more about certain political dispute, certitude or, perhaps, about the claim of deploying a certain truth in the form of the validated claim towards what a word, a concept, might make reference to. In many ways Lemkin's 1944 definition of Genocide within Axis Rule in Occupied Europe did not escape this predicament. Thus we are presented not only with the borders, the limits of meaning, the inconsistencies that one might find - too broad, too narrow, a little both, none of the aforementioned with whichever concept we attempt to analyse. With this in mind, perhaps, it might be time for us to consider the reception of the Concept in the following months and years until, finally, the Conference in 1948.

\section{3.}

\section{On the reception of Axis Rule and the London Charter}

If Lemkin had tremendous resistance and difficulty with setting forth the concepts of Vandalism and Barbarism in 1933 - he was, after all, impeded from going to the Madrid Conference and had to be content with the paper being floored but not 
discussed - his concept of "Genocide" and the book "Axis Rule" had a better reception in the following years of its publication. In the very least it is possible to claim that the book, and this first utterance of the concept, succeeded in starting the arguably legal, definitely political, debate surrounding what "Genocide" ought to be. In any case it is crucial for us to notice that no matter the definition, its contents, what it covered and what it didn't, the word itself seemed to have caught on. For better or for worse, its adoption can be seen in academic debates - the book was extensively reviewed in a few different fields within the humanities and social sciences -, in legal practice - it was somewhat widely and controversially employed in Nuremberg - and within less specialised audiences - being reviewed, discussed, employed within the general media. We will briefly deal with each in order.

One of the earliest available reviews of Axis Rule was written by none other than John H Herz, considered one of the main scholars of the early field of International Relations in the United States. This sort of background, arguably, can be seen in the emphasis given to the review. Herz (1945) barely glances at the concept of "Genocide", spinning on it the argument that the book would be mainly about the possibly conflicting meanings and consequences for military occupation in wars between different government systems, that is, that the book might be a good step in the direction of a broader discussion in terms of ongoing wars and its post-war scenarios (Herz, 1945, p.366).

It partially brushes aside the concept of "Genocide" by merely quoting its definition as in "Axis Rule", while criticising a few of Lemkin's documentation choices. Such criticism derives from the argument that the inclusion of certain documents to the detriment of potential others would actually defuse the power of the inherent argument in terms of what Herz believes to be the main point of "Axis Rule", i.e, that it is actually a discussion about military occupation and post-war scenarios per se. For instance, the author contests the inclusion of "five rather technical decrees on transportation of goods and persons in the Netherlands" (Herz, 1945, p.367) while omitting "the basic Law of August 23, 1942, on citizenship in Alsace, Lorraine, and Luxemburg" (Herz, 1945, p.367). 
In the end, even while "Genocide" - as a concept - was certainly not that high in probable rank of scholarly interest of John Herz, which might have contributed to what I may argue to be a misreading of Axis Rule in Occupied Europe in terms of its argument and purpose, it might not be unfair to suggest that even the reproduction of the concept as a matter of fact, i.e. as seen and articulated by Lemkin, might have helped to crystallise the term, the word, the concept, within academia ${ }^{40}$.

Merle Fainsod (1945) published a very positive review of Axis Rule in Occupied Europe. Although Cooper (2008, p.62) limits his commentaries of this review on the recognising of the importance of Lemkin's book towards "gathering the essence of this witches' brew" (Cooper, 2008, p.62; Fainsod, 1945, p.744) i.e. in trying to make sense of whatever happened in Europe in the days of Nazi occupation, I would suggest that the review gives a little more than that. Fainsod's points might be understood as - at the very least - essentially three. First, as discussed, the importance of the work per se in order to make sense of the then European situation. Second, the reinforcement of Lemkin's definition of "Genocide" through a necessarily short review of its main points, i.e. how "Genocide", in Axis Rule, may include but is not limited to, physical extermination or the Jews themselves. Third, a brief discussion of an often ignored goal of the book, the proposals for redress". While Fainsod (1945, p.746-747) admits that most proposals, in face of agreements such as Bretton Woods, might be completely brushed aside, there seems to be room for a critique - directed towards both in Axis Rule and in the dealings, actions and decrees of the post-war Victors - of the potential plans towards not only the victims but also - partially - the perpetrators themselves, the point being that the West ought not to answer barbarity with barbarity (in this case, towards Germans) nor avoid attempting to redress the trauma and loss - in the widest sense - to a whole lost generation of Europeans in the face of war and Genocide, a loss that might be, in close accordance with Lemkin's own initial fears that Genocide might bring about - an irreparable loss to each society (Fainsod, 1945, p.747) - and humanity, Lemkin might add.

\footnotetext{
${ }^{40}$ Although the very field of Holocaust, and later Genocide, studies would only flourish much later, to have the concept circulate certainly could not have been a negative thing in Lemkin's general objectives towards a definition and response to "Genocide".
} 
Linden Mander (1945) is another academic that has given a positive review on Axis Rule in term of its potential role for future reference for the study of Law within the Nazi period. More important, however, would be his analysis focusing on a particular element that, wittingly or not, shows a lot in terms of the limits of Language, that is, on the inherent difficulty in prosecuting offenders for a crime that, until then, 'did not exist' or, in the very least, did not have a name. What is meant, in short, is that Mander's (1945) analysis puts forth, essentially, not only the 'invention' of 'Genocide', as a concept, but an attempt to critically link the atrocities committed by Nazi Germany to violations of the Hague Convention beyond the treatment of prisoners, that is, in a way that may smoother the process of judicially persecuting those involved in what would later be known as the Holocaust.

Surely, one has to admit that this line of argument might be a sort of a stretch. Such concerns, commonly summed within the principle of 'Nullum crimen sine lege' ['no crime without law'] were tackled directly within the UN in the aftermath of the Nuremberg Trials by one of its chief prosecutor, Sir Hartley Shawcross, when stated that "the failure of this proposal [the 1933 proposal to declare Barbarity and Vandalism crimes under the law of nations] made it impossible to punish some of the serious Nazi crimes" (Lemkin, 1947,p. 146-147). While it is not unfair to brand it 'a stretch' to input such a foresight back in 1933 or even in 1944 within Axis Rule in Occupied Europe, as Cooper (2008, p.24) does when arguing that after the failure of the Madrid proposal Lemkin left the subject well alone for a while and went on to dedicate himself to his law practice and other less 'polemic' subjects, I would suggest that such a reading, i.e. a reading of Axis Rule in Occupied Europe as an effort to make it juridically easier to persecute those involved in that which was in the process of being labelled as "Genocide", might be possible if, essentially, we consider the linguistic limits of the time when the argument was being made.

What I am trying to argue, in short, would be that even if Lemkin named and defined, within the book, the concept of "Genocide", there was still a need to attempt to make reference to what it might possibly mean, socially and/or juridically, in terms of what was relatively known in the period. That is, even if one might make up a word, "Genocide", and argue that it is - or that it ought to be - a crime under Interna- 
tional Law, it still has to be somewhat relatable to a certain already known International Law, a certain, in short, precedence. Barbarism and Vandalism, in 1933, were often compared to piracy, slavery, trafficking of woman and children (Lemkin, 1947). Not because they are somehow 'similar crimes', but because their juridical circumstances could be seen as relatively close.

The crime of Genocide, in the 1940's, had to be spoken in terms of war crimes à là Hague Conventions. 'In terms of', but not, obviously, the same. This point can be seen in Lemkin's conversation with a certain Colonel King from the US War Department: "To make him understand the concept of Genocide I had to move him a little, unfortunately, from this position" (Lemkin \& Frieze, 2013, p.108). "This", in the quotation, makes reference to the idea that "He was adept in the Anglo-American experimental legal system, and he believed that lawyers of other countries were also basically decent and dedicated" (Lemkin \& Frieze, 2013, p.108), which meant, for the sake of the argument towards explaining Genocide to the Colonel, painting the atrocities of Nazi Germany as a careful, purposeful, and relatively cautious - at least 'cautious' in the way the process was presented, or perhaps 'hidden' is a better word, to/from the World - break from the Hague Conventions stipulations. No wonder, as we will see later, the tremendous difficulty - if one is inclined to refuse the existence of diplomatic/political cold ruthlessness and self-interest - in separating, in dealing with the differentiation between War Crimes and Genocide in Nuremberg.

For the most part it seems that we can start to have a glimpse on the political problem that is carried not only with the concept of Genocide per se, but with most concepts in general, "basic concepts" or not. Genocide - and this point was forcefully driven by Shaw (2013) recently - is an essentially political concept that attempts to hide, or perhaps to surpass, its limits behind a juridical claim to a truth of sorts, or, in the very least, as a concept that inevitably enmeshes itself with examples, actions, readings that never completely relates but cannot be entirely discarded either as forms of experiences, as metaphors even, that helps not only to make sense of what something is supposed to be but also that ends up making part of declaring what something must be within certain forms of narratives that partakes what one might understand as International Politics. As a point, this might become clearer if we keep in mind two 
other reviewers of Axis Rule, published in early 1946. Hans Kelsen (1946) might have been one of the first to suggest the political character that lives deep within the concept of Genocide. This is somewhat clear when he states that Lemkin's analysis "has two objectives: a political and a legal one" (Kelsen, 1946, p.271). The former being a reference to the events, the facts, that are covered by the concept, in whichever area of occupation one might making reference to - in the political, social, cultural, economic, biological, physical existence, religious, or morality fields - while the latter makes a reference to the very possibility of what a punishment to perpetrators might entail as illegal actions under International Law (Kelsen, 1946, p.272).

The politics of the concept of Genocide has not escaped Melchior Palyi, for whom Lemkin "has written what amounts, in effect, to a prosecutor's brief, with the texts of Nazi ukases serving as documents, rather than an impartial - and thereby much more damaging! - inquiry" (Palyi, 1946, p.496). If, on the one hand, this kind of critique can be traced to a certain ideal of what science is supposed to be and to do and doesn't offer much apart from outright discarding a whole author based on his supposed lack of objectivity according to the one that criticises, on the other hand the author offers an interesting input, or at the very least a somewhat of a challenge towards what "Genocide", as a concept, can or should represent. Palyi (1946) ends up making his point in this aspect by asking, roughly, why the Nazi atrocities can be labelled as "Genocide" and actions that he understands as similar, but made by the Allies, ought to slip by, while citing that certain "Allied practices include, in effect, even the worst of Nazi excess - 'genocide', the mass extinction of civilians, as the fate of millions of Germans driven, under inhuman conditions, from their homes in east-central Europe" (Palyi, 1946, p.497).

Surely, one could dismiss such a critique in the sense that 'deportations' under inhuman conditions of Germans in eastern Europe might have more to do with Stalinist Soviet Union - which can easily be fitted under the Genocide label - in a way that ends up absolving a possible guilt by "the West" within the allies, a.k.a. the US, France and Great Britain, but such a dismissal would have trouble to contend with Internment camps of Japanese-American citizens within the US, the Atomic bombings of Hiroshima and Nagasaki or the obliteration of Dresden in 1945. To make my- 
self very clear, I am not in any way attempting to compare each tragedy while looking for which was worse, less worse, or equivalent in some kind of way to the Holocaust, but arguing that the point of the critique can be understood when, and if, we keep in mind that the basis upon which Lemkin made his analysis of the intentions and actions of the Nazi Reich against not only Jews but almost all of the occupied Europe, was made understood through a sort of comparison of possible infringements against the Hague Conventions, which all these examples - Dresden, Atomic bombings, Internment camps - can easily fit into as violations.

In the end, despite the obvious danger of the way the argument is presented, that is, the danger of normalising or, in the very least, downplaying Nazi atrocities under the guise of a claim of lack of scientific rigour "so common among students of law doubling as "social scientists"' (Palyi, 1946, p.496-497), the point of bringing about the political side of Genocide, and the broadening of the concept so as to include Allied atrocities under the roll of Genocide is a fair and perhaps even necessary move.

This sort of uncertainty, or in the very least contingency, of what "Genocide", as a concept, ought to include or exclude was not limited to scholarly discussions. A review on Axis Rule published by Mr. Otto D. Tolischus (1945) on the 21st of January 1945 in the New York Times raises somewhat close, albeit with a different intention, concerns over Lemkin's work. Mr. Tolischus is more likely looking not to World War II but to its aftermath. By far his main concern might not be the concept of "Genocide" per se, but a very liberal critique of the State in the sense that, for him, the danger was not in Germany per se, or the Germans in general as he charges Lemkin of doing - "and he [Lemkin] goes so far as to make the erroneous statements that 'the vast majority of the German people put Hitler into power through free elections" (Tolischus, 1945) -, but what he calls the "Moloch State", i.e. the Totalitarian, centralised State that, through the corruption of the Individual through its subjectification to the all-powerful State might have paved the way for the Genocide to happen. Remarkably the author goes as far as to accuse Lemkin of feeding a "Nazism-inreverse" (Tolischus, 1945,p.1), whatever that might mean. This might be - arguably one of the worst forms of politicization of the concept of Genocide, which ends up 
instrumentalising a possible definition without even the pretence to be acting in a way other than ruthless self-interest - in this case, against the new soon-to-be enemy, the Soviet Union.

Broadening, narrowing, outright ignoring or employing as "Genocide" was in Axis Rule in Occupied Europe might have been a concern, or perhaps a consequence, of not only scholarly circles or the general media, but an extensive concern not only during the negotiations for the establishment of the Nuremberg Trials but also in its deployment, or lack thereof, during the various processes within Nuremberg itself. We'll dwell on them for a while.

This - say - tumultuous relationship between Nuremberg and "Genocide" is quickly presented within Lemkin's narrative. Although the preparations for Nuremberg were mostly crossed out of the autobiography, one of the outlines for "Totally Unofficial", under appendix 6, summarised what chapter 7 should have been, read as follows:

In 1945 I am appointed advisor on foreign affairs to the U.S. War department. I am sent to London as advisor to associate Justice Robert Jackson to assist in the preparation of the Nuremberg Trials. I include genocide as a charge in the indictment (Lemkin \& Frieze, 2013, p.235).

Due in part to the nature of such statement, it is almost impossible to determine the when and where "Genocide", as a category, as a concept, became a topic of discussion between the nations or, even, something that Justice Jackson himself was aware. The topic of an International Military Tribunal came into force, officially at least, within the Conference of San Francisco in April 1945, through the "American Draft of Definitive Proposal" (United States of America, 1949). Although no mention of the word "Genocide" was made, it still did make reference towards bringing into trials major German officers and men "whose offenses have no geographical localization and who will be punished by joint decision of the Governments of the Allies" (United States of America, 1949, p.23).

In early May 1945, President Truman charged Justice Jackson with the task of preparing, and then negotiating with the other Allied Powers, the possibility for conducting a trial of the major Nazi war criminals, a task from which he reported back in 
early june 1945 (King Jr. et al, 2008, p.15). This report, as a first instance of what the Nuremberg Trials ought to cover, is important for at least a few reasons. As stated decades later by one of the prosecutors of Nuremberg, Professor King Jr (2008), this report may not have employed directly the term, the concept, "Genocide", but did in fact name as one of the main crimes to be judged over the committing of "Atrocities and offenses, including atrocities and persecutions on racial or religious grounds, committed since 1933" (King Jr et al, 2008, p.15; United States of America, 1949, p.50).

I would not only concur with such position, but also add that earlier in the report there might be other clues as to the presence of, if not the concept yet, the general notion of what "Genocide" is supposed to be in agreement with the definition presented by Lemkin (2008). More than that, it was a position that made its mark deep within the - say - debate that Mr. Tolischus have raised within his review of Axis Rule in Occupied Europe, namely the conditions upon which "Genocide", as certain actions with certain goals, ought to be reduced to a certain leadership, or if, perhaps, it is plausible to be a charge directed against a whole people. While Lemkin (2008) indeed called for the whole German nation to be of blame, if not for explicit cooperation with the Nazis for outright passivity in front of atrocities and $\mathrm{Mr}$. Tolischus (1945) would dismiss such a proposition since, for him, the problem lies in the Totalitarian State that suppress the individuals' freedom and morals, and thus enables such atrocities, what seems to be at stake between these two positions would be not only the delimitation on whom to trial, but also what role a 'masterplan' would have in face of Genocide. Or, in other words, whether there is a need or at the very least a possibility for identifying a clear intentionality for Genocide.

This is approached by the Jackson report when stated that:

Our case against the major defendants is concerned with the Nazi master plan, not with individual barbarities and perversions which occurred independently of any central plan (United States of America, 1949, p.48). 
Or, in other words, since the proposed jurisdiction of the then would be tribunal would have to limit itself to the Moscow Declaration of $1943^{41}$, that is, that the jurisdiction of the future tribunal would have to be limited towards those major defendants whose crimes could not be geographically determined, then what we have seems to be a sort of understanding that the tribunal would have to be about certain activities that ought to be identified as "Genocide" in so far as they were linked, inevitably, to a certain intentionality from the heads and leaders of Nazi Germany. Just as Lemkin (2008, p.79) has stated in Axis Rule that Genocide would have to be about a certain plan and intentionality to, in the very least, suppress a certain group - physically, culturally, politically, economically, etc - in favour of the oppressor group, it seems that even if the concept was not used, this general idea seems to have been clear on Jackson's report.

These preliminary discussions in San Francisco led to a broader conference on the topic in London, held between June and August 1945, with the initial goal to organise a possible International Tribunal for the major criminals of the European Axis. Considering our goal of - possibly - understanding what Genocide might have meant in a certain moment in time and space, and especially the almost indissoluble link between Genocide and what would later be named as Holocaust, then we might have an argument - or a justification in the very least - for the brief consideration on how and if - (1) a concept of 'Genocide' was formulated within said forum and (2) what would be the possible implications for such a deployment.

Thus we have a few documents to consider before moving to Nuremberg itself. The first being the revision of the American Draft of Proposed Agreement (14th of June 1945). This is arguably the base document that led the entire discussions on the London Conference, a debate that revolved around, mostly, the negotiation and amendment of its clauses. Of the 26 paragraphs we'll have a keen interest in particularly number 12 and number 18 . The former relates to the Declaration of Legal Principles, which can be quoted as:

\footnotetext{
${ }^{41}$ A joint statement made by the then three main allied nations - USA, Great Britain and USSR - that stipulated the commitment to return those germans and officers of the Nazi party, german armed forces, Gestapo or SS responsible for local atrocities and crimes to the countries where such barbarity was committed so that they may be judged by the people they have offended.
} 
12. In any trial before an International Military Tribunal, the tribunal shall be bound by this declaration of the parties to this Agreement that the following acts are criminal:

A. Atrocities and offenses against persons or property constituting violations of International Law, including the laws, rules and customs of land and naval warfare.

B. Atrocities and offense, including atrocities and persecutions on racial or religious grounds, committed since 1 January 1933 in violation of any applicable provision of the domestic law of the country in which committed

C. Invasion of another country by force or threat of force, or the initiation of war, in violation of international law

D. Launching a war of aggression" (United States of America, 1949, p.57-58)

While the latter, which relates to Evidence and Procedure, can be quoted as:

18. An International Military Tribunal shall (a) admit any evidence which it deems to have probative value; (b) confine trials strictly to an expeditious hearing of the issues raised by the charges; (c) disallow action by defendants which will cause unreasonable delay or the introduction of irrelevant issues or evidence; and (d) employ with all possible liberality simplifications of proof, such as but not limited to: requiring defendants to make proffers of proof; taking judicial notice of facts of common knowledge; and utilizing reasonable presumptions (United States of America, 1949, p.59)

There are a few reasons for these two paragraphs being particularly interesting. The first being that number 12 relates, and limits, the kind of crime - and what that crime might have been - that the tribunal itself will recognise, i.e. what the scope, what the limits, of the tribunal will be. If, and part of our argument is that it was, linked to the general idea of what Genocide might have been, then we have a first delimitation of the concept in (International) Politics, that is, a consideration of the concept beyond Axis Rule (2008) and its academic reviewers. The second reason, and this one relates more specifically to paragraph 18 , would be that it helps to direct the terms of the trial within the specifications of paragraph 12 . When suggesting that the 
International Military Tribunal shall "(b) confine trials strictly to an expeditious hearing of the issues raised by the charges" it ends up not only attempting to protect, in a certain sense, the Allied Countries from being charged of hypocrisy, i.e. from judging and condemning atrocities which they might be culpable themselves, that is from allowing the defendants to deflect the accusations by making political moves inside the tribunal against its own legitimacy.

A planning memorandum was distributed to the delegations in the early days of the London Conference as an aid to their understanding of the scope and meaning of the American proposals. Amongst other things, it further specified what the charges within the International Military Tribunal could have been. Said charges were to include, amongst other points, that the defendants launched illegal wars of aggression in 1 September 1939, that such wars of aggression were part of a common plan or enterprise aimed at the establishment of complete German domination of Europe and eventually the world, that said wars of aggression violated various principles of International Law, that atrocities were committed by the defendants during said wars and, perhaps most importantly for our purposes:

(5) That the atrocities and other crimes set forth in subparagraphs (2), (3), and (4) above were committed pursuant to, or in the course of and as the chosen means for executing a common criminal plan or enterprise among the defendants (United States of America, 1949, p.65).

The Memorandum goes further when proposing a certain outline of proof, that is, what proof against the accused ought to include. We ought to highlight paragraph 9 of this section, which states that:

9. Proof of the defendants' atrocities and other crimes referred to in par.1.d(4) above will include but not be limited to the following:

A. Genocide or destruction of racial minorities and subjugated populations by such means and methods as (1) underfeeding; (2) sterilization and castration; (3) depriving them of clothing, shelter, fuel, sanitation, medical care; (4) deporting them for forced labor; (5) working them in inhumane cnoditions 
B. Unlawful expropriations, spoliations and forced sales in occupied areas

C. Unlawful destruction of property

D. Seizure of control of other nations by threats of violence, invasion and other unlawful means ${ }^{42}$ (United States of America, 1949, p.68)

That "Genocide" is present within the outlines of proof is in itself already worthy of note. That it is remarkably close to Lemkin's understanding of Genocide in Axis Rule (2008) is also - to say the least - interesting, albeit understandable if we remember that the author was, indeed, one of the assistants to Justice Jackson in London. What must be stressed here, though, is the way Genocide seems to be interwoven with the very idea of not only war of aggression, but the specific war(s) of aggression occurred after 1933. Considering the necessity of sorts of establishing Genocide with not only legal precedents, but with concrete examples, that is, of previous perhaps inevitable - moves towards explaining what the concept might have meant through certain cases and, more specifically, through the violation of already existing International Law - a.k.a. the Hague Conventions on the Law of War, this ends up becoming a relatively understandable move. More than that, however, to state the outlines of what kind of proof might be acceptable, and under what circumstances, also helps to deal with the political problem as stated in paragraph 18 of the revised American draft, that is, on the possible political challenges that could have arisen during trials, a problem that could not be entirely ignored if we are to remember, for instance, Palyi's (1946) criticism of Lemkin's idea of Genocide and the possibilities for justice in the post-war moment.

Article 12 of the annex of the American proposal would be later adopted, after extensive debate and controversy, into article 6 of the Charter ${ }^{43}$ of the International

\footnotetext{
${ }^{42}$ par.1.d(4) reads: "That before and after the launching of such illegal wars of aggression, and during their continuance, the defendants instigated, committed or took a consenting part in atrocities and other crimes which were in violation of international law or treaties, or the laws of Germany or one or more of its allies, co-belligerents, or satellites" (p.65)

${ }^{43}$ There was a strong controversy between American and Soviet negotiators in relation to the use of the term 'annex'. While the Americans saw no problem on its use, the Soviets, represented in the person of Professor Training, objected to the term 'annex' suggesting that it would not necessarily fit with the idea that it was an integral part of the agreement in itself. The common ground was reached with the term "Charter" (United States of America, 1949, p.186)
} 
Military Tribunal. The definition of "Crimes" was thoroughly discussed and suffered at least ten proposals for redrafting from every delegation. While many would later point out that Nuremberg ended up closing off, or at least attempting to close off, the idea of Genocide by intertwining it with certain notions of War Crimes and, in particular, in crimes of Aggression. This is made clear when we consider Sir David Maxwell Fyfe and Mr. Justice Jackson arguments on the conference session of July 23rd, 1945, where the former declared that "The preparations would in my view include such acts as the terrorization and murder of their [The Germans] own Jewish population in order to prepare for war" (United States of America, 1949, p.329, my emphasis).

This is further developed by Mr. Justice Jackson when he argued that:

The reason that this program of extermination of Jews and destruction of the rights of minorities becomes an international concern is this: it was part of a plan for making illegal war. Unless we have a war connection as a basis for reaching them, I would think we have no basis for dealing with atrocities (United States of America, 1949, p.331).

While, at least solely in this quote, there might be room for an argument that this reflects more a preoccupation of sorts for the legitimacy of the Trials, that is, in a way for accommodating the Nullum Crimen Sine Lege principle, the political reason is made clear by Mr. Jackson himself a few minutes later, when stated that:

We [Americans] have some regrettable circumstances at times in our own country in which minorities are unfairly treated. (...) we think it is justifiable that we interfere or attempt to bring retribution to individuals or to states only because the concentration camps and the deportations were in pursuance of a common plan or enterprise of making an unjust or illegal war in which we became involved (United States of America, 1949, p.333).

In short, perhaps Mr. Palyi (1946) worry on the way the concept of Genocide might be politically used was not unfounded. For while there was originally a sentence in this article that stated that the crimes judged were committed by "the Euro- 
pean Axis", this was dropped ${ }^{44}$ under the argument that it would raise serious concerns of the particularity of the International Law, i.e. it would be seen as "partisan law', in the words of Jackson himself, in the end this limitation can be seen as a somewhat reinstatement of this partisanship for it not only excuses abuses and crimes committed to minorities within the Allied countries, but also excuses such charges, in particular, against detention camps against Japanese Americans during the war, for instance.

As Professor Schabas (2009, p.41) forcefully indicates, this sort of commitment towards something that might be understood as "Genocide" to be equated to War Crimes, or in the very least to be intertwined with a common plan, with the intention to commit Crimes against Peace, crimes of aggression, raised issues that were, mostly, only raised by the French delegation, particularly by Professor Gros who suggested not only that " $(\ldots)$ for the last century there have been many interventions for humanitarian reasons. All countries have interfered in affairs of other countries to defend minorities who were being persecuted" (United States of America, 1949, p.360) but also that it might be dreadfully easy for the defendants to claim that the persecution of the Jews and other minorities were internal policy and had nothing to do with a general plan for waging crimes against Peace, War of Aggression or War Crimes, i.e. the then proposed juridical limits of the International Military Tribunal. Such points were, however, quickly dismissed by Sir David Maxwell Fyfe of the British delegation (United States of America, 1949, p.362; Schabas, 2009, p.41).

In this context, it becomes extremely curious the necessity for the later Protocol of the 6th October 1945, a couple months after the signature of the final London Agreement and the Charter, to correct a discrepancy between the French and English texts against the Russian one. Article 6(c) of the Charter in the French original read as:

C) Les crimes contre L'Humanité: c'est-à-dire l'assassinat, l'extermination, la réduction en esclavage, la déportation, et tout

\footnotetext{
${ }^{44}$ Perhaps 'dropped' might not be the better wording, but 'transferred' might be better: "European Axis" quitted being linked to a certain definition of 'International Law', which Jackson argued would lay the foudnations for a partisan International Law, so that it would be present only in so far as whom the Tribunal would be allowed to put to Trial, that is, the European Axis, not leaving open the possibility for the political accusation against the Allies of committing similar atrocities. This is further explored in Article 18 of the final Charter. Cf United States of America, 1949, p.426-427.
} 
autre acte inhumain commis contre toutes populations civiles, avant ou pendant la guerre; ou bien les persécutions pour des motifs politiques, raciaux ou religieux lorsque ces actes ou persécutions, qu'ils aient constitué ou non une violation du droit interne du pays où ils ont été perpétrés, ont été commis à la suite de tour crime rentrant dans la compétence du Tribunal, ou en liaison avec ce crime (United States of America, 1949, p.429)

As in the case of the English version, which also have employed a semicolon between "war" [guerre] and "or persecutions" [ou bien les persécutions], it was required to swap it to a comma (United States of America, 1949, p.429). Whether on purpose or the mistake of a clerk, to use a semicolon or a comma would radically alters the scope, the range, the jurisdiction of the Tribunal itself: more likely than not, it would have allowed for the condemnation of what would later be associated with 'Genocide' beyond 'Crimes against Peace' or 'Crimes of Aggression', that is, it would have allowed the typification of Genocide 'in peace times' and not only within the barely finished War - and thus, perhaps, the very necessity for the concept itself, or in the very least a conference dedicated to its discussion, would probably have ceased (Schabas, 2008, p.36).

\section{4.}

\section{On the Tribunal of Nuremberg}

While the concept of "Genocide" itself, during the negotiations for Nuremberg, was restricted to the early planning memorandum prepared by Mr. Justice Jackson's staff, "Genocide" came back on the reading of the three counts of the indictment against the accused. The extermination of Jews, that is, the bunk of what Lemkin have been calling into attention during the war years as a Genocide - albeit with the addition that such policy covered more than just antisemitism per se - was made present during the reading of Count one ("Conspiracy, or Common plan to commit Crimes against Peace, War Crimes, and Crimes Against Humanity") was, at that moment, understood within the context of strengthening, preparing the Reich for the wage of said illegal war. As they quoted defendant Ley: "The second German secret weapon is anti-Semitism because if it is consistently pursued by Germany, it will be- 
come a universal problem which all nations will be forced to consider" (IMTN, 1947a, p.34).

Count three of the indictment is usually the most commonly cited instance under which 'Genocide' has been named during the Nuremberg Trials. It states that:

They [the defendants] conducted deliberate and systematic genocide, viz, the extermination of racial and national groups, against civilian populations of certain occupied territories in order to destroy particular races and classes of people and national, racial, or religious groups, particularly Jews, Poles, and Gypsies and others (IMTN, 1947a. p.43-44).

The read of the indictment makes a somewhat clear link, however, between such acts and the general atrocities that are more easily fitted into the categories present in paragraph 6(b) of the Nuremberg Charter, that is, of torture, assassination and the employment of concentration and extermination camps against the general civilian population of the occupied countries, and not only necessary the above "national, racial, or religious groups'. If we keep in mind how Lemkin (2008) insisted, when describing the Nazi Atrocities as a particularly strong case of Genocide, that even if the Nazis felt a strong immediacy against Jews in particular, it did not meant that the Nazi Genocide did not include, in the medium and perhaps long term, the other 'races' in Europe that were not considered Aryans, or at least close enough to what they perceived the Aryan ideal type to be, then we can start to understand such positioning from the Tribunal itself - at least apart from its own necessity of linking the crimes committed against the more familiar jurisdiction of the Hague Conventions.

It is also interesting to note that the third count of the indictment not only suggested the existence of Genocide, but also included a series of acts that would be, at least within Lemkin's work, part of the larger scheme that Genocide 'had to be about'. That is, if Lemkin's Axis Rule identified Genocide as the "the destruction of a national pattern of the oppressed group and the imposition of a new pattern, that of the oppressor" (Lemkin, 2008, p.79), then section (J) of the third count, "Germanization of occupied territories" (IMTN, 1947a, p.63) can be seen on a relatively new light. Or, in the very least, it might be another form of understanding the impending 
link, the imposing link even, between 'Genocide', the Hague Conventions, and ultimately 'War Crimes'.

This link is made even clearer when we consider count four of the indictment - "Crimes Against Humanity" -, while understood as in Article 6(c) of the Charter. In other words, Crimes Against Humanity were here firmly attached to counts one, two and three of the indictment, that is as part of a Common Plan or Conspiracy to commit War Crimes and Crime against Peace. This is made relatively explicit when stated that "The Prosecution will rely upon the facts pleaded under Count Three as also constituting Crimes Against Humanity" (IMTN, 1947a, p.65).

The term itself, "Genocide", was seldom directly employed during the Nuremberg Trials themselves. It was used, explained, cited, defined, in a few different instances: in direct quotation of the concept, we may find statements by Sir Hartley Shawcross, chief prosecutor for the United Kingdom, M. Auguste Champetier de Ribes, chief prosecutor for the French Republic, General Roman Rudenko, chief prosecutor for the Soviet Union, Sir David Maxwell-Fyfe as deputy chief prosecutor for the United Kingdom. The concept was also employed, cynically or not, by Dr. Alfred Thoma, defence councillor for Alfred Rosenberg and by Rosenberg himself in his final statements. However in passing, these deployments might be considered keeping in mind here the sheer size of the Tribunal itself -, as allowing us to have, in the very least, a general idea on not only how the concept did, indeed, 'caught on' but also on the way it was understood to have meant. It is also curious to note that within the Index of the Nuremberg Transcripts (IMTN, 1947f) a series of passages that describes most of the covered sort of atrocities, from more common war crimes such as ill-treatment of prisoners, to slave-labour, internment and extermination camps are usually indicated under the label "Genocide", even when the concept itself did not appear.

When questioning Konstantin Von Neurath during a session on the 25th of June of 1946, Sir David Maxwell-Fyfe stated that:

Now, Defendant, you know that in the Indictment in this Trial we are charging you and your fellow defendants, among many other things with genocide, which we say is the extermination of racial and national groups, or, as it has been put in the well-known book 
of Professor Lemkin, 'a co-ordinated plan of different actions aiming at the destruction of essential foundations of the life of national groups with the aim of annihilating the groups themselves'(IMTN, 1947b, p.61).

Also giving credence to a broader spectrum of Genocide than just outright mass murder, the prosecutor has then followed by questioning the defendant of his policies in Czechoslovakia against the country's Intelligentsia, or “the people who would hand down the history and traditions of the Czech people to other Generations" (IMTN, 1947b, p.61), in the words of Sir Maxwell-Fyfe.

On the 10th of July, 1946, when presenting the defence of Alfred Rosenberg, Dr. Alfred Thoma suggested that:

Rosenberg had, in any case, no ideas of genocide as Raphael Lemkin expounds in Axis Rule in Occupied Europe, page 81, where he [Rosenberg] ends the above quotation after the words 'race and race, people and people' but he [Rosenberg] believe in a struggle between psychologies, in other words, spiritual controversy. (IMTN, 1947c, p.112-113).

This is, to say the least, a dreadfully cynical defence. In this instance, Dr. Thoma makes reference to an excerpt from Alfred Rosenberg's 'The Myth of the 20th Century", a book published originally in 1930 and considered by most as one of the main ideological basis for Nazism. Dr. Thoma, here, blatantly ignores the genocidal potential of stating that

"History and the task of the future no longer mean a struggle between classes, no longer a struggle between Church dogma and dogma, but the dispute between blood and blood, race and race, people and people. And this means: a struggle between psychologies" (as quoted from IMTN, 1947c, p.112) by focusing on 'struggle between psychologies' as if that meant a dispute of ideas that would not spill into violence, while also adhering to a narrow - and wrong as far as Author Intentions go, as I hoped to have shown when presented Axis Rule - interpretation of Lemkin's 'Genocide' that would insist on solely the physical violence side of things. It is curious to note, also, that Dr. Thoma was not the only defendants' council to acknowledge Professor Lemkin's Axis Rule in Occupied Europe. Dr. Gustav Stein- 
bauer, councillor for Arthur Seyss-Inquart, on the 19th of July 1946, called into question the book's legitimacy since it, according to him at least, would falsely attribute the Anschluss of Austria to Seyss-Inquart direct request for German Intervention in March 1938:

We find this historical lie, which has given the defendant the name of 'Judas of Austria' in the story of the Anschluss. We find this historical lie, for instance, in Raphael Lemkin's Axis Rule in Occupied Europe (Page 109) (IMTN, 1947d, p.63)

The concept of Genocide was largely explored during Sir Hartley Shawcross final submission against the defendants on the 26th of July of 1946. Eloquently, the British chief prosecutor not only described the many atrocities committed by the defendants but also that

Genocide was not restricted to extermination of the Jewish people or of the gypsies. It was applied in different forms to Yugoslavia, to the non-German inhabitants of Alsace-Lorraine, to the people of the Low Countries and of Norway. The technique varied from nation to nation, from people to people. The long-term aim was the same in all cases (IMTN, 1947d, p.497)

"Genocide" was also directly employed by the Soviet Chief Prosecutor, General Rudenko, on his final submission. In his words:

And how pitiful are the efforts to dispute the right of mankind to judge its enemies, how vain the efforts to deprive nations of the right to punish those who made enslavement and genocide their aim, and who for many years strove to realize this criminal aim by criminal methods (IMTN, 1947d, p.570).

Rudenko is apparently following a trend somewhat suggested by Lemkin when he tried to pass the concepts of Barbarism and Vandalism. That is, "Genocide" is put right within the jurisdiction of a certain idea of "Crimes against humanity", particularly but not exclusively the crime of slavery: if the latter is punishable by International Law, so should the former. As much as the notion of crimes against humanity, as an argument towards a somewhat universal jurisdiction against the defendants, is summoned, this does not mean a clean break from the notion of Genocide and 
the limitations imposed by the Nuremberg Charter, that is, that Genocide must be understood in the prism of a common plan for the crime of aggression between 1933 and 1945 for

We charge the defendants only with those facts which have been fully established and proved beyond all doubt in the course of the proceedings in which monstrous crimes have been proved, crimes which were prepared over a period of many years by a band of bragging criminals who had seized power in Germany, (...). It has been proved that there existed a Common Plan or Conspiracy in which the defendants participated for the preparation of aggressive wars, in violation of international law and for the enslavement and extermination of peoples. (IMTN, 1947d, p.571).

"Genocide" was also used as an adjective by the British deputy Chief prosecutor, Sir David Maxwell-Fyfe, when describing the Waffen-SS as an organisation that (...) also provided the manpower of the various Nazi genocide organisations operating, within and on behalf of the SS, the Race and the Settlement Main Office, the Office of the Reichskommissar for the Consolidation of German Folkdom, the central office for persons of German race, the personal staff of Himmler, including Siever's infamous Ahnenerbe (IMTN, 1947e, p.225).

To employ it as such is also, in a sense, to consider it as a somewhat common knowledge, that is, to employ the idea of "Genocide" as already clear of what it is for the listeners, without necessarily a need for further elaboration. Genocide is understood as X, and thus it can be automatically associated to certain Nazi organisations, to say the least. This is clarified further when Sir David Maxwell-Fyfe stated that:

In this Indictment is charged not only the murder of millions but a demonic plan of genocide, of the planned murder of whole nations, peoples, and races. The SS was the chosen instrument for this plan which 'outheroded Herod (IMTN, 1947e, p.226).

Perhaps one of the most complete descriptions of what Genocide might be was given By M. Auguste Champetier de Ribes, chief prosecutor for the French Republic, who raised an interesting point when suggesting that: 
And we know what crimes have been committed in the name of this new religion [Nazism], how many dead the realization of this sham doctrine of life has cost: the concentration camps, the gas chambers, and the crematory ovens; the inoculations with viruses, the sterilizations, the vivisections practised on prisoners and deportees, the enslavement of peoples considered assimilable, and above all the methodical extermination of those alleged to be inferior and, in short, "genocide" - all this is the monstrous fruit of the Hitlerite ideology (IMTN, 1947e, p.300)

If anything, this might be one of the first instances that could potentially mud the idea of Genocide advanced by Nuremberg, that is, of Genocide as understood under War Crimes, Crimes Against Peace, and Crimes of Aggression. "Genocide", here, is equated to a series of actions aimed, one way or another, to the elimination of certain groups ("deportees, prisoners, alleged inferiors") for its own sake, or better yet, for the sake of Hitlerism as an ideology. It is possible to understand, in this excerpt, the idea of Genocide linked with Nazism only so far as that was the case being considered by the Tribunal, and not as the defining condition of what one could understand as Genocide. This is made clearer a few moments later, when M. De Ribes stated that

We have shown who those were who were principally guilty of all the crimes of National Socialism. But to realize their diabolical plan of universal domination, not only of territories but of men's consciences, they needed collaborators inspired with the same faith, trained in the same school, and that is why the leaders, the 'Führer', conceived and brought into being, little by little, this complicated and coherent system of leadership, coercion, and control, which constitutes the whole of the organizations of the State and of the National Socialist Party (IMTN, 1947e, p.300-301).

In short, it seems that for M. De Ribes what would be later called "The Holocaust" probably had more to do with a particularity of the ideology of Nazism, while the many acts that made the Holocaust what it was could be named under the label of "Genocide": that is, the concept, here, does not necessarily required a crime of aggression, or perhaps not even Nazism per se. While it certainly did not sway away the 
general idea of Genocide being equated to Crimes of War, Crimes against Peace, Crimes of Aggression within Nuremberg Jurisdiction, we can perhaps start to glimpse on the seeds of dissent of such narrow interpretation of the Concept.

\section{5.}

\section{Genocide at the UN: The road to the Convention}

As Lemkin once stated, "The Allies decided their case against a past Hitler but refused to envisage future Hitlers" (Lemkin \& Frieze, 2013, p.118). That is, while the Tribunal of Nuremberg allowed for the punishment of Major War Criminals of the European Axis, the way it dealt with the idea of what Genocide should be, or, in the very least, what would be the limits for indictment, punishment of certain acts that may be deemed as "Genocide", such limits showed themselves to be wholly insufficient for many in the political, academic and perhaps legal aspect. Or, in other words, while the Tribunal worked as a sort of advancement of a general idea of what can be and what cannot be "Genocide", i.e. which acts, which metaphors, which categories, which history can, or cannot, be associated with Genocide, as a politically disputed Concept - even in its brief years between 1944 and 1946 - it should not come to us as a surprise that already in November 1946 the theme picked up interest - with the due heavy lobbying by Lemkin - in the temporary halls of the just-created United Nations.

If the somewhat debacle of the Madrid Conference of 1933 taught anything to Lemkin, it might have shown in the way he described his bid for the topic to be inserted in the General Assembly Agenda. Recognising the increased difficulty in terms of policy change for Great Powers, while conscious on the importance of speed for the waving of a guilt within most-nations for a post-Holocaust World, that is, sensing a general trend favourable towards humanitarian causes that usually follows from times of barbarity (Lemkin \& Frieze, 2013, p.121), Lemkin set as his targets the small nations, especially if possible from diverse continents - Latin America, Africa, Asia as an attempt to confirm a certain idea of 'universality' within the Concept ${ }^{45}$.

\footnotetext{
45 An idea certainly reinforced throughout his main book, Axis Rule in Occupied Europe (2008), and through his many speeches and talks since his escape from occupied Poland, always stressing how "Genocide" has been happening for centuries in as different spaces as the ancient Mediterranean, the Americas - from discovery to establishment of the United States -, Africa - mostly through colonialism
} 
Thus, between New York's Hotel Lounges and the Delegates Corridor, Lemkin was able to approach and convince the delegations of Panama, Cuba and India to sign a purposely light-weight draft resolution that asked the concept of "Genocide" to be studied by the U.N. in views to be established as an International Crime: in other words, to put the concept within the Agenda of the U.N. General Assembly. Thus doc A/BUR/50 suggested not only the concept to be studied by the ECOSOC ${ }^{46}$ but also associated the concept with outright homicide - as one was to a society, the other was to the individual. This was only the beginning of a long trek that ultimately led to the UN convention in December 1948.

If we were to summarise the road to the convention, we would begin with the concept being put on the agenda of the General Assembly in 1946. The topic would be sent to the Sixth (Legal) Committee of the General Assembly in November 1946, whose draft resolution on genocide would be later adopted by the General Assembly as Resolution 96(I) in December 1946 (Robinson, 1960, p.17). From there the topic was sent to the ECOSOC, who deployed a resolution requiring the Secretary General to undertake studies with the assistance of legal experts with the goal to draft a convention on the crime of Genocide ${ }^{47}$. From there, the Secretariat's Human Right division draw up a draft convention with the help of three legal experts: Professor Raphael Lemkin, M. Henri Donnedieu de Vabres and Professor Vespasian Pella. The first being already familiar to us by his work on the concept of Genocide within Axis Rule in Occupied Europe, the second being important as one of the French judges to the Nuremberg Trials, and the last - alongside the second - as one the of leading figures of the Association International de Droid Pénal which, in the 1920's, led the push towards a "truly international criminal law which would make it possible to punish international crimes" (Segesser \& Gessler, 2005, p.456). From this we have the first Draft of the Genocide Convention ${ }^{48}$.

This first draft was sent for discussion to the UN Committee on the Progressive Development of International Law and tis Codification, which made no specific

- and Asia - with the most common example being Japanese treatment of Christians in the 16th century (Lemkin \& Frieze, 2013).

${ }^{46}$ United Nations Economic and Social Council

${ }^{47} \mathrm{E} / 325$

${ }^{48} \mathrm{~A} / 362$ 
recommendation, and forwarded to the UN member states on the 7th of July, 1947, and then to the ECOSOC's fifth session on the 19th of July, 1947. Through its Social Committee, a further resolution was adopted urging the Secretary General to resubmit the first draft to the member states so as to commentaries, revisions, issues be addressed (Robinson, 1960, p.20-21). The question was deferred, once again, to the Sixth Legal Committee, then to a subcommittee, which ultimately ended up in a Sixth Legal Committee resolution which asked (To the ECOSOC), amongst other things, whether to have a Convention on Genocide or not. This was later incorporated to the UNGA within Resolution 180(II) (Robinson, 1960, p.21).

The topic was taken up by the ECOSOC's sixth session, between February and March, 1948, deferred to the Social Committee, which suggested the ECOSOC to establish an Ad Hoc Committee with the goal to prepare a second draft Convention on Genocide which was to be sent to the ECOSOC's Human Rights Commission and then to the ECOSOC itself (Robinson, 1960, p.23). Between April and May 1948, the Ad Hoc Committee discussed and draft the second draft convention on Genocide ${ }^{49}$.

This second draft convention was discussed in the General Assembly 142nd plenary meeting and deferred to the Sixth Legal Committee on September 301948 , where it was discussed article by article and then deferred to a subcommittee so a final text could be drafted. This text was then discussed by the Legal Sixth Committee between October and November 1948, then sent to a Drafting Committee which reported back to the Sixth Committee on November 23rd, with a final text being adopted and sent to the Plenary Meeting of the General Assembly. It was discussed in the 178th and 179th meetings of the UNGA and, finally, adopted unanimously on December 91948 (Robinson, 1960, p.25-27).

As this brief summary shows, the process of adoption of the UN Convention on Genocide was not only tortuous but a hard fought process in probably each and every step. Nevertheless, we will focus our discussion on comparing the "three drafts", that is, the first draft elaborated by the Secretary General and his legal experts, the second draft as prepared by the ECOSOC and, ultimately, the final Conven-

\footnotetext{
${ }^{49}$ E/AC. $25 / 12$
} 
tion as adopted in December 1948, and the discussions on a few of the many subcommittees where the nitty-gritty details were discussed between the State Members.

It would be Important to note, too, the figure of Raphael Lemkin as force present and to be reckoned with during a good part of the process. More specifically, his narrative partakes his efforts in relation to the adoption of the topic 'genocide' in late 1946, a process that would eventually lead to resolution 96(I) of the United Nations General Assembly, in relation to the behind-the-scenes negotiations that led to the approval, and deferral, of the draft convention from the ECOSOC to the UNGA plenary meeting in late august/early September, respectively, 1948, and, finally, within the tense negotiations during the Sixth Legal and Draft Committee later that UNGA session.

\section{6.}

\section{The Three Drafts and the Convention}

The first steps to the Convention, that is, the process of introducing the topic in the agenda of the UNGA was somewhat unproblematic, at least in terms of its acceptance as a debate. The delegations of Cuba, Panama and India, all of them sponsors to A/BUR/50, introduced the topic in the Sixth Legal committee in terms, unsurprisingly, very similar to Lemkin's Axis Rule. Mr. Dihigo, the cuban delegate, affirmed that Genocide was not a new crime, being committed as it was since antiquity, and that the Nuremberg Trials had failed in the sense that they were too hellbent on Genocide as something practised - or at least punishable - only as linked to war of $\operatorname{aggression}^{50}$ (Abtahi \& Webb, 2008, p.8).

Sir Hartley Shawcross, former British chief prosecutor in Nuremberg, had shown a position that was dreadfully familiar with the negotiations in London, before the Tribunal was established: that is, while he suggested that paragraph three of the then resolution be substituted by a paragraph that states the culpability, the responsibility, of authors, accomplices and, most controversial, States be held responsible. In a somewhat Deja Vu, the French delegation, represented by M. Chaumont, reiterated their position in that debate: States could not be held responsible under French law -

${ }^{50} \mathrm{~A} / \mathrm{C} .6 / 84$ 
but statesmen or private individuals could ${ }^{51}$ (Abtahi \& Webb, 2008, p.11). Just as the crimes of barbarity and vandalism, in 1933, the idea of "Genocide" as an International Crime could inherit protocols [for prevention, for punishment] from other international crimes such as Piracy and narcotics: or, as stated in Saudi Arabia's amendment ${ }^{52}$ ought to enjoy the notion of a universal jurisdiction of sorts (Abtahi \& Webb, 2008, p.7).

The discussion was referred to a sub-committee, as suggested by the French delegation. So as not to get under a quagmire of perhaps irrelevant specificities of the debate, the main point was the confirmation for the need of a draft convention on the subject, that it ought to be done by the ECOSOC under the request of the UNGA. Interesting to notice, however, that the proposal for the issue to be addressed by "a small special committee of jurists to prepare the convention"53 (Abtahi \& Webb, 2008, p.26) was put into the floor, but nevertheless refused in favour of the ECOSOC. These principles were mainly adopted under UNGA Res 96(I) of 11 December 1946.

As discussed as this topic was within the ECOSOC, for our intents and purposes it might be more interesting to direct ourselves towards the first draft of the convention of Genocide, discussed and written by the Secretariat with expert help from Professor Lemkin, Monsieur Henri Donnedieu de Vabres and Professor Vespasian Pella. It is fair to notice how this first draft, in essence, not only shapes up the debate of Genocide within the United Nations, but ends up establishing the limits and possibilities to what must and what must not be included within the topic, in general, of "Genocide". In other words, the range of what is (im)possible to discuss within the later Genocide Studies Field seems to have been, one way or another, dictated - or at least 'captured' - by this first draft.

This is made explicit in the second part of Document E/447, where lies the first draft of the convention alongside commentaries on its production and articles. It states that, for instance, the Secretary-General:

For the rest [of what should be included in the draft] he considered that the first draft to be submitted to the competent organs of the

\footnotetext{
${ }^{51} \mathrm{~A} / \mathrm{C} .6 / 84$

${ }^{52}$ A/C.6/86

${ }^{53}$ A/C.6/120
} 
United Nations ought, as far as possible, to embrace all the points likely to be adopted, it being left to these organs to eliminate what they wished.

In doing so the Secretary-General did not intend to recommend one political solution rather than another, but wished to offer a basis for full discussion and bring out all the points deserving of notice (Abtahi \& Webb, 2008, p.223 my emphasis) ${ }^{54}$

This consideration leaves wide open not only the political role of the Secretariat itself, which common sense might wrongly suggest it to be a bureaucratic, unpolitical function, but essentially the power inherent - conceptually-wise - within the figure of the Secretary-General and, in this case, with the three legal experts to shape up the boundaries of what "Genocide" ought to be understood as. In the next few paragraphs of the commentaries we are faced with perhaps the biggest fear, if not point of contention, that presently still haunts most of genocide scholars that have engaged in conceptual definitions: that "Secondly, if the notion of genocide were excessively wide, the success of the convention for the prevention and punishment of what is perhaps the most odious international crime would be jeopardized"(Abtahi \& Webb, 2008, p.223). This is probably one of the first, if not the first utterance of the "narrow versus wide" conceptual debate.

It is also made relatively explicit, within this draft, somewhat common claims of the capabilities and possibilities of International Law as certain value-free set of principles for the guidance of humankind, in ways that still reflects the dichotomies present not only in the "Apologia-Utopia" argument ${ }^{55}$ but also within certain claims on rationality, logical basis, non-arbitrary opinions with clear cut demarcation between ideas and principles (Koskenniemi, 2005, p.223). This is somewhat contradictory if we keep in mind the very objectives of this first draft while understood as setting the borders, the topics, the range of possibilities; the, perhaps, space of experience and horizon of expectations if we want to somewhat force a point, of the future debates within the many committees and subcommittees of the UN.

\footnotetext{
${ }^{54} \mathrm{E} / 447$

${ }^{55}$ Cf. Koskenniemi, 2005
} 
What, then, are these limits? Under the guise of "Chief Problems involved in the international punishment of genocide", it proposes questions that relates to what a 'group' should represent under the Convention, what 'genocide' itself should meant, about the universality of the convention, about the persons (juridical, physical) capable of committing acts of genocide and, amongst other less important for our goals, who - or what - has the jurisdiction over punishment ${ }^{56}$ (Abtahi \& Webb, 2008, p.224225).

Article I states the purpose of the Convention as preventing the destruction of racial, national, linguistic, religious or political groups of human beings. The term "political", here, raised controversy: Lemkin objected on grounds that its use would be far too controversial at the moment, with the potential to bring down the whole Convention. It was, however, maintained at this early draft on the justification that the Secretary-General "was to submit the widest possible formula" (Abtahi \& Webb, 2008, p.230) for the member-states to discuss. Section 2 of Article I tackles the issues concerning the necessity for intend for some activity to be configured as "Genocide" or, in other words, it attempts to help future politicians, judges, activists, interested parties in general in delimiting frontier of sorts between acts that may be understood as "Genocide" or acts, as reprehensible as they might be, that probably would not fit within a certain concept of "Genocide". Most importantly, it also delineates "three forms" of Genocide, that is, 'physical', 'biological' and 'cultural' genocide.

The first being, perhaps, the most direct, deals with the physical destruction or of injury to their health or physical integrity - in the forms of group massacres, individual executions, experimentations and subjections to conditions that would prevent the survival of members of the group - 'slow death' (Abtahi \& Webb, 2008, p.233). "Biological" refers to limitations towards restrictions of births be it through social, legal or physical means. Perhaps the most controversial of the three would be the last, "Cultural Genocide": Professors Donnedieu and Pella were against this notion, arguing that

cultural genocide represented an undue extension of the notion of genocide and amounted to reconstituting the former protection of

${ }^{56} \mathrm{E} / 447$ 
minorities (which was based on other conceptions) under cover of the term genocide (Abtahi \& Webb, 2008, p.234).

Professor Lemkin, however, was an ardent defender of the admittance of the notion of "cultural genocide", arguing that a group's culture were akin to its value towards civilisation and, as such, it was much more than simply "forced assimilation", but a policy that "aimed at the rapid and complete disappearance of the cultural, moral and religious life of a group of human beings" (Abtahi \& Webb, 2008, p.235). Two points are worth keeping in mind here: first, "cultural genocide" was one of the pillars of the argument within Axis Rule in Occupied Europe, not only in terms of its definition of Genocide per se, but how it ultimately addressed - at least part - of the intent, the 'masterplan', if we are to follow Nuremberg's terminology, behind Nazi policy under occupied Europe. Secondly, for a draft convention that aimed at the notion that "each idea must be properly defined and not overlap others" (Abtahi \& Webb, 2008, p.223), the borders between concepts and ideas, between modus operandi of each case are incredibly blurred. This is not an issue per se if we keep in mind the inherent difficulty, if not outright impossibility, of dealing with "pure", “clean-cut" concepts as if they existed independently of an ultimately messy 'reality', or at the very least a certain reality that dwells on, essentially, uncertainty within the "historical matter" (Koselleck, 1989).

Article II, while dealing with 'punishable offences', delineates further the kind of action that ouch to fit within the idea of "genocide", that is, which are identifiable within the aforementioned categories of Genocide, that, in short, makes reference in terms of what actions falls within the categories of the convention and, thus, are liable for punishment. Namely, attempts to commit genocide, certain 'preparatory acts', wilful participation in acts of genocide, incitement towards acts of genocide, successful or otherwise ${ }^{57}$. The first draft convention also touched on a topic that has been polemical since - at least - Nuremberg, an issue that especially France and England have always been, one way or another, in dispute: the question of who - whether private individuals, public officials, statesmen or even, perhaps, States themselves ought to be punished under the crime of Genocide. While the draft convention pro-

\footnotetext{
${ }^{57}$ Confirming a certain pattern present since the inclusion and conviction of Julius Streicher in the
} Nuremberg Trials 
posed the punishment of private persons - under the charge of 'public incitement to any act of genocide' -, public officials and statesmen, it is worth noting that this was made in dissent to M. Donnedieu de Vabres expert opinion, who suggested that the definition of genocide ought to be restricted to rulers, since - theoretically at least other agents were subjected to domestic law (Abtahi \& Webb, 2008, p.243).

Member-states commentaries to this first draft took long enough as to require at least two requests for comments from the Secretariat and one from the ECOSOC. Even so, not so many member-states to the UN submitted theirs. It is especially worth of note the Venezuelan commentary report ${ }^{58}$ where the delegation suggested that, while a worthy enterprise, the first draft of the convention might present itself as unbecoming due to its partial surrender of Sovereignty in favour of

the establishment of an international repressive jurisdiction which may result in serious danger to Members and wound national feelings that are still over-sensitive ${ }^{59}$ (Abtahi \& Webb, 2008, p.370).

The Venezuelan solution, thus, would involve a return to the 'spirit of resolution 96(I)', since it suggested that anti-genocide legislation be formulated and enforced locally by each country.

The United States also sent forward a set of reformulations of almost every article of the draft convention, of which me might highlight its opposition towards universal jurisdiction (Article VIII), where the U.S. opposed the establishment of a certain rule of law against States that may have not consented to it, that is, to States that refused to ratify the convention (Abtahi \& Webb, 2008, p.377). In a probable jab against the Soviet Union, it also showed support to the inclusion of "political groups" amongst the categories of groups that might be persecuted with genocide intent.

France also raised a series of issues that, ultimately, became staple topics within Genocide Studies. It once again insisted on the punishment of genocide to be meted against rulers, since common agents would more likely be prosecuted under murder charges within domestic law, it suggested the exclusion of the notion of "Cultural Genocide", that Genocide could only be committed with complicity of governments - thus the restriction of punishment to rulers - and, perhaps more importantly,

\footnotetext{
58 A/401/Add. 1

${ }^{59} \mathrm{~A} / 401$
} 
that Genocide ought to be considered in correlation with the Statue of Nuremberg, which might be another way of stating that the crime of genocide can only be committed - or at least indicted - in times of war, perhaps in strict correlation with the crime of aggression (Abtahi \& Webb, 2008, p.383-384).

While a series of wide-raging topics were continuously discussed - as shown through the commentaries of the USA, France, Venezuela amongst others -, the UNGA, the Sixth Committee and the Second Subcommittee limited themselves to question whether a convention was necessary and which forum would be best for it, while the more divisive topics would be addressed by the likely convention (Robinson, 1960, p.21-22). As declared in Resolution 180(II), the UNGA limited itself to request the ECOSOC to continue to study the existent draft convention and eventually to complete it and report back to the UNGA (Abtahi \& Webb, 2008, p.467-468; Robinson, 1960, p.21).

A good part of the responsibility towards this - some would argue - slowness to the matter can be directed towards, amongst others, the representatives of the United Kingdom, Australia and Venezuela. On the Forty-second meeting of the Sixth (Legal) Committee ${ }^{60}$ these delegations suggested, in different forms, the need for a deferral of the question so as to allow more States to lay down their commentaries and opinions on the draft convention. Sir Hartley Shawcross of the United Kingdom, for instance, suggested that questions of jurisdiction, political and cultural genocide were still far too controversial to be put in a ("hasty") convention, jeopardising the whole project. He went further and argued, when citing the problems to be solved in matters of jurisdiction, that

It was highly improbable that any state would be prepared to surrender its citizens, or submit itself for trial by such an international court. What sanctions was such a court to apply? The only real sanction against genocide was war (Abtahi \& Webb, 2008, p.404).

The Australian delegation concurred by suggesting that if a draft convention were to be hastily prepared it would not be adopted, making Nuremberg and poten-

${ }^{60}$ A/C.6/SR.42 
tially Tokyo as the two main precedents for preventing Genocide ${ }^{61}$. Perhaps the Venezuelan statement made it even clearer the issue that not only the delegates were facing, but that would represent most of the challenges of the latter Genocide Studies Field: "It was essential to go beyond the technical stage, which had already been covered by the work of the Secretariat, and to deal with the political aspect of the matter"(Abtahi \& Webb, 2008, p.404). If we consider the essentially political concerns of Lemkin and the other experts, it is doubtful whether they would consider their job as 'technical'. We need only to be reminded of the objectives as stated by the Secretary General within the first draft convention: to be as a general guide to the discussion, not as a final draft with claims linked to certain techniques that presupposes a final answer to the questions of the matter.

As Robinson (1960, p.23) summarises, the discussions that led to the second draft convention, held within ECOSOC's Ad Hoc Committee, evolved around a series of documents, or, in the very least, principles. Of note, we have a Soviet 10-point memorandum ${ }^{62}$, which helped shape much of the early debate. The Committee also had to take into consideration other proposed texts, such as first draft convention made by the Secretariat ${ }^{63}$, a draft made by the United States delegation ${ }^{64}$ and a French draft $^{65}$. While these texts were discussed during the committees meetings, it was decided to use a text proposal by China ${ }^{66}$ as basis for the draft (Abtahi \& Webb, 2008, p.1113).

For our intentions and purposes we'll direct ourselves towards a few of the important differences between the second draft convention as prepared by the Ad Hoc Committee on Genocide ${ }^{67}$ and the Secretariat's first draft convention ${ }^{68}$. If the latter was drafted with the intention of serving as a parameter, as frontier of sorts of the debate - that is, as an argument towards what should or should not be included in the semantic field of Genocide - then the former can be seen as one manifestation of

\footnotetext{
${ }^{61}$ Which, in the very least, would be a daunting perspective considering Lemkin's interpretation of Nuremberg, for instance.

${ }^{62}$ E/AC. $25 / 7$

${ }^{63} \mathrm{E} / 447$

${ }^{64} \mathrm{E} / 623$

${ }^{65} \mathrm{E} / 623 /$ Add. 1

${ }^{66} \mathrm{E} / \mathrm{AC} .25 / 9$

${ }^{67}$ E/AC. 25/12

${ }^{68} \mathrm{E} / 447$
} 
where and how the member-states were willing to go, or at least to limit themselves, within these available frames.

The preamble is already worthy of note. While the first draft considers that Genocide "inflicts irreparable loss on humanity by depriving it of the cultural and other contributions of the group destroyed" (Abtahi \& Webb, 2008, p.214) and that acts of Genocide "are crimes against the Law of Nations" (Abtahi \& Webb, 2008, p.214), the second draft's preamble carries within itself a strong, clear-cut, claim of separating "Genocide" from precedents established by the International Military Tribunal of Nuremberg by suggesting that genocide "is a grave crime against mankind" and that it "has punished under a different legal description certain persons who have committed acts similar to those which the present Convention aims at punishing" (Abtahi \& Webb, 2008, p.1161) .

Here we have the deployment of the idea of a "crime against mankind" instead of the more common "crimes against humanity". As indicated in the debates and reports of the Ad Hoc Committee, this was an intentional move that aimed to clearly server the link between Nuremberg and Genocide. As "Crimes Against Humanity" was used in the tribunal in direct connection to crimes of aggression and crimes against peace, it would be better, so the argument went, not to muddle things even further. It was also following UNGA Resolution 180(II) precedence in its attempt to separate Genocide from other crimes expected to be codified by the International Law Commission ${ }^{69}$ (Abtahi \& Webb, 2008, p.1116). In this context, it is worth pointing out that the preamble was approved despite votes against from the Soviet Union and Poland, who rejected the preamble as present in the second draft convention under the grounds that it did not explicitly link "Genocide" to "Nazi-fascism". While these last considerations were put forth, and rejected by five votes against two, during the first reading of the draft within the committee. One of the main reasons for its rejection was the argument that

while Facism-Nazism [sic] was undoubtedly responsible for the crimes of genocide committed before or during the second world war, it was nevertheless wrong to consider genocide as being an ex-

${ }^{69} \mathrm{E} / 794$ 
clusive product of Fascism-Nazism (Abtahi \& Webb, 2008, p.1074).

While the "protected groups" between both drafts were maintained, "Political Groups" was almost rejected during the second draft, being adopted by four votes against three. The main criticism being the argument that "Political groups" are not only inherently instable but also, and perhaps more importantly, that, according to the Soviet representative, "the inclusion of political groups in the definition of genocide would give the words an extension of meaning contrary to the fundamental conception of genocide as recognized by science" (Abtahi \& Webb, 2008, p.1058). This is a somewhat interesting line of thought, mostly related to a few of the inherent problems within the common scientific discourse, especially but not exclusively while applied within humanities, social sciences or politics in general. It is a line of argument that, in the end, reinforces certain notions of 'closure' that accompany most conceptual discussions, be it within the UN or in scholarly practice.

While the first draft implicitly included the notion of "cultural genocide" within paragraph 3 of Article II, sub-items (c), (d) and (e) ${ }^{70}$, it was decided, within the Ad Hoc Committee, to server the issue from what an act of Genocide might consist and to put it in its own category in Article II of the Second draft convention. The issue was full of contention within the Committee, with arguments in favour suggesting that 'cultural genocide' allows for a full appreciation of the many forms of destroying a group that goes beyond outright killing - which, if left behind, might suggest a failure of a convention aimed to prevent and punish Genocide - while arguments against 'cultural genocide' suggested that "only physical genocide presented those exceptionally horrifying aspects which had revolted the conscience of humanity" (Abtahi \& Webb, 2008, p.1061).

It was also argued that a definition of 'Genocide' that includes 'cultural genocide' would have been even tougher to keep it somewhat clean, since it might blur "Genocide" with matters that, as close as they might be, refers to somewhat different circumstances such as matters of minority protection laws. The approval of "cultural Genocide" within the second draft was a truly close call, with five votes to two in the

\footnotetext{
${ }^{70}$ On the destruction of books, religious shrines and symbols, prohibition of language, amongst other
} issues 
first reading and four votes with three abstentions in the second one (Abtahi \& Webb, 2008, p.1063). If "Political groups" was seen as inherently problematic - as a threat, to use perhaps the better term - by the Soviet Union, a then openly apartheid-like nation like the United States ought to see the inherent threats to a convention that takes into consideration "Cultural Genocide". This is an issue that would come back later not only in the final draft within the ECOSOC and UNGA, but also during the implementation phase (Cooper, 2008, p.189).

Another important point of contention was Article 7 - 'jurisdiction'- of the second draft convention. When the secretariat draft dealt with the issue, it suggested an universal enforcement of municipal law, which is to allow for the trial of an accused of Genocide in any country that has ratified the convention, irrespective of the nationality of the accused. It also called for the commitment of an accused under an international court if (1) their original country was unwilling to trial the defendant or if (2) the defendant was acting under the authorisation/support/compliance of an organ of the state. Such principle, also known as "principle of universal repression" was summarily rejected by the Ad Hoc Committee under the grounds that it would not only undermine a State's Sovereignty but also that it would, through usually politically instigated, and thus biased, trials, generate tension in world politics, i.e. it would allow room for the State of the defendant to charge the country where such trial would be held to "judge the acts of foreign governments" (Abtahi \& Webb, 2008, p.1081). This line of reasoning also served to undermine an old argument that has been constantly repeated at least since 1933: that "Genocide", as an international crime, could be juridically equivalent to slavery, pirating, trafficking of women and children.

The text of the second draft convention was adopted by five votes to one (USSR), with one abstention (Poland) (Abtahi \& Webb, 2008, p.1114; Robinson, 1960,p.24). It was briefly, and incompletely, discussed by the Human Rights Commission and approved without changes by the ECOSOC on the 27th of August, 1948. While this narrative, in Robinson's (1960) analysis seems to be somewhat of a matter-of-fact situation, the ECOSOC meetings on the matter, on the 26 th and 27 th, were the result of an intense lobbying campaign by Lemkin in the months previous to the 
meetings, and the fact that it took only two days for the Draft Convention to be approved - that is, in time for it to be sent to the UNGA in that year's plenary meeting can be considered a gargantuan victory.

Lemkin arrived in Geneva in July 1948, after an invitation from Venezuelan delegate, Ambassador Perez Perozo. Lemkin's plan, then, consisted mostly in gathering as many allies as he could within the ECOSOC and to present the Genocide Convention to the general public through the press. Through his contacts, and a pinch of luck, he was able to talk with ambassadors and delegates from Brazil $^{71}$ and Canada ${ }^{72}$ with the Canadian Ambassador Wilgress being especially crucial in the process since he served as a bridge between Lemkin and the then president of the Assembly, Dr. Herbert Evatt of the Australian delegation. The words Lemkin used to describe his conversation with Dr. Evatt are specially meaningful: "We will work together; I promise to conspire with you and to get the thing through in Paris" (Lemkin \& Frieze, 2013, p.142). That meant, mostly, that Lemkin had not only found a strong ally in the later General Assembly but also within the ECOSOC soon-to-be meetings on the second draft convention, through the strong arguments elaborated by the Australian delegation to the ECOSCO in the figure of Colonel Johnson. Opposition, according to Lemkin, was mostly from the British delegations which aimed to, in the very least, delay a resolution on the matter of Genocide as much as it could (Lemkin \& Frieze, 2013, p.143).

This alliance between Lemkin and Dr. Evatt can be seen through most of the arguments used by the latter in ECOSOC'S two hundred eighteenth meeting held in 26th august, 1948. Dr. Evatt, essentially, hinted of the existence of genocide throughout history, urged for the approval of the Convention in time for it to be discussed by that year's General Assembly plenary meeting in the following month, suggesting that most of the controversies still standing - political groups, international tribunals, Nazi-fascism, cultural genocide, Nuremberg Principles - could be ironed out there ${ }^{73}$ (Abtahi \& Webb, 2008, p.1219-1220), which was not a too far off approach as advocated by Lemkin during his many talks throughout the UN, especially but not exclu-

\footnotetext{
${ }^{71}$ Ambassador Gilberto Amado

${ }^{72}$ Ambassador Leolyn Dana Wilgress

${ }^{73}$ E/SR. 128
} 
sively his arguments to convince Ambassador Wilgress - and Dr. Evatt - just a few days before (Lemkin \& Frieze, 2013, p.141-143). After a brief discussion - and much background lobbying - the second draft of the convention was transmitted to the General Assembly through resolution E/1049, 26 august 1948 (Abtahi \& Webb, 2008, p.1252).

After two years of bouncing around committees in the UN, the discussion on the convention was unanimously - even if with reservations from the United Kingdom Delegation - put in priority in the Assembly's agenda, being, once again, referred to the Sixth Legal Committee. There the second draft convention would be discussed article by article. The main opposition as a whole towards the Convention came in the figure of Sir Hartley Shawcross, who insisted that the Nuremberg Principles were already enough to prevent Genocide and that a further convention would be not necessary.

Lemkin claims that this argument was refuted by a certain Colonel Johnson from the Australian delegation, who fervently denied that "Genocide", as a concept, were to be equal to crimes against humanity as described in Nuremberg, since the latter were necessarily tied to crimes of aggression (Lemkin \& Frieze, 2013, p.144). While I could not find any document to support this narrative, this same argument was made during the Sixth Legal Committee by the Brazilian Delegation, in the figure of Ambassador Gilberto Amado, who suggested that:

While it was true that article 6(c) of the Nürnberg Charter enumerated acts which, by their nature, constituted genocide, such acts were covered by the article only in so far as they came under the jurisdiction of the Tribunal, that is, in so far as they had been committed either during, or in connexion with, the preparation for, war (Abtahi \& Webb, 2008, p.1292).

Since the problems of the convention were already familiar to most delegations during the Sixth Legal Committee discussions, it was decided that the draft would be better discussed within the Sixth Committee itself, and not further referred to the International Law Commission as suggested by the United Kingdom delegation, and that it, then, ought be done in an article-by-article basis (Schabas, 2009, p.79). Article I - which presented a brief definition under the second draft convention 
- revolved around issues that Schabas labelled as 'preambular' - a position reflected on the Indian delegation questioning of the placement of what Article I was then becoming, that is, if it should remain as 'Article I' or included in the preamble ${ }^{74}$ (Abtahi \& Webb, 2008, p.1343) in the sense that "many of the issues were debated twice" (Schabas, 2009, p.80), which is another way of considering the ever present discussion in terms of the nexus between Genocide and crimes against humanity as understood within the Nuremberg Jurisdiction. The issue was solved through the rejection of the Soviet proposal of suppressing article I as article I, and include it within the preamble, and the adoption of the text of Article I as follows:

The High Contracting Parties confirm that genocide is a crime under international law, whether committed in time of peace or of war, which they undertake to prevent and to punish (Abtahi \& Webb, 2008, p.1352) ${ }^{75}$

Article II, in the second draft convention, related to what kind of acts, of deliberate acts, may qualify as Genocide, with the broad topics being "physical" and "biological" Genocide, as well as questions pertaining what kinds of groups ought to be included. For our intents and purposes, there is a specificity within the debates surrounding Article II that must be stressed. In the Seventy-First Meeting, the 11th of October $1948^{76}$, the delegation from the Philippines raised the issue of the possibilities, and consequences, of limiting, constricting perhaps, through the enunciation of certain acts as being acts of Genocide. In his line of thought, the Committee "should avoid enumerating acts, since that would inevitably give rise to limited interpretation" and that "(...) genocide was a new concept, of which history offered few examples, so that omissions would be likely to occur in any enumeration." (Abtahi \& Webb, 2008, p.1365). Of course, to formulate it as such within the UN, surrounded by diplomats, jurists and politicians is to invite a strong reproach. To cite one, we need only to consider the next speech, made by the Mexican delegation, that "it was essential to define the crime as precisely as possible" (Abtahi \& Webb, 2008, p.1365), words that were constantly being reinforced by most of the delegations.

\footnotetext{
${ }^{74}$ A/C.6/SR68

${ }^{75}$ A/C.6/SR68

76 A/C.6/SR71
} 
Wittingly or not, it seems that the delegate of the Philippines had hit the nail on the head, at least in terms of the inherent difficulties in dealing with the problem of Genocide as we have been trying to present it: as the incredible difficulty in bringing forth a certain concreteness towards what the concept is supposed to represent. Or, perhaps in other words, what seems to be at stake would the limits towards the articulation between concepts and the events, instances, metaphors even, that they are supposed to represent - at the same time that the Mexican - and most of the other delegations - response indicates the need, the in many ways inevitable necessity, for achievement of a scientific certitude - if we are to consider the many instances that such wording was employed by the Soviet delegation throughout the whole process ${ }^{77}$ -, that is, a certain claim towards a truth that must be made certain through the social, political, weight that a document, a Convention, carries within itself.

By the end of the discussion on Article II, the argument that 'cultural genocide' might be more akin to minority laws and, as such, ought to be considered within a Human Rights issue spoke louder, which resulted in the drop off of "cultural genocide" from the Convention, a decision that Lemkin considered a bitter defeat he had to endure for the sake of time: with the end of the Assembly on sight, it would put the Convention in jeopardy - at least for approval still in 1948 - to assume another uphill battle (Lemkin \& Frieze, 2013, p.172). Another important issue was the question of "political groups". While it was maintained, at first, within the draft convention sent to the Drafting Committee by the Sixth Legal, and maintained within that Committee, it was dropped in an amendment during the final revision of the then Draft Convention. Lemkin positioned himself firmly against the inclusion of political group under the grounds that

Every revolutionary regime comes to power by destroying some of its opponents. Later this regime is recognized by other nations, sometimes the whole world. Should political groups be included in the definition of genocide, recognition of a revolutionary regime

\footnotetext{
77 The wording "scientific definition of Genocide" was constantly used by the Soviet delegation at least within the ECOSOC's Ad Hoc Committee in 1948 and in the Sixth Legal Committee during the article-by-article consideration of the Draft Convention also in 1948, as seen in doc A/C.6/SR.74, amongst others.
} 
would imply acceptance of genocide as legal (Lemkin \& Frieze, 2013, p.161).

The following articles generated some controversial points, that for our intents and purposes does not add much. They dealt with, mostly, concerns over jurisdiction for the prosecution of the crime of Genocide, towards questions of extradition of accused, questions of interventions - that is, to be able to call upon competent UN organs towards action in view of the UN Charter -, amongst other topics (Schabas, 2009, p.84-86). The final draft was approved by the Sixth Legal committee to thirty to zero votes, with eight abstentions, and sent to the UNGA plenary meeting where it was a briefly discussed in its 178th and 179th meetings. With two Soviet amendments - on cultural genocide and the prohibition of organisations with the genocidal goals being refused, and a Venezuelan amendment being withdraw by its own signatory, the Convention on the Prevention and Punishment of the Crime of Genocide was approved unanimously - with San Salvador and South Africa being absent to the vote on the 9th of December of 1948 (Robinson, 1960, p.27). 


\section{5. \\ Conclusion}

What we have attempted to build in this work was at least one possibility for a conceptual history of "Genocide". If our goal is to understand the political dispute that surrounded the concept of Genocide between 1944 and 1948, then a good proportion of the argument must relate, essentially, to certain conditions of possibility for establishing what Genocide "is" and what it "must not be". That is, as a Concept, we must be able to, in the very least, consider and point towards certain conditions of possibility of a certain history of genocide as to allow us to consider the limits of a manifold debate that have been raging between diplomats, scholars, journalists, activists, and others, for at least the past seven decades.

In essence, what we hoped to have shown would be the conditions of possibility for a debate of what one might assume what a "Genocide" "is" or what a Genocide "cannot possibly be(come)". To put it in other words, to consider a possible space of experience/horizon of expectations that might be a product and producer of what a certain idea of "Genocide" must be, would be the basis upon which we can attempt to understand what is so political and so polemical about "Genocide".

While a good deal of the analysis was based on somewhat already trodden paths, I do believe that the implications of what has been presented here may point in the direction of the complex temporalities that revolves around certain claims towards "Genocide". An Extensive analysis on Lemkin's life have been the object of study of many recent works, amongst which Cooper (2008) is probably one of the most well written. A documentary analysis of "Genocide" within the United Nations is also an almost exhausted topic, with works such as Robinson's (1960), Schaba's (2009) and Lippman's (2002) deserving praise and highlight. The nexus between Nuremberg and the UN Convention was also extensively explored in Schabas $(2008 ; 2009)$ and in King Jr et al (2008).

Take them together, however, and we might have a broader narrative that and this is part of the argument in this work - points in the direction of the different possibilities of what Genocide, as a concept, was, is, must have been, could be: that is, how the many enunciations of the concept, be it in our chosen timeframe or not, 
carries in itself certain claims towards past, present and future - not necessarily in that order. In essence, even if we have been working on a "strict timeline" of sorts, it seems that our point, and its implications, have more to do with the different temporalities that occur (non)simultaneously within the articulation of certain ideas of Genocide than with an overarching claim towards what "is" "Genocide" within the supposedly truth within an (or various) archive(s) where such truth might be understood to be found at.

To make it even clearer, it must be stressed that this is not a relativist argument of sorts of "Genocide" - or a "anything goes", if we are to borrow an anecdotal and perhaps misleading reading of Feyerabend (1999) disposition of science and scientific method. After all, to attempt to build $a$ conceptual history - of Genocide or otherwise - is also to be aware of not only the transcendental critique of a certain idea of scientific truth that might have splashed within the humanities in the 19th century onwards, but also to work through the attempt to consider a movement that - in the very least - tries to extend Heidegger's existential anthropology in order to establish the transcendental conditions of possibility for historical accounts (Zammito, 2004, p.128): or, in essence, to attempt to recognise within concepts - and their complex relationship with possible historical conditions - different forms of temporalities, the manifold layers of time (Zeitschichten) upon which histories can be contained and comprised (Koselleck, 2014, p.25).

Thus we can start to grasp the way the argument of this work has been done: through a possible reconstitution of a space of experience/horizon of expectations that might have surrounded the concept of Genocide through either Lemkin's life and its close relationship with the dichotomies and limits of International Law in the 1920's and 1930's, or through the following negotiation towards what "Genocide" might represent not only in future individual histories that might be assimilated within this general brand - "Genocide" - with all the actions and inactions that it presupposes within itself but also in the possibilities of re-reading certain past events, past histories, past atrocities, within the need for the recourse to historical metaphors so as to make sense of what one might possibly mean by the use of a concept such as "Genocide". 
In the words of Zammito (2004): "The space of experience is the arrayed past for a given present, and the horizon of expectation is the cutting edge of future possibilities for any given present. Each is always in play in every historical event." (p.128-129). With the structure of this work in mind, a few points can be taken from this.

First, this is a good part of the justification behind the very title of this work: $a$ conceptual history and not the conceptual history. Each utterance of the concept carries within itself certain perspectives of a perceived past and an expected future that may or may not come to fruition through the conditions of possibility that this specific utterance carries within itself. The reading of each aspect, of each concept, each possible future and past is determined, in part, by my own reading and, eventually, by the eyes and intentions of those who might brave through these pages.

Second, this process also highlights and justifies the core of the argument within the second chapter. As much as "Genocide", as a concept, or even as a written word, only came to existence, in a way, in Axis Rule in Occupied Europe in 1944, it would be simplistic, if not outright naive, to assume a certain fiat, as if the very processes of apprehension of a certain reality would not be part of the articulation of not only the concept, but - ultimately - the very argument of Lemkin's (2008) book. More than that, however, the need to somehow ground a certain possible perspective, a certain reading on either some linguistic invocations, either the direct pronouncement of the metaphor "Genocide" or the building up of social forces, of interpretations, readings, disputes, ideas that, suffering from multiple focal points, multiple influences in many directions, might have led to a certain idea that, eventually, was linked, described, assumed under the metaphor of, "Genocide".

This does not mean a crashing down of temporality into an overarching present, or as within Gadamer's (1975) answer to the temporal eschatology of Heidegger's Being, of a mode of understanding that might supersede the temporal limits between text and reader, between language and, perhaps, life. Just as temporality seems to be the point of departure between professor and student, i.e. between Gadamer and Koselleck, we ought not to fall trap to either an extreme relativism or a structural determinacy of a correct reading present within the hermeneutical circle 
(Koselleck, 2014, p.108-109). Thus the need for awareness of the temporal conditions so as not to underestimate structural conditions - long term layers -, repetitive but medium term layers, or the category of the event as a brief moment between here and there, the short term layer.

As the argument here unfolds, it is important to stress, the point is neither akin to a Rankean certitude of 'history as it really was' nor to a profound indeterminacy that might obscure completely a certain claim of truth that disciplinary history - as Koselleck (2004, p.206) has argued - usually carries within itself, but more to the point of understanding the possible histories that both enable and are enabled by the ideas that "Genocide" might bring about. This temporal condition is partially illustrated in the second chapter, when we build a narrative on the possible roots on what would later amount to the concept of "Genocide". We might be reminded, for instance, on how Lemkin described his feelings - and it matters little at this point if as an infant or as an adult recollecting his memories while mixing them up with his then recent struggles in the International arena - when confronted with the personal terror of the pogroms in Imperial Russia and his reading of the polish novel by Henryk Sienkiewicz “Quo Vadis?”, first published in 1895: "A line, red from blood, led from the Roman arena through the gallows of France to the pogrom of Bialystok" (Lemkin \& Frieze, 2013, p.17). If anything, this line is especially interesting for it allows us to consider not only the many layers upon which an experience of terror, of dread, and, essentially, of massacre might not only be sensibly perceived, but also compared, collided even, against then contemporary issues that pervaded the everyday life of Lemkin and his family.

This might not be a necessary condition per se for the concept of Genocide itself, but the juxtaposition of individual histories, for instance the pogrom's in the early 20th century, or the intricacies of the trials of the murderers of men responsible for dreadful atrocities - such as the trial of Songhomon Tehlirian or the trial of Samuel Schwartzbard -, along with a general confidence, in the 20's and 30's, on the power of International Law and institutions to keep peace and justice in the world might have more than just helped to hatch the idea that certain forms of massacre had to be named, branded, outlawed and thus prevented. Herein the importance of the push 
towards the Crimes of Barbarism and Vandalism, which were clearly not - to put it in simple terms - 'yet enough' for "Genocide”, as a concept. It would require, it seems, the forces of acceleration that the atrocities against the Jews in the Nazi Holocaust, a few years later, to provide a general mood for a Genocide Convention, which partially explains the line of the argument in this present work: from barbarism and vandalism, Genocide in Axis Rule, to Genocide in the news, to Genocide in Nuremberg, to Genocide(s) in the United Nations and so it goes.

What this choice also reveals, it seems, would be the possible novelties and continuities in terms of efforts to argue for a specific understanding of what "Genocide" might - or might not - be about. Thus through all these instances a few metaphors seems to be always returning, while others present themselves as a somewhat radical break from past representations of how things must or must not be in International Politics. In terms of jurisdiction, for instance, the comparison with crimes such as piracy, slavery and human trafficking is almost perennial, appearing at first when considering the crimes of Barbarity and Vandalism (Lemkin \& Frieze, 2013, p.23), and later in the UN, within the initial discussions towards considering Genocide to be included in the UNGA agenda in 1946 (Abtahi \& Webb, 2008, p.7).

It might be fair, thus, to understand the main argument of this work as a thrust into understanding, or at the very least indicating, a few of the stakes behind most discussions and debates towards what "Genocide" "is", towards what kind of event, what kind of medium term processes or even long term structures might be safely associated with a certain idea that "Genocide" must, one way or another, bear. In other words, while the point here does not cut into the argument towards one way of understanding Genocide against another in very concrete terms, that is, it does not explicitly assumes a position between the age old arguments towards and against "narrow" understandings or "broader" understandings of "Genocide", I do hope to have made clear my position towards this politicisation of the Concept as not only of its inevitability or but also of their metaphorical limits as set in stage not only between 1944-1948 but, inevitably, whenever the "Genocide" label is invoked under certain circumstances. 
Thus we are continuously facing somewhat familiar questions whenever atrocities are caused. Be it through the what Hinton calls "core", "second circle", "periphery" or even "forgotten" genocide cases (Hinton, 2012, p.12), the point seems to always be related to how a certain instance, a certain circumstance might, or might not, relate to a specific notion of what "Genocide" "is". There seems to be at least two consequences for that: first, we might be caught up in a somewhat - and perhaps cynically intended - eternal debate within the UN or other international forums if a specific ongoing situation 'is' or 'is not' Genocide, a situation that not only leads to justified frustration towards inaction in face of atrocities (Beardsley, 2011), or, second, we might be facing certain forms of questions that strike at the very heart of disenfranchisement within our political communities, that is, the bringing forth of situations, living conditions, events, forms of exclusions and inclusions that take place at the centre of how certain society understand itself.

To have a glimpse on what is meant by that, it might be useful to consider, for instance, a recent statement by the current - as of early 2017 - UN special adviser on the Prevention of Genocide, Mr. Adama Dieng, according to whom:

Following attacks by armed assailants against border security posts in October 2016, the response of the military [of Myanmar] has reportedly been characterized by excessive use of force and other human rights violations against civilian population, particularly the Rohingya Muslim population, including allegations of extrajudicial executions, torture, rape, and the destruction of religious property (UN, 2017).

While this statement on the current situation of the Rohingya minority within Myanmar explicitly avoids the use of the term "Genocide", the situation being assessed by the UN special adviser on the Prevention of Genocide, and the very description of the problem, a few paragraphs later, as an instance where

the current violence did not come out of thin air. It is taking place against a background of very deeply rooted discrimination against specific sectors of the population and a failure to put in place conditions that would support peaceful coexistence among different communities in Rakhine State (UN, 2017). 
This gives us a good peek into possible consequences, possibilities, and political weight even behind what it might mean to assume what can or cannot, what is viable or not to be understood, to be caught on, the label of "Genocide".

We do not have to wander far, however, to be painfully aware of the political dispute, of the political weight, that carries the usage of a concept of Genocide, as a stable enough concept so as for us to understand what one might mean when one frames a certain event, a certain structure, as such, but also still politically polemical enough so as to allow for a manifold, layered, understanding of the concept. It is, for instance, largely employed in Brazil as a framework to make sense of the current and historical - situation of essentially disfranchised groups, that is, poor, black communities, that is, the African diaspora through the articulation of claims towards a genocide of the black populations in Brazil.

Although the concept has gained more prominence recently through a report by a Comissão Parlamentar de Inquérito (CPI) that stated the occurrence of a Genocide against the Black population in Brazil (Brazil, 2016), the usage of "Genocide" as a political claim against certain events and structures that indicated not only inequality and injustice in the broadest sense possible, but also of outright - even if somewhat masked by official discourse - extermination of Black population is not exactly recent, with authors such as Abdias do Nascimento (1978) deserving highlight.

The point is also appreciated by Vergne (2013) when justifying the use of Genocide in his work:

I use Genocide as processes and every day practises that are based on a wish for the elimination, or of estranging of the other, that consents, even if silently, in his elimination. What I propose is to think the effects of said wish in the everyday of the Brazilian society, especially in the everyday life in Rio de Janeiro" (Vergne, 2013, p.33-34, highlights in the original)78

If we have been speaking mostly in terms of the possible temporalities and meanings that a certain concept of Genocide might assume, then the above circum-

\footnotetext{
${ }^{78}$ My translation from the original: "Utilizo genocídio, como sendo o efeito de um conjunto de práticas cotidianas baseado no desejo de eliminação, ou de afastamento do outro, consentindo, mesmo que silenciosamente, em sua eliminação. Proponho pensar os efeitos deste desejo no cotidiano na sociedade brasileira, especialmente na vida cotidiana do Rio de Janeiro"
} 
stances can be understood as a continuation of sorts of a process that might have started somewhere around 1944, but did not - as it cannot - reach its end in terms of a scientific, exact, definition of what something, Genocide, is as a few might advocate. Thus we are presented with at least a few of the difficulties that are inherent to a process of politicisation of a concept: the subjectivity that limits what one may or may not perceive, understand, read, announce - grammatically - as an event, as an experience, as a sort of truth, the very (grammatical) traces under which such readings, announcements and what not must not only be based upon but also ought to, one way or another, deviate from. That is, the inherent difficulty in inserting some sort of novelty within a - linguistic or otherwise - structure. If we circle back to the 'intentionalists' and 'functionalists' debate in terms of the Holocaust (Bloxham, 2009, p.305-314) then we might better appreciate what might be taken to be new within the contentiousness, within the range of possibilities of what "Genocide" "is" or what it "cannot, possibly, be": the terms of the debate becomes not only incredibly familiar, but also one might start to see the inherent problem of closing off, through scientific claims of truth or not, what "Genocide" "is".

Points one and two may also, respectively, refer to the ever present notion of punishment and prevention. Especially in the latter case, it is crucial that we ask ourselves what would be the stakes on claiming a certain boundary towards the concept of Genocide. True enough, there has been plentiful of arguments towards the difficulties inherent within claims for humanity, or a human group, that is in essence allembracing, i.e. devoid of some sort of fault line, of a suture that works through and within certain categories of borders (Salter, 2014). Or, perhaps, arguments that indicates and traces certain possibilities - or, perhaps, necessities - for processes of inequality not only in the International, whatever that may be understood as, but, essentially statements about equality/inequality within the idealised human grouping as understood in International Relations, the State itself (R. B. J. Walker, 2002). Processes, in short, that are also partially understood as two of the ontological conditions for "history(ies) to happen" within Begriffsgeschichte: relations between above and below, inner and outer, which forms what one might call the prelinguistic conditions 
for history which, on extreme forms, might as well be seen with all its genocidal potential (Koselleck, 1989, p.651).

Thus we circle back to the eternal dispute of "narrowing" versus "broadening" Genocide and the main argument towards a conceptual history of Genocide. Between Axis Rule, its critical reviewers, editorial posts in the newspapers, Nuremberg and the manifold articulations within the UN we seem to have in front of us the inherent difficulty in nailing down in reality, whatever that may be, the definitive, atemporal, meaning of a certain concept. This, once again, is not to argue for a relativism of the concept that might undermine any possibility of prevention and punishment, but to consider a multi-layered temporal condition for a concept to exist is also to take seriously not only the many forms upon which a concept might be employed, but, essentially, the very processes upon which said forms are disputed, formed, framed, discarded, bounded. Or, in other words, the very approval of the Convention cannot, should not, be seen as a closing point on the debate, which, as a movement, is another way of highlighting the importance of the at least twenty-one different conceptualizations of Genocide between 1944 and 2001 that Straus (2001) indicates. Each utterance has a meaning towards a perceived past and imagined future, concurring, contradicting, arguing for and against, improving or ultimately changing other forms upon which not only "Genocide", but also the kind of events that each conceptualisation makes reference to. Failure to appreciate the inherent, multi-layered value of each concept of "Genocide" might, in essence, mean a failure on indicating what one is supposed to Prevent - or punish, for the matter. 
6.

\section{Bibliography}

ABTAHI, H.; WEBB, P. The Genocide Convention: the travaux préparatoires. Boston: Martinus Nijhoff Publishers, 2008 1v.

. The Genocide Convention: the travaux préparatoires. Boston: Martinus Nijhoff Publishers, 2008 2v.

BAUMAN, Z. Modernity and the Holocaust. Ithaca, N.Y.: Cornell University Press, 1989

BEARDSLEY, B. The Endless Debate over the 'G Word'. Genocide Studies and Prevention v.1, n.1, p.79-82, 2011

BELL, D. S. A. International Relations: The dawn of a historiographical turn? The British Journal of Politics \& International Relations, v.3, n.1, p.115-126, 2001

BLOXHAM, D. The Final Solution: A Genocide. Oxford: Oxford University Press, 2009

BLOXHAM, D.; MOSES, A. D. (Orgs.) The Oxford Handbook of Genocide Studies. Oxford: Oxford University Press, 2010.

BRAILSFORD, H. N. The Covenant of Peace: an essay on the League of Nations. New York: B.W. Huebsch, 1919

BRASIL. Senado Federal. Relatório Final CPI Assassinato de Jovens, 2016. 155p.

BRAUDEL, F. The Mediterranean and the Mediterranean World in the Age of Philip II. Berkeley: University of California Press, 1995

BULL, H. The Anarchical Society: a study of Order in World Politics. 3. ed. Basingstoke: Palgrave Macmillan, 2002

BULL, H. WATSON, A. (Orgs.) The Expansion of International Society. New York: Oxford University Press, 1984

CARR, E.H. The Twenty Years' crisis, 1919-1939: an Introduction to the Study of International Relations. London: Macmillan and Co., 1940

CARVALHO, B.; LEIRA, H.; HOBSON, J. M. The Big Bangs of IR: The Myths that your teachers still tell you about 1648 and 1919. Millennium - Journal of International Studies. v.39, n.3, p.735-758, 2011

CÉSAIRE, A. Discourse on Colonialism. New York: Monthly Review Press, 1972 
CHALK, F. R.; JONASSOHN, K. The History and Sociology of Genocide: Analysis and Case Studies. New Haven: Yale University Press, 1990

CHARNY, I. W. How can we commit the unthinkable: Genocide, the human cancer Boulder: Westview Press, 1982

COOPER, J. Raphael Lemkin and the Struggle for the Genocide Convention. Basingstoke: Palgrave Macmillan, 2008

ELMAN, C.; ELMAN, M. F. (Orgs). Bridges and Boundaries: Historians, Political Scientists, and the Study of International Politics. Cambridge, Mass.: MIT Press, 2001.

FARR, J. Understanding Conceptual Change Politically. In: BALL, T.; FARR, J.; HANSON, R. L. (Orgs). Political Innovation and Conceptual Change. New York: Cambridge University Press, p.24-49, 1989

FEYERABEND, P. Theses on Anarchism In: MOTTERLINI, M. For and Against Method: including Lakato's lectures on scientific method and the LakatosFeyerabend correspondence. Chicago: Chicago University Press, 1999

GADAMER, H. G. Truth and Method. New York: Seabury Press, 1975

GUZZINI, S. The ends of International Relations Theory: Stages of Reflexivity and modes of Theorizing. European Journal of International Relations. v.19, n.3, p.521-541, 2013

HINTON, A. L. Critical Genocide studies. Genocide Studies and Prevention. v.7, n.1, p.4-15, 2012

HOBDEN, S.; HOBSON, J. M. (Orgs) Historical Sociology and International Relations. New York: Cambridge University Press, 2002

HOBSON, J. M.; LAWSON, G. What is History in International Relations? Millennium - Journal of International Studies. v.37, n.2, p.415-435, 2012

HOROWITZ, I. L. Taking Lives: Genocide and State Power. 3 ed. London: Transaction Books, 1980

IFVERSEN, J. About Key Concepts and How to Study Them. Contributions to the History of Concepts. v.6, n.1, p.65-88, 2011 
IGGERS, G. G. The German Conception of History: The National Tradition of Historical thought from Herder to the Present. Middletown, Conn.> Wesleyan University Press, 1983

INTERNATIONAL MILITARY TRIBUNAL NUREMBERG. Trial of the Major War Criminals before the International Military Tribunal. Nuremberg, Germany, 1947a 1v.

Trial of the Major War Criminals before the International Military Tribunal. Nuremberg, Germany, 1947b 17v.

. Trial of the Major War Criminals before the International Military

Tribunal. Nuremberg, Germany, 1947c 18v.

. Trial of the Major War Criminals before the International Military

Tribunal. Nuremberg, Germany, 1947d 19v. . Trial of the Major War Criminals before the International Military Tribunal. Nuremberg, Germany, 1947e 22v. . Trial of the Major War Criminals before the International Military Tribunal. Nuremberg, Germany, 1947f 23v.

JOHNS, F.; JOYCE, R.J.; PAHUJA, S. (Orgs). Events: the Force of International Law. New York: Routledge, 2011

JONES, A. Genocide: A comprehensive Introduction. 2 ed. New York: Routledge, 2011

JORDHEIM, H. Against Periodization: Koselleck's Theory of Multiple Temporalities. History and Theory. v.51, n.2, p.151-171, 2012

KAEMPFFERT, W. Genocide is the New Name for the Crime Fastened on the Nazi Leaders New York Times, New York, p.E13, 20 oct, 1946

KELLY, M. J. Genocide - The power of a Label. Case W. Res. J. Int'l L. v.40, n.1, p.147-162, 2008

KING JUNIOR, H. T.; FERENCZ, B. B.; HARRIS, W. R. Origins of the Genocide Convention. Case W. Res. J. Int'l L. v.40, n.1, p.13-34, 2008

KOSELLECK, R. Critique and Crisis: enlightenment and the pathogenesis of modern society. Cambridge, Mass: MIT Press, 1988 
. Linguistic Change and the History of Events. Journal of Modern History. v.61m n.4, p.650-666, 1989

Uma História dos Conceitos: problemas teóricos e práticos. Estudos Históricos. v.5, n.10, p.134-146, 1992

.. Some Reflections on the Temporal Structure of Conceptual Change. In: MELCHNG, W.; VELEMA, W. (Orgs.) Main Trends in Cultural History: Ten essays. Atlanta, GA: Rodopi, p.7-16, 1994

A Response to Comments on the Geschichtliche Grundbegriffe. In: LEHMANN, H.; RICHTER, M. (Orgs.) The Meaning of Historical Terms and Concepts: new studies on Begriffsgeschichte. Washington, DC: German Historical Institute, p.59-70, 1996

. Estratos do Tempo: Estudos sobre História. Rio de Janeiro: Contraponto,

2014

The Practice of Conceptual History: timing history, spacing concepts.

Stanford, Calif.: Stanford University Press, 2002.

. Futures Past: on the Semantics of Historical Time. New York: Columbia University Press, 2004

KOSELLECK, R.; RICHTER, M. Introduction and Prefaces to the Geschichtliche Grundbegriffe. Contributions to the history of Concepts. v.6, n.1, p.1-37, 2011

KOSKENNIEMI, M. The Gentle Civilizer of Nations: the rise and fall of International Law, 1870-1960. New York: Cambridge University Press, 2002

From Apology to Utopia: the structure of international legal argument. New York: Cambridge University Press, 2005

. The Politics of International Law. Oxford: Hart Publishing, 2011

KUPER, L. Genocide: its political use in the twentieth century. New Haven: Yale University Press, 1981

LAQUEUR, W. O Terrível Segredo: a verdade sobre a manipulação de informações na "Solução Final” de Hitler. Rio de Janeiro: Zahar Editores, 1981

LAWSON, G. The Eternal divide? History and International Relations. European Journal of International Relations. v.18, n.2, p.203-226, 2012 
LEMKIN, R. Axis Rule in Occupied Europe: Laws of Occupation, Analysis of Government, Proposals for Redress. Washington: Carnegie Endowment for International Peace, 1944. Resenha de: FAINSOD, M. Harvard Law Review Association. v.58, n.5, p.154-157, 1945

Axis Rule in Occupied Europe: Laws of Occupation, Analysis of Government, Proposals for Redress. Washington: Carnegie Endowment for International Peace, 1944. Resenha de: HERZ, J. The American Political Science Review. v.39, n.2, p.366-367, 1945

Axis Rule in Occupied Europe: Laws of Occupation, Analysis of Government, Proposals for Redress. Washington: Carnegie Endowment for International Peace, 1944. Resenha de: KELSEN, H. California Law Review. v.34, n.1, p.271272,1946

Axis Rule in Occupied Europe: Laws of occupation, analysis of government, proposals for redress. 2 ed. Clark, N. J.: Lawbook Exchange, Ltd., 2008 (1944) Axis Rule in Occupied Europe: Laws of Occupation, Analysis of Government, Proposals for Redress. Washington: Carnegie Endowment for International Peace, 1944. Resenha de: MANDER, L. A. The American Historical Review. v.51, n.1, 1945

Axis Rule in Occupied Europe: Laws of Occupation, Analysis of Government, Proposals for Redress. Washington: Carnegie Endowment for International Peace, 1944. Resenha de: PALYI, M. American Journal of Sociology. v.51, n.5, p.496-497, 1946

Axis Rule in Occupied Europe: Laws of Occupation, Analysis of Government, Proposals for Redress. Washington: Carnegie Endowment for International Peace, 1944. Resenha de: TOLISCHUS, O. D. Twentieth-Century Moloch: The Naziinspired Totalitarian State, devourer of Progress - and of Itself. The New York Times, New York, p.1, 24. 21 jan 1945

Genocide as a Crime under International Law. The American Journal of International Law. v.41, n.1, p.145-151, 1947

LEMKIN, R.; FRIEZE, D. L. Totally Unofficial: The autobiography of Raphael Lemkin. New Haven: Yale University Press, 2013 
LEVENE, M. Genocide in the Age of the Nation-State: The Meaning of GenocideThe Meaning of Genocide. New York: I. B. Tauris, 2005 1v.

LIPPMAN, M. A Road map to the 1948 Convention on the Prevention and Punishment of the Crime Genocide. Journal of Genocide Research. v.4, n.2, p.177-195, 2002

MARCHART, O. Post-foundational political thought: political difference in Nancy, Lefort, Badiou and Laclau. Edinburgh: Edinburgh University Press, 2007

MORGENTHAU, H. J. International Affairs: the Resurrection of Neutrality in Europe. The American Political Science Review. v.33, n.3, p.473-486, 1939

MOSES, A. D. The Holocaust and Genocide In: STONE, D. (Org). The Historiography of the Holocaust. New York: Palgrave Macmillan, p.533-555, 2004.

NASCIMENTO, A. O Genocídio do Negro Brasileiro: Processo de um Racismo Mascarado. Rio de Janeiro: Editora Paz e Terra S/A, 1978

OLSEN, N. History in the Plural: an introduction to the work of Reinhart Koselleck. New York: Berghahn Books, 2012

POLlARD, A. F. The League of Nations, an Historical Argument. Oxford: The Clarendon Press, 1918

POWER, S. A Problem from Hell: America and the age of genocide. New York: Basic Books, 2002

RAVAL, M. (Org). Rainer Maria Rilke: his last friendship. New York: Philosophical Public Library, 1952

RICHTER, M. Begriffsgeschichte in Theory and Practice: Reconstructing the History of Political Concepts and Languages In: MELCHING, W.; VELEMA, W. (Orgs.). Main Trends in Cultural History: Ten essays. Atlanta, GA: Rodopi, p.121-149, 1994

ROBINSON, N. The Genocide Convention: a commentary. New York: Institute of Jewish Affairs, World Jewish Congress, 1960

SALTER, M. B. Theory of the /: The Suture and Critical Border Studies. In: PARKER, N.; VAUGHAN-WILLIAMS, N. (Orgs). Critical Border Studies: Broadening and Deepening the 'Lines in the Sand' Agenda. New York: Routledge, p.8-29, 2014. 
SCHABAS, W. A. Genocide in International Law: The crime of crimes. 2 ed. New York: Cambridge University Press, 2009

Origins of the Genocide Convention: From Nuremberg to Paris. Case W.

Res. J. Int'l L. v.40, n.1, p.35-55, 2008

SEGESSER, D.; GESSLER, M. Raphael Lemkin and the international debate on the punishment of war crimes (1919-1948). Journal of Genocide Research. v.7, n.4, p.453-468, 2005

SHAPPIRO, M. J. Hiroshima Temporalities. Thesis Eleven. v.129, n.1, p.40-56, 2015

SHAW, M. Genocide and International Relations: changing patterns in the transitions of the late modern world. New York: Cambridge University Press, 2013

What is Genocide? 2 ed. Cambridge, UK: Polity Press, 2015

STRAUS, S. Contested meanings and conflicting imperatives: A conceptual analysis of genocide. Journal of Genocide Research. v.3, n.3, p.349-375, 2001

TOTTEN, S.; JACOBS, S. L. (Orgs). Pioneers of Genocide Studies. New Brunswick, N.J.: Transaction ublishers, 2002

UNITED NATIONS. Note to Correspondents: Statement by Adama Dieng, United Nations Special Adviser on the Prevention of Genocide on the situation in northern Rakhine State, Myanmar. New York, 29 Novembro 2016. Disponível em: < https://www.un.org/sg/en/content/sg/note-correspondents/2016-11-29/note-

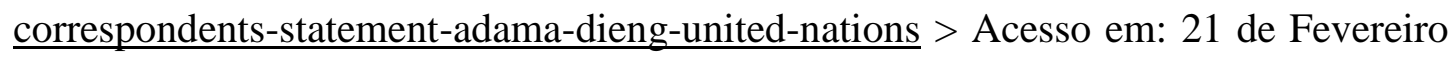
de 2017 às 15:43

UNITED STATES OF AMERICA. Department of State. Report of Robert H. Jackson United States Representative to the International Conference on Military Trials - London, 1945. Washington, D.C.: Division of Publications Office of Public Affairs, 1949.

VAUGHAN-WILLIAMS, N. International Relations and the 'Problem of History'. Millennium - Journal of International Studies. v.34, n.1, p.115-136, 2005

VERGNE, C. M. A Trama da Besta: a construção cotidiana do genocídio do negro no Rio de Janeiro. 2013. 124f. Tese (Doutorado em Psicologia). Departamento de Psicologia, Pontifícia Universidade Católica do Rio de Janeiro, 2013 
VILLAS BÔAS, L. Reinhart Koselleck (1923-2006). In: PARADA, M. (Org). Os Historiadores Clássicos da História: de Ricoeur a Chartier. Petrópolis: Editora Vozes, p.93-116, 2014 3v.

WAEVER, O. The Rise and Fall of the Inter-Paradigm Debate. In: SMITH, S.; BOOTH, K.; ZALEWSKI, M. (Orgs). International Theory: positivism and beyond. New York: Cambridge University Press, p.149-185, 1996

WALKER, R. B. J. History and Structure in the Theory of International Relations. Millennium - Journal of International Studies. v.18, n.2, p.163-183, 1989 . International/Inequality. International Studies Review. v.4, n.2, p.7-24, 2002

WATSON, A. The Evolution of International Society: a comparative historical analysis. New York: Routledge, 1992

WEITZ, E. D. The Modernity of Genocides: War, Race, and Revolution in the Twnetieth Century. In: GELlATELY, R.; KIERNAN, B. (Orgs). The Specter of Genocide: Mass murder in historical perspective. New York: Cambridge University Press, p.53-73, 2003

WIGHT, M. why is there no International Theory? International Relations. v.2, n.1, p.35-48, 1960

WOOLF, L. The Framework of a lasting peace. London:G. allen \& Unwin Ltd., 1917

ZAMMITO, J. Koselleck's Philosophy of Historical Time(s) and the Practice of History. History and Theory, v.43, n.1, p.124-135, 2004

ZIMMERN, A. The League of Nations and the rule of Law, 1918-1935. London: Macmillan, 1936 